University of Nebraska - Lincoln

DigitalCommons@University of Nebraska - Lincoln

9-4-2019

\title{
Little islands recording global events: late Quaternary sea level history and paleozoogeography of Santa Barbara and Anacapa Islands, Channel Islands National Park, California
}

Daniel R. Muhs

Lindsey T. Groves

Follow this and additional works at: https://digitalcommons.unl.edu/usgsstaffpub

Part of the Geology Commons, Oceanography and Atmospheric Sciences and Meteorology Commons, Other Earth Sciences Commons, and the Other Environmental Sciences Commons

This Article is brought to you for free and open access by the US Geological Survey at DigitalCommons@University of Nebraska - Lincoln. It has been accepted for inclusion in USGS Staff -- Published Research by an authorized administrator of DigitalCommons@University of Nebraska - Lincoln. 


\title{
Little islands recording global events: late Quaternary sea level history and paleozoogeography of Santa Barbara and Anacapa Islands, Channel Islands National Park, California
}

\author{
Daniel R. Muhs ${ }^{1, *}$ and Lindsey T. Groves ${ }^{2}$ \\ ${ }^{1}$ U.S. Geological Survey, MS 980, Box 25046, Federal Center, Denver, CO 80225 \\ ${ }^{2}$ Department of Malacology, Natural History Museum of Los Angeles County, 900 Exposition Blvd., Los Angeles, CA 90007
}

\begin{abstract}
Marine terraces are common on the Pacific Coast of North America and record interglacial high-sea stands superimposed on either stable or tectonically rising crustal blocks. Despite many years of study of these landforms in southern California, little work on terraces has been conducted on the two smallest of the California Channel Islands, Santa Barbara Island (SBI) and Anacapa Island (ANA). Presented here are new field and laboratory data on the ages, paleontology, and sea level history of marine terraces of these two islands. On both islands, the lowest marine terraces have shoreline angle elevations of $\sim 11 \mathrm{~m}$ above sea level. Amino acid geochronology shows that terrace deposits on both islands host fossils of two ages, one group dating to the $\sim 120$-ka high-sea stand and the other group likely dating to the $\sim 100$-ka high-sea stand. A mix of fossil ages is consistent with the paleontology as well, with SBI in particular showing a faunal assemblage that includes both extralimital southern and southward-ranging species (inferred to be from the 120-ka high-sea stand) and extralimital northern and northward-ranging species (inferred to be from the 100-ka high-sea stand). Fossil mixing from these two high-sea stands supports the hypothesis that glacial isostatic adjustment (GIA) processes have left a strong imprint on the geologic record of sea level history in southern California. Nevertheless, the elevations of these terraces and that of a low terrace on Santa Cruz Island indicate that modeled GIA estimates of paleo-sea level for the peak of the last interglacial period at $\sim 120 \mathrm{ka}$ could be too high. Future development of models of GIA effects on the Pacific Coast of North America will need to consider geologic records, such as those from SBI and ANA, in refining reconstructions of sea level history.
\end{abstract}

Resumen.-Las terrazas marinas son comunes en la costa del Pacífico de América del Norte, estas registran posiciones interglaciares superpuestas de alta mar, ya sea en bloques corticales estables o tectónicamente ascendentes. A pesar de muchos años de estudio de estos accidentes geográficos en el sur de California, se han realizado pocos estudios en las terrazas de las dos islas más pequeñas del Canal de California, la Isla Santa Bárbara y la Isla de Anacapa. En este estudio presentamos nuevos datos de campo y de laboratorio sobre las edades, la paleontología y la historia del nivel del mar de las terrazas marinas de estas dos islas. En ambas islas, las terrazas marinas más bajas presentan una elevación del ángulo de la línea de costa de $\sim 11 \mathrm{~m}$ sobre el nivel del mar. La geocronología de aminoácidos muestra que los depósitos de terrazas en ambas islas albergan fósiles de 2 edades: un grupo que data de $\sim 120$ ka y el otro grupo que probablemente data del 100-ka de altura del nivel del mar. Una mezcla de edades fósiles también es consistente con la paleontología de la Isla Santa Bárbara, en particular mostrando un ensamblaje faunístico que incluye tanto especies con distribuciones en los límites más sureños ( 120-ka de altura) y especies con distribuciones en los límites más norteños $(\sim 100$-ka de altura). La mezcla de fósiles de estos dos rodales de alta mar respalda la hipótesis de que los procesos de ajuste isostático glacial (GIA, por sus siglas en inglés) han dejado una fuerte huella en el registro geológico de la historia del nivel del mar en el sur de California. No obstante, las elevaciones de estas terrazas y de una terraza baja en la Isla Santa Cruz, indican que las estimaciones basadas en los GIA del nivel de paleo-mar, según el pico máximo del último período interglaciar de $\sim 120 \mathrm{ka}$, podrían ser demasiado elevadas. El desarrollo futuro de los modelos de efecto de los GIA en la costa del Pacífico de América del Norte necesitará considerar los registros geológicos, tales como los de la Isla Santa Bárbara y los de la Isla Anacapa, para perfeccionar la reconstrucción de la historia del nivel del mar.

AbBreviations.-AAL, Amino Acid Laboratory (University of Colorado, Boulder); ANA, Anacapa Island; CORS, Continuously Operating Reference Station; GIA, glacial isostatic adjustment; GPS, Global Positioning System; IPPC, Intergovernmental Panel on Climate Change; ka, kilo anno; LIG, last interglacial; MIS, marine isotope substage; LACM, Natural History Museum of Los Angeles Co.; NPS, National Park Service; ODP, Ocean Drilling Project; Qc, Quaternary coluvium; Qm, Quaternary marine terrace deposits; SBI, Santa Barbara Island; SLA, shoreline angle; SOPAC, Scripps Orbit and Permanent Array Center; SST, sea surface temperature or temperatures; Tv, Tertiary volcanic rocks; U-series, uranium-series.

*Corresponding author: dmuhs@usgs.gov

DRM

orcid.org/0000-0001-7449-251X

LTG

orcid.org/0000-0002-2097-2689 
With the prospect of a warmer Earth in the future, there is concern that polar ice sheets will lose mass and global sea level will rise. The latest Intergovernmental Panel on Climate Change (IPCC) report has identified some of the most important problems to investigate related to forecasting sea level change that is likely to occur within the near future (Church et al. 2013, Masson-Delmotte et al. 2013). One of these problems is identifying and understanding periods in the relatively recent geologic past when sea level was higher than the present. The period of time that has most commonly been studied for this is the peak of the last interglacial (LIG), known in the foraminiferal oxygen isotope record of deepsea cores as marine isotope substage (MIS) 5e (Shackleton and Opdyke 1973) or MIS 5.5 (Martinson et al. 1987). Based on uraniumseries (U-series) dating of corals from emergent marine deposits, MIS 5.5 occurred from $\sim 130 \mathrm{ka}(\mathrm{ka}=$ kilo anno $=1000$ years) to $\sim 115 \mathrm{ka}$ (see reviews in Muhs 2002, Dutton and Lambeck 2012, and Murray-Wallace and Woodroffe 2014). Uranium-series dating of corals from marine deposits of MIS 5.5 age has taken place both on tectonically active coasts such as southern California, including the Channel Islands (Muhs et al. 2002a, 2006, 2012, 2014a), and on tectonically stable coasts such as the Bahamas (Thompson et al. 2011), the Florida Keys (Muhs et al. 2011), Australia (O'Leary et al. 2013), and the Seychelles (Dutton et al. 2015). In tectonically stable regions, emergent marine deposits dating to MIS 5.5 are found above present sea level by amounts ranging from $\sim 3 \mathrm{~m}$ to $\sim 10 \mathrm{~m}$ (MurrayWallace and Woodroffe 2014). This implies that the mass of polar ice on the planet during MIS 5.5 was significantly less than at present, requiring smaller-than-present masses of the Greenland ice sheet, the West Antarctic ice sheet, or both. Because of this higher sea level, the LIG has been specifically identified by the IPCC as a possible analog to a future, higher sea level (Church et al. 2013, MassonDelmotte et al. 2013).

One potential challenge to the use of the LIG as an analog to a future Earth is the hypothesis that thermal expansion from warmer oceans could have played a role in the higherthan-present sea level at that time. This hypothesis can be tested using a variety of paleoclimate proxies from the marine record, including foraminifera, radiolarians, diatoms, coccoliths, and alkenones. Two studies using such proxy data from deep-sea cores have shown that on a global scale, average sea surface temperatures (SST) during the LIG were only slightly warmer than present (Turney and Jones 2010, McKay et al. 2011). However, the same studies showed that there were significant regional differences from the global average. Specifically, in the middle to high latitudes $\left(30^{\circ} \mathrm{N}\right.$ to $\left.70^{\circ} \mathrm{N}\right)$ of both the Atlantic Ocean and the Pacific Ocean, SST during the LIG may have been significantly warmer than present, by up to $\sim 4{ }^{\circ} \mathrm{C}$.

Paleoclimatic data from shallow marine invertebrate fossil records dated to MIS 5.5 support the reconstruction of warmer-thanpresent SST. Particularly important in this regard are extralimital species. Extralimital species are those taxa that in fossil form are found at localities well outside of their modern ranges. For the study areas considered here, these would be species that now live well to the north or south of Santa Barbara Island (SBI) and Anacapa Island (ANA). Extralimital species of mollusks and corals, indicating warmer SST during MIS 5.5, have been documented in the Indian Ocean along the western coast of Australia (Kendrick et al. 1991), around New Zealand and the southern coast of Australia (Murray-Wallace et al. 2000), along the Bering Sea and Arctic Ocean coasts of Alaska (Brigham-Grette and Hopkins 1995), in the eastern Atlantic Ocean and Mediterranean (Meco et al. 2002, Muhs et al. 2014c), in the Pacific Ocean along the shores of Oahu in the Hawaiian Islands (Kosuge 1969, Muhs et al. 2002b), along the central and southern California coast (Kennedy 2000, Muhs et al. 2002a, 2012, 2014a, 2014b), and in Baja California (Lindberg et al. 1980, Emerson et al. 1981). Thus, the importance of thermal expansion during the LIG may have been greater than the studies of Turney and Jones (2010) and McKay et al. (2011) imply.

On the California coast, LIG sea level history is more complicated than it is on many other coastlines. Although the peak of the LIG period is considered to be the high-sea stand at $~ 130-115 \mathrm{ka}$, there were two younger high-sea stands during MIS 5, at $\sim 100 \mathrm{ka}$ and $\sim 80 \mathrm{ka}$. These two younger high-sea stands are represented by uplifted coral reef terraces on a number of tropical coastlines, 
such as Barbados, Haiti, and New Guinea (Broecker et al. 1968, Mesolella et al. 1969, Bloom et al. 1974, Dodge et al. 1983, Gallup et al. 1994, Edwards et al. 1997). They are also apparent in the oxygen isotope record of foraminifera recovered from deep-sea cores as MIS 5c (or 5.3) at $\sim 100 \mathrm{ka}$ and MIS 5a (or 5.1) at $\sim 80 \mathrm{ka}$ (Shackleton and Opdyke 1973, Martinson et al. 1987). Erosional marine terraces of these younger high-sea stands are also represented in the geologic record of coastal California and Baja California (Kennedy et al. 1982, Rockwell et al. 1989, Muhs et al. 1994, 2002a, 2006, 2012, 2014a, 2015). Based on such records, however, the apparent sea level history of the Pacific Coast of North America differs from that obtained from coastlines in the tropics.

Large ice sheets that covered much of North America during the most recent glacial periods exerted powerful effects on the continental crust and lithosphere of North America and the surrounding oceans. These processescollectively referred to as glacial isostatic adjustment (GIA) effects-include changes in the direct gravitational attraction of the timevarying ice-plus-ocean load and perturbations in both crustal and sea-surface heights in response to load-induced deformation (Mitrovica and Peltier 1991, Mitrovica and Milne 2002, Potter and Lambeck 2004, Milne and Mitrovica 2008, Tamisiea and Mitrovica 2011). The cumulative result of these processes is that apparent sea level history, based on geologic records such as marine terraces, will differ from coast to coast depending on proximity to large ice sheets. In North America, GIA effects are significant because the Laurentide and Cordilleran ice sheets covered much of the continent during the last glacial period and previous glacial periods. Glacial isostatic adjustment effects on apparent sea level will generate a geologic record that departs from a purely eustatic one most dramatically on coastlines near such ice sheets ("near-field" localities or "intermediate-field" localities, such as California), whereas coastlines distant from ice sheets ("far-field" localities, such as Barbados and New Guinea) will record a more purely eustatic sea level history. A combination of field studies and modeling shows that GIA effects have been important on the Pacific Coast of North America (Muhs et al. 2012, Clark et al. 2014, Creveling et al. 2015,
2017, Reeder-Meyers et al. 2015, Simms et al. 2016).

Although SBI and ANA are by far the smallest of the California Channel Islands (Fig. 1), previous studies have shown that their coastlines host multiple marine terraces that are fossiliferous (Scholl 1960, Valentine and Lipps 1963, Lipps 1964, Lipps et al. 1968). The presence of fossils means that these terraces have the potential to be dated and thus can be compared to the late Quaternary sea level record. Marine fossils also have the potential for reconstruction of past SST using paleozoogeographic interpretations. Previous work on SBI and ANA by the investigators cited above indicates that the fossil assemblages are largely from what were rocky intertidal marine environments. In assessing the paleozoogeographic aspects of such assemblages, it is uncommon for investigators to make comparisons to fossil assemblages of the same age from protected, quiet-water ("bay") environments where different marine invertebrate taxa thrive. Thus, it can be hypothesized that paleoclimatic interpretations could differ from one marine environment to another. In order to investigate this issue further, a locality relatively close to SBI and ANA was sought where a protected, quietwater fossil assemblage that is likely the same age might be studied. Fossil marine deposits found in San Pedro, California (Fig. 1) fit these requirements, based on previous work by Woodring et al. (1946). Finally, little work has been done on the western end of neighboring Santa Cruz Island, although terraces have been mapped there (Pinter et al. 1998, 2003). Therefore, reconnaissance work was also conducted in the Fraser Point area of westernmost Santa Cruz Island, complementary to the studies on the two smaller islands. Indeed, the Fraser Point area of Santa Cruz Island was likely a small island itself during the LIG.

Given the overall low uplift rates reported for many of the other California Channel Islands (Muhs et al. 2012, 2014a), it is hypothesized that low-elevation terraces on SBI, ANA, and Santa Cruz Island likely date to some part of the LIG complex, MIS 5. It is further hypothesized that given the previous studies showing a complex history of MIS $5.5,5.3$, and 5.1 (equivalent to MIS 5e, 5c, and $5 \mathrm{a}$, respectively, of Shackleton and Opdyke 1973) as seen in the marine terrace record elsewhere on the California coast 

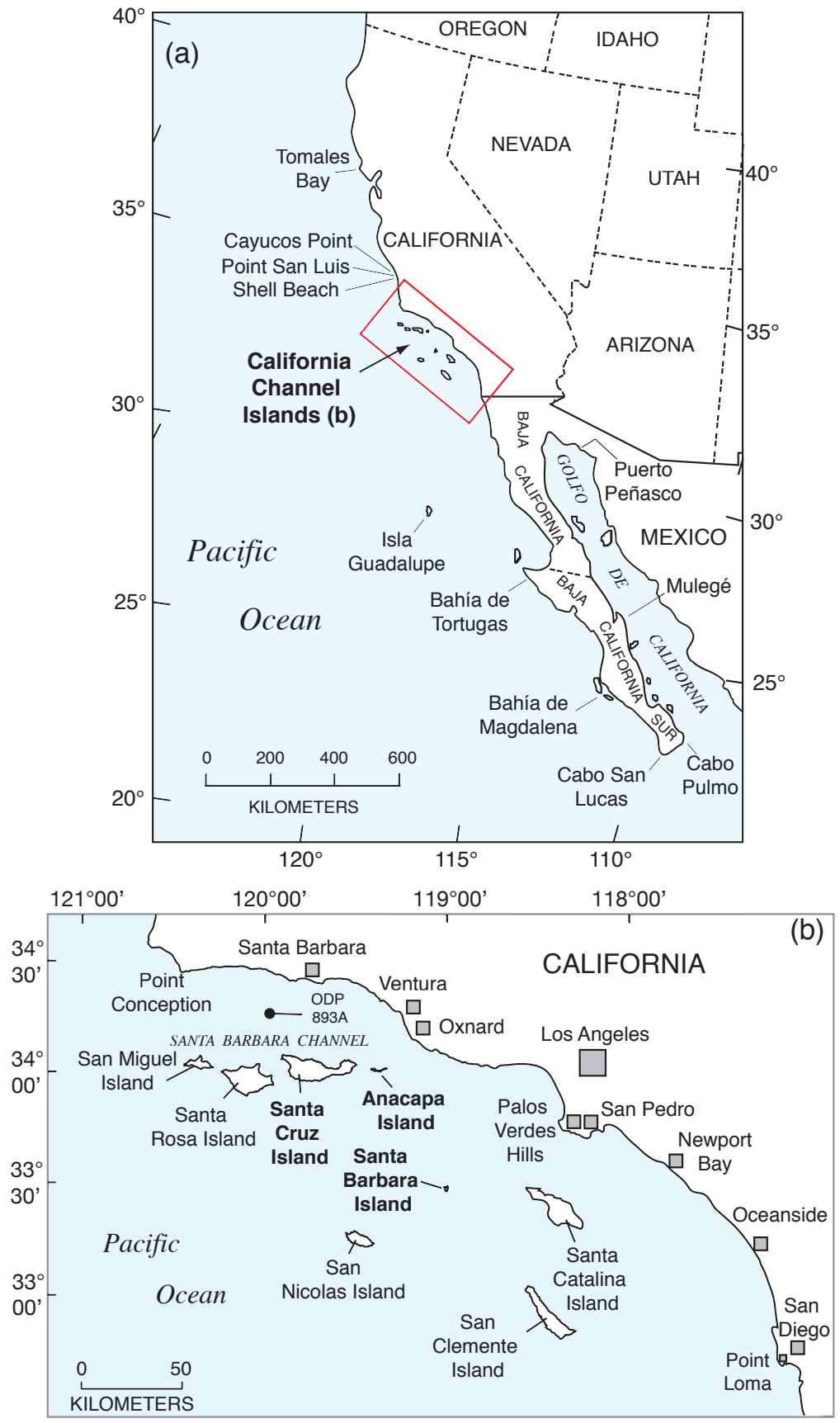

Fig. 1. (a) Map of southwestern North America. The red box outlines the location of the California Channel Islands. (b) Map showing the California Channel Islands. Islands with names in bold (Santa Cruz Island, Anacapa Island, and Santa Barbara Island) are the primary focus of the present study. ODP 893A = Ocean Drilling Project site 893A.

(Muhs et al. 2002a, 2012, 2014a, 2014b), there could be a similarly complex history recorded in the terraces and their fossils on these small islands. To test these hypotheses in the present effort, field and laboratory studies were conducted, including terrace mapping and elevation measurements, geochronology of fossils from the terraces, and 


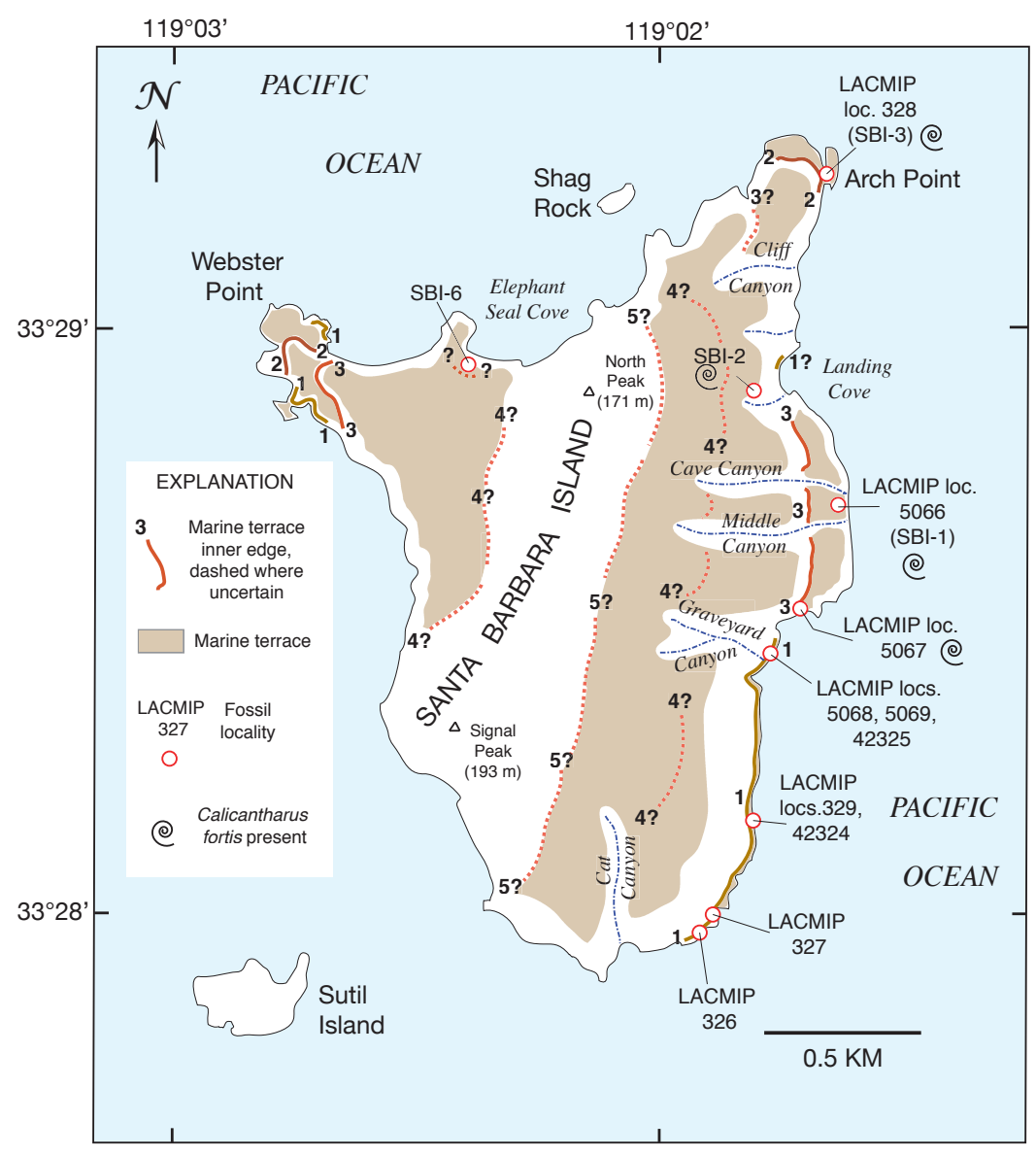

Fig. 2. Map showing the distribution of marine terraces, terrace inner edges, and fossil localities on Santa Barbara Island, California. Marine terraces were mapped in the field by the authors using a topographic map and stereoscopic aerial photography from the National Oceanic and Atmospheric Administration. Base map is from the U.S. Geological Survey, Channel Islands National Monument, California, topographic map (1973), contour interval 40 feet (12.2 m); scale 1:24,000.

paleontology and paleozoogeography of the fossil assemblages.

\section{Methods}

Field and GPS Methods

Marine terraces were mapped in the field on SBI. The spatial extent of these units was determined by initial mapping on aerial photographs and topographic maps, refined by field examination of terrace geomorphology, exposures in sea cliffs, and outcrops in shorenormal-trending canyons (Fig. 2). On Middle Anacapa Island, Scholl (1960) previously mapped marine terrace deposits, and field studies herein agree with his mapping. Thus, the marine terrace map presented for this island (Fig. 3) is reproduced largely from his work, with modest additions. Possible marine terraces on East Anacapa Island and West Anacapa Island were identified by old, highelevation but low-relief surfaces with gentle seaward slopes, identifiable in the field and on aerial photographs and topographic maps that lack definitive evidence of marine deposits (rounded, pholad-bored gravels and marine fossils). These surfaces are sometimes backed on their landward margins by what appear to be paleo-sea cliffs and have platforms that dip gently seaward, interpreted as wave-cut benches. The platforms have elevations that are concordant from island to island or with other low-relief surfaces bounded by adjacent drainages. On some of these surfaces, Johnson 


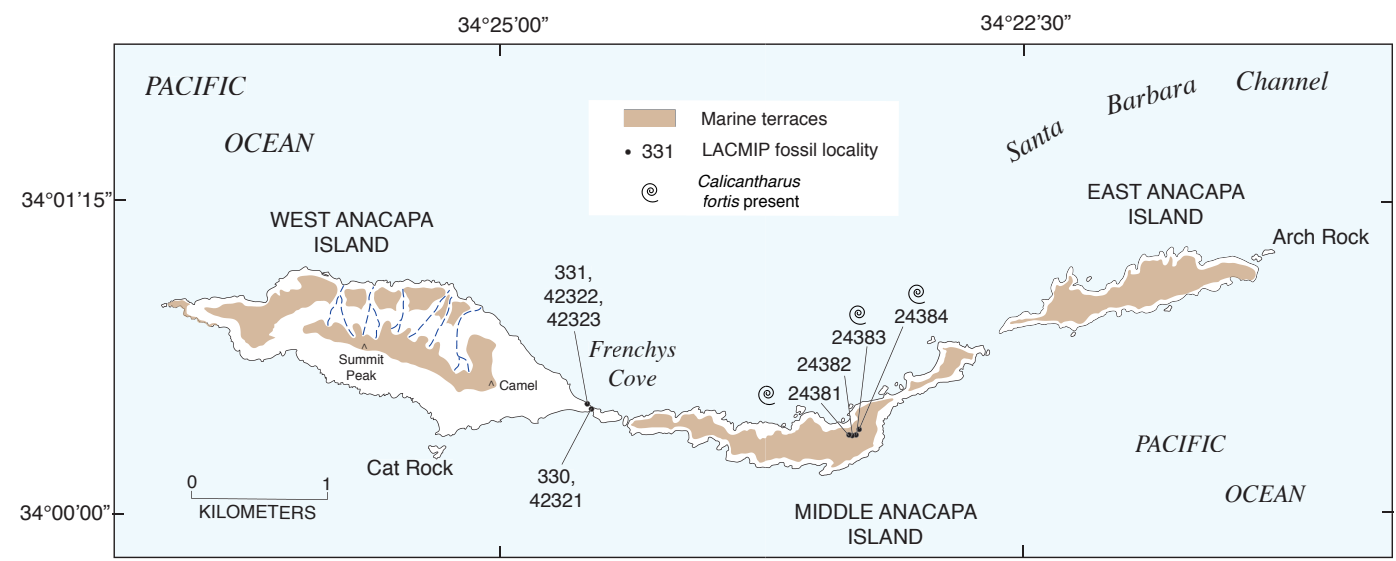

Fig. 3. Map showing the distribution of marine terraces and fossil localities on the Anacapa Islands, California. Marine terraces were mapped by the authors using a topographic map and stereoscopic aerial photography from the U.S. Geological Survey (National Aerial Photography Program photographs; 1:40,000 scale). Base map is from the U.S. Geological Survey, Channel Islands National Monument, California, topographic map (1973), contour interval 40 feet (12.2 m); scale 1:24,000.

(1979) reported the occurrence of marine terrace sediments, supporting such an origin.

In addition to mapping terrace boundaries, accurate and precise determinations of the elevations of geomorphic features that mark past sea levels are critical to the present work. On high-wave-energy coastlines such as California, the best paleo-sea level indicator is the shoreline angle, defined as the junction of the wave-cut platform and the former sea cliff found at the landward edge of the wave-cut platform (see Fig. 2 in Muhs et al. 2004). Some examples of shoreline angles of emergent marine terraces on ANA and SBI are shown in Fig. 4. Elevations of most localities studied were determined using differential Global Positioning System (GPS) measurements. Latitude/longitude data and elevations were ascertained using a portable differential GPS instrument connected to a handheld computer. At each location, data were collected from at least four satellites (and usually six to eight) for at least $500 \mathrm{~s}$ to obtain consistent 3D geometry. The data were post-processed using Trimble ${ }^{\circledR}$ GPS Pathfinder ${ }^{\circledR}$ Office software in which GPS field data were differentially corrected against five to eight base stations in the Continuously Operating Reference Station (CORS; Strange and Weston 1997) and Scripps Orbit and Permanent Array Center (SOPAC; Bock et al. 1997) networks, located within $200 \mathrm{~km}$ of the study areas. A comparison of GPS-derived elevations with benchmarks and taped eleva- tions shows good agreement, within the limits of instrumental uncertainty $(<0.5 \mathrm{~m})$. In a few localities topographic barriers did not permit good satellite geometry. Where this was a problem, elevations were measured with a hand level and tape and tied to GPS locations where satellite geometry was favorable.

\section{Amino Acid Geochronology/ \\ Aminostratigraphy of Marine Terrace Mollusks}

Uranium-series geochronology yields numerical ages of terrace fossils, but this method requires corals, which are among the few marine invertebrates that incorporate uranium from seawater into their skeletons during growth. No corals were found in the deposits on ANA and only a few corals were recovered on SBI and Santa Cruz Island. Uranium-series dating of corals from the latter two islands is still in progress. Although mollusks cannot be used for U-series dating, there is an alternative method available for these organisms that yields relative or correlated ages. Amino acid dating of fossil mollusks from emergent marine deposits is an important geochronological tool in marine terrace studies, and detailed reviews can be found in Wehmiller (1982, 1992, 2013a, 2013b) and Miller et al. (2013). The technique is based on the conversion of $\mathrm{L}$ enantiomers of amino acids to D enantiomers-a process called racemization-after the death of an organism. For this purpose the 


\section{(a) Santa Barbara Island}

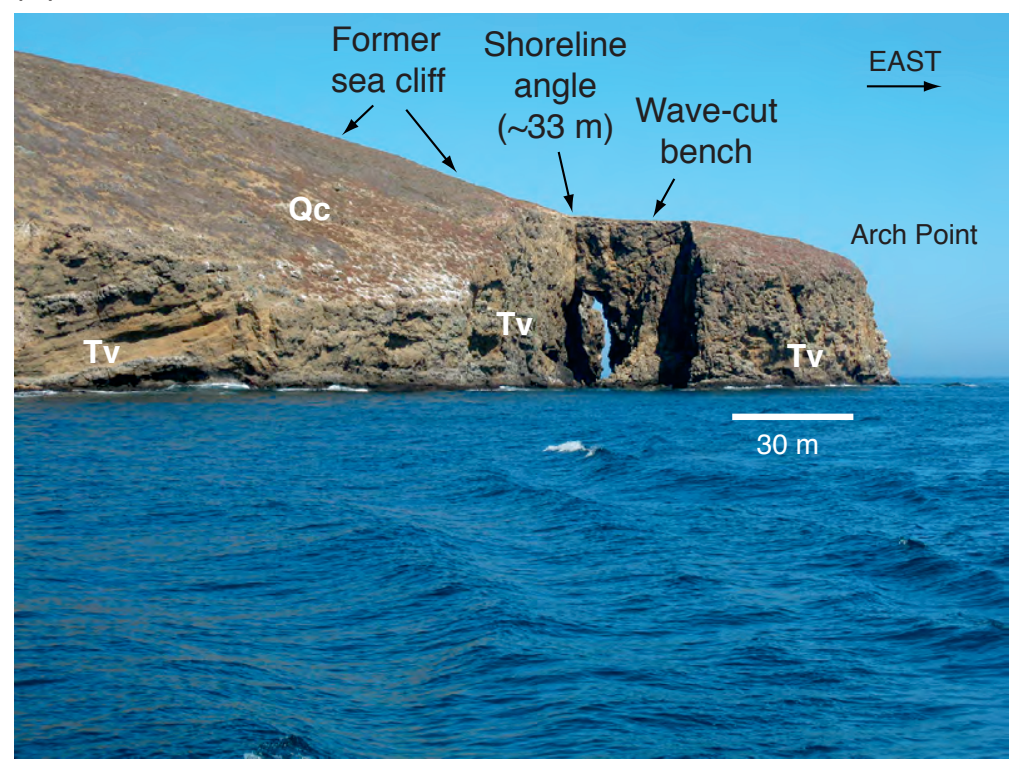

(b) East Anacapa Island

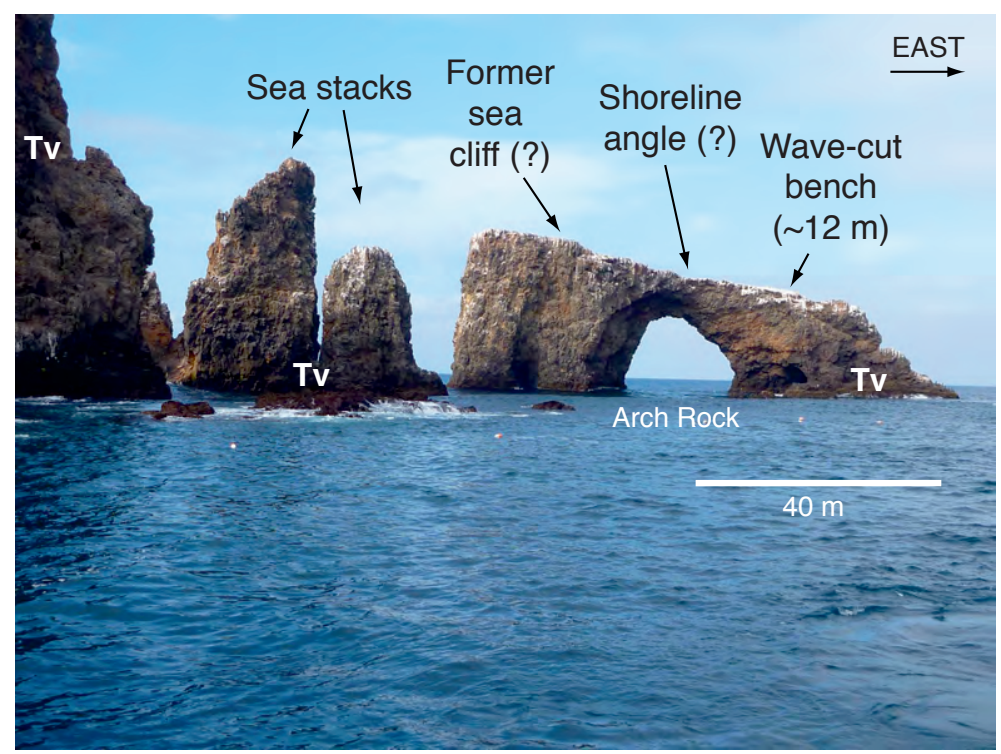

Fig. 4. Photographs of marine terraces on (a) Santa Barbara Island and (b) East Anacapa Island. Photographs were taken offshore and show examples of shoreline angles, former sea cliffs, and wave-cut benches. Qc = Quaternary colluvium, $\mathrm{Tv}=$ Tertiary volcanic rocks. Photographs by D.R. Muhs.

present study utilizes the common rocky intertidal gastropod Chlorostoma (formerly Tegula [McLean 2007]), usually Chlorostoma funebralis (Adams 1855); the bivalve Epilucina californica (Conrad 1837); and species of the bivalve Chione (C. californiensis, C. undatella, and C. fluctifraga). Previous studies have shown that Chlorostoma is a reliable genus for amino acid geochronology, while Epilucina is perhaps not quite as robust an age indicator (Wehmiller et al. 1977, Muhs, 1983, 1985, Muhs et al. 1992, 2014a). The general reliability of 
these two genera is demonstrated later in this paper. There are fewer data available for Chione, but based on analyses of coexisting specimens, Wehmiller et al. (1977) note that fossil Chione has D/L values similar to coexisting fossil Leukoma (formerly Protothaca) and Saxidomus, two genera that have been utilized extensively on the Pacific Coast of North America for amino acid geochronology (Kennedy et al. 1982, Wehmiller 1982, 1992, 2013a, 2013b).

Relative abundances of $\mathrm{D}$ and $\mathrm{L}$ enantiomers of the amino acids valine and glutamic acid were measured in fossil specimens of these genera using reverse-phase liquid chromatography (Kaufman and Manley 1998) at the Amino Acid Laboratory (AAL) of the University of Colorado, Boulder. Interlaboratory comparisons of this facility's results with others can be found in Wehmiller (2013c). Ratios of D to $\mathrm{L}$ values for valine and glutamic acid were measured using peak heights. A comparison of $\mathrm{D} / \mathrm{L}$ values computed by both peak heights and peak areas by Muhs et al. (2014a) for Chlorostoma and Epilucina and by Muhs et al. (2018) for Callianax shows no significant differences. Nevertheless, somewhat better run-to-run agreement was achieved with peak-height ratios. Therefore, this method was used in the present study for $\mathrm{D} / \mathrm{L}$ values in both glutamic acid and valine.

In addition to the racemization of $\mathrm{L}$ enantiomers of amino acids to D enantiomers, another process that occurs after the death of an organism is epimerization of L-isoleucine to D-alloisoleucine; thus, ratios of D-alloisoleucine to L-isoleucine are complementary to $\mathrm{D} / \mathrm{L}$ values of other amino acids. Peak heights of Dalloisoleucine to L-isoleucine in Chlorostoma and Chione fossils from ANA, SBI, and other localities were also measured. Many of the ratios of these two amino acids were also measured by reverse-phase liquid chromatography, as above, but older data used here, reported by Muhs (1985) and Muhs et al. (1992), were measured by conventional liquid chromatography (Miller 1985). Measurements of Dalloisoleucine to L-isoleucine by the two methods give comparable results. Peak-height ratios for all new analyses of individual shells (as well as geographic, geologic, and other documentary information) are tabulated in Appendixes $1,2,3$, and 4 .

Amino acid racemization and epimerization are temperature-dependent processes, with lower rates occurring in cooler climates (Wehmiller 1982, 2013a, 2013b, Wehmiller and Miller 2000, Miller et al. 2013). In comparing amino acid data from fossil mollusks of the Channel Islands, D/L values were measured in Chlorostoma and Epilucina fossils and compared to similar ratios in specimens from other dated marine terrace localities in California and Baja California. These collections were made from localities along a roughly northwest-southeast temperature gradient from central California to northern Baja California (slightly modified from Fig. 3 of Muhs et al. 2014a). The localities host deposits containing corals that have been dated independently through U-series methods to $\sim 80 \mathrm{ka}$ (MIS 5.1) and either $\sim 120 \mathrm{ka}$ (MIS 5.5) or a mix of $\sim 100 \mathrm{ka}$ (MIS 5.3 ) and $\sim 120 \mathrm{ka}$ (MIS 5.5) ages, based on studies by Muhs et al. (1994, 2002a, 2006, 2012, 2014a, 2015). For values of $\mathrm{D}$-alloisoleucine to $\mathrm{L}$-isoleucine in Chione fossils of unknown age (from ANA, San Pedro, and Puerto Peñasco), we also measured similar ratios in Chione fossils from marine deposits that were independently dated.

Under favorable conditions, $\mathrm{D} / \mathrm{L}$ values of amino acids or values of $\mathrm{D}$-alloisoleucine/ L-isoleucine in shells from deposits of the same age show northward-decreasing values along a north-to-south-trending coastline (in the Northern Hemisphere). This trend, when presented graphically $(\mathrm{D} / \mathrm{L}$ values vs. latitude or temperature), forms an isochron line or band called an "aminozone" (see examples in Kennedy et al. 1982, Wehmiller 1982, MurrayWallace et al. 2000, Muhs et al. 2014a). Shells of younger deposits should yield a parallel or subparallel aminozone line or band of $\mathrm{D} / \mathrm{L}$ values below those defined by an older suite of shells. Thus, D/L values in shells of a deposit of unknown age can be plotted on such latitudinal arrays for the purpose of correlation to independently dated deposits. Deviations from this idealized trend can be due to a variety of factors, including different burial depths (and therefore variable thermal histories), reworking of older fossils, and exchange of amino acids from through-flowing soil or sediment pore waters (Wehmiller et al. 1977, Wehmiller 1982, 2013a, 2013b, Kosnik and Kaufman 2008). The potential of such problems in the present study was assessed using methods outlined in Kosnik and Kaufman (2008). 


\section{Paleontology and Paleozoogeography}

Fossils collected on SBI and ANA were identified at the Natural History Museum of Los Angeles County (LACM), California, which hosts an extensive reference collection of modern and fossil marine invertebrates from the eastern Pacific Ocean. Paleozoogeographic reconstructions are based on comparisons with the modern ranges of the taxa identified because all of the species examined (with one exception, Calicantharus fortis) are extant forms. Of particular significance in paleoclimatic interpretations is the presence of extralimital taxa (i.e., species that now live well to the north or south of SBI and ANA). In addition to strictly extralimital taxa, paleoclimatic interpretations can also be based in part on species whose range endpoints occur at or near the two islands. Such taxa are referred to as northward-ranging or southward-ranging forms. Thus, a southward-ranging taxon may presently live at or around a given study locality but is found no farther north. Determination of whether species are extralimital, northward-ranging, or southward-ranging is based on modern geographic distributions of these taxa from collections in the Malacology Section of the LACM. In addition, the following sources were also used for this purpose: Coan et al. (2000) and Coan and Valentich-Scott (2012) for bivalves; Keen (1971), Abbott (1974), McLean (1978, 2007), Abbott and Haderlie (1980), and Bertsch and Aguilar Rosas (2016) for gastropods; and Haderlie and Abbott (1980) and Eernisse et al. (2007) for polyplacophora.

\section{RESULTS}

\section{Marine Terraces on Santa Barbara Island}

Santa Barbara Island is composed almost completely of mafic volcanic rocks (Norris 1991, Dibblee 2001). Chemical analyses presented by Weigand et al. (1998), Weigand and Savage (2002), and Muhs et al. (2008) show that the rocks vary in composition from basalt to basaltic andesite. A whole-rock ${ }^{40} \mathrm{Ar} / 39 \mathrm{Ar}$ age from basalt on SBI is $15.5 \pm 1.0 \mathrm{Ma}$ (Luyendyk et al. 1998) and confirms the interpretation of earlier researchers that the rocks are of Miocene age. Some of the rocks are vesicular pillow basalts; the pillow structure indicates that the eruptions that formed the rocks occurred under water (Norris 1991, Dibblee 2001).
In six trips to SBI, marine terraces were mapped, terrace elevations were measured, and terrace fossils were collected. Lipps et al. (1968) reported that there may be as many as six terraces on the island, although one of these is found at an elevation of $\sim 1.5 \mathrm{~m}$ and could be simply a storm bench. These investigators also reported higher terraces at elevations of $\sim 7-8 \mathrm{~m}, \sim 15 \mathrm{~m}, \sim 40 \mathrm{~m}$, and $\sim 76 \mathrm{~m}$. In the present study, evidence was found for at least four and possibly five marine terraces on SBI. The lower three terraces have shoreline angles exposed near Webster Point, as illustrated by Lipps et al. (Fig. 3 in Lipps et al. 1968) and observations presented here (Fig. 5a). The lowest terrace at Webster Point has a shoreline angle elevation of $11 \mathrm{~m}$. What is interpreted to be the outer edge of the same terrace is exposed on the eastern side of the island between Graveyard Canyon and Cat Canyon (Figs. 2, 5b). At this locality, the shoreline angle is exposed but inaccessible (Fig. 5b), and the outer edge of the wave-cut bench has an elevation of $4.3 \mathrm{~m}$. The second terrace in the Webster Point area (Fig. 5a) has a shoreline angle elevation of $\sim 30 \mathrm{~m}$; what is interpreted to be the same terrace has a shoreline angle elevation of $\sim 33 \mathrm{~m}$ at Arch Point (Fig. 4a). The third terrace has a shoreline angle elevation between $\sim 44 \mathrm{~m}$ (highest bench) and $\sim 51 \mathrm{~m}$ (lowest cliff) at Webster Point and an elevation of $49.4 \mathrm{~m}$ on the eastern side of the island where it is exposed in the walls of Cave Canyon (Fig. 2). The shoreline angle of the fourth terrace is exposed in the sea cliff on the western side of the island $\sim 1 \mathrm{~km}$ southeast of Webster Point. The precise location of the shoreline angle, while visible, is inaccessible, but about two-thirds of the way down the colluvial wedge that covers it, an approximate elevation of $82 \mathrm{~m}$ was measured, a maximumlimiting estimate. The outer edge of the terrace has an elevation of $\sim 66 \mathrm{~m}$, a minimum figure, so the shoreline angle must lie at an elevation between these two values and is probably closer to the maximum figure. On the eastern side of the island, what is interpreted to be an outer bench of the fourth terrace with overlying, fossiliferous marine deposits (SBI-2 on Fig. 2) has an elevation of $68 \mathrm{~m}$. Finally, what is interpreted as a former sea cliff extends north to south, parallel to the long axis of the island. The inner edge of a probable fifth terrace may lie just to the east of this 

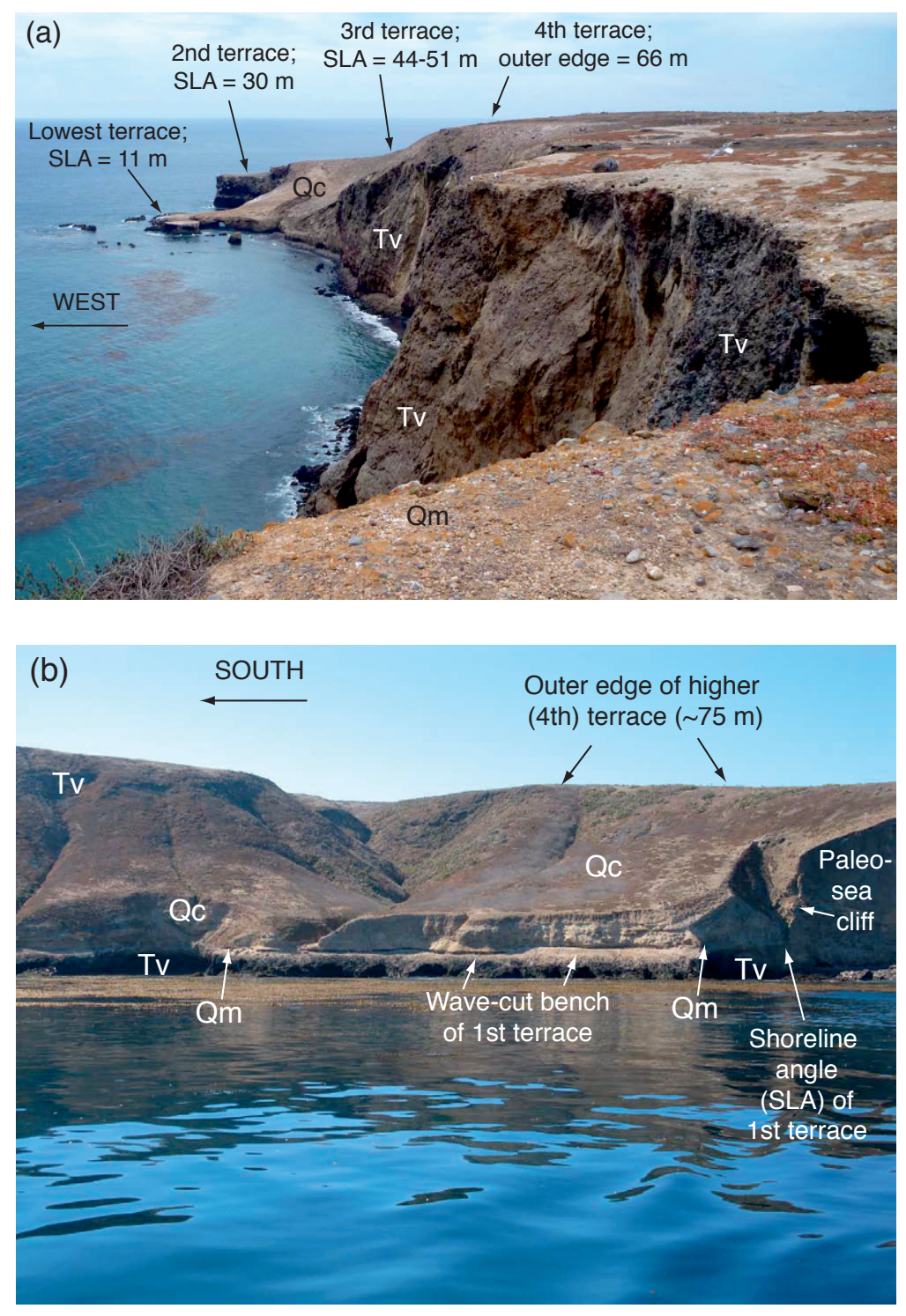

Fig. 5. Marine terraces on Santa Barbara Island. (a) The lowest four terraces in the Webster Point area (see Fig. 2 for location); shoreline angle elevations were measured by differential GPS (this study). Compare to Fig. 3 of Lipps et al. (1968). (b) View of the first terrace and outer edge of a higher terrace looking west from offshore, near Graveyard Canyon (see Fig. 2 for location). Tv = Tertiary volcanic rocks (mainly basalt), Qm = Quaternary marine terrace deposits, $\mathrm{Qc}=$ Quaternary colluvium, and SLA = shoreline angle. Photographs by D.R. Muhs.

former sea cliff (Fig. 2). No shoreline angles for this terrace were observed, but the inner edge lies at an elevation of $\sim 120 \mathrm{~m}$ where it was measured. This is clearly a maximum elevation for the possible terrace because the measurements were taken on the surface of a colluvial wedge of unknown thickness that covers the bench and shoreline angle. Thus, we recognize at least four certain terraces with shoreline angle elevations of $11 \mathrm{~m}, 30-33 \mathrm{~m}$, 44-51 m, and 66-82 m, with a probable fifth terrace at some elevation between perhaps 100 and $120 \mathrm{~m}$. Fossiliferous marine deposits (Fig. 2) overlie the first terrace $(11 \mathrm{~m})$ on the southeastern side of the island (LACMIP localities [locs.] 326, 327, 329 [= LACMIP loc. 42324], 5068 [= LACMIP loc. 42325]), the second terrace (30-33 m) at Arch Point 
(LACMIP loc. 328), on the outer edge of the third terrace $(49 \mathrm{~m})$ between Cave Canyon and Middle Canyon and between Middle Canyon and Graveyard Canyon (LACMIP locs. 5066 and 5067), and on the outer edge of the fourth terrace $(\sim 68 \mathrm{~m})$ above Landing Cove (SBI-2 on Fig. 2).

\section{Marine Terraces on Anacapa Island}

Anacapa Island actually consists of three small islets (East, Middle, and West Anacapa) separated by very shallow gaps (Fig. 3). Volcanic rocks dominate the bedrock of all three islands (Norris 1995). Mapping by Scholl (1960) and Dibblee (2001) indicates that the rocks consist of the Santa Cruz Island Volcanics and/or the Conejo Volcanics units of middle Miocene age. Geochemistry reported by Muhs et al. (2008) indicates that the rocks on East Anacapa Island are andesites and basaltic andesites. On Middle and West Anacapa Islands there are also beds of the San Onofre Breccia (Norris 1995). Muhs et al. (2008) also report very small outcrops of San Onofre Breccia exposed on the west side of Cathedral Cove on East Anacapa Island. This unit contains clasts of quartzite or vein quartz, blueschist, shale, and sandstone. Luyendyk et al. (1998) report ${ }^{40} \mathrm{Ar} /{ }^{39} \mathrm{Ar}$ ages on plagioclase separates from ANA rocks of $16.2 \pm 0.2 \mathrm{Ma}$ and $16.3 \pm 0.2 \mathrm{Ma}$, confirming the Miocene age assignments of Scholl (1960), Lipps (1964), and Norris (1995).

Scholl (1960) recognized two marine terraces on the Anacapa Islands. The highest one was recorded at $\sim 183 \mathrm{~m}$ on West Anacapa and the lower one was at $\sim 76 \mathrm{~m}$ on Middle and East Anacapa. Fossils are abundant in the deposits of the 76-m terrace on Middle Anacapa Island and were studied by Valentine and Lipps (1963). Miller et al. (1961) reported a lower terrace on West Anacapa, estimated to be $\sim 8 \mathrm{~m}$ above sea level. Lipps (1964) studied the deposits and fossils of this terrace and reported about a dozen species, two of which are southward-ranging taxa. Johnson (1979) confirmed the fossiliferous deposits on the 76-m terrace on Middle Anacapa and the 8-m terrace on West Anacapa. In addition, Johnson (1979) reported that nonfossiliferous marine deposits are found at the highest elevations of West Anacapa near Camel Peak ( 247 m) and Summit Peak $(\sim 285 \mathrm{~m})$, but these occurrences have not been confirmed in the present study.
Pinter et al. (2003) reported new elevation measurements of some of the higher terraces on all three of the Anacapa Islands.

During eight trips to the Anacapa Islands, the marine terraces and their deposits and fossils were studied. The likely extent of marine terraces on the three islands (Fig. 3) was determined using interpretation of stereo aerial photographs and topographic maps, as well as field observations; we stress that these are approximations because marine terrace exposures are few. East Anacapa Island has a mesalike appearance and has likely been shaped almost entirely by marine terrace formation. The andesite bedrock of East Anacapa is also cut by a number of faults. Sea caves, surge channels (a shore-normal channel cut into bedrock by waves), and arches have formed where these faults occur. Marine terrace exposures on East Anacapa Island are rare, but based on the topography of the surface of the island, more than one terrace may be present. Wave-cut benches are visible in sea cliff and surge channel exposures with their outer edges on the northern side of the island ranging in elevation from $\sim 36 \mathrm{~m}$ to $\sim 60 \mathrm{~m}$. The eastern side of Arch Rock may consist of a highly degraded marine terrace, with a shoreline angle at $\sim 12-14 \mathrm{~m}$ backed by a sea cliff rising to $\sim 25 \mathrm{~m}$ (Fig. 4b). On Middle Anacapa Island, two marine terraces were identified. The higher terrace, also recognized in previous studies, forms much of the upland topography of Middle Anacapa Island; this terrace has an outer bench elevation of $\sim 70 \mathrm{~m}$ and is overlain by marine and nonmarine deposits up to an elevation of $83 \mathrm{~m}$ (Fig. 6a). Although Scholl (1960), Miller et al. (1961), and Lipps (1964) did not report a low-elevation terrace on Middle Anacapa Island, one was observed in the present study with an outer bench elevation of $\sim 4 \mathrm{~m}$ to $\sim 5 \mathrm{~m}$ and an estimated inner edge elevation of perhaps 10 to $11 \mathrm{~m}$ (Fig. 6a). Marine terrace deposits on this bench are $\sim 0.5 \mathrm{~m}$ thick and are overlain by several meters of colluvium. The colluvium is undated but is likely of late Pleistocene age, based on the presence of abundant bones from the extinct flightless goose Chendytes lawi in similar colluvium overlying the low-elevation bench on West Anacapa Island (Miller et al. 1961, Lipps 1964).

The low terrace on Middle Anacapa Island can be traced discontinuously to West Anacapa Island where it is prominently displayed at 
(a)

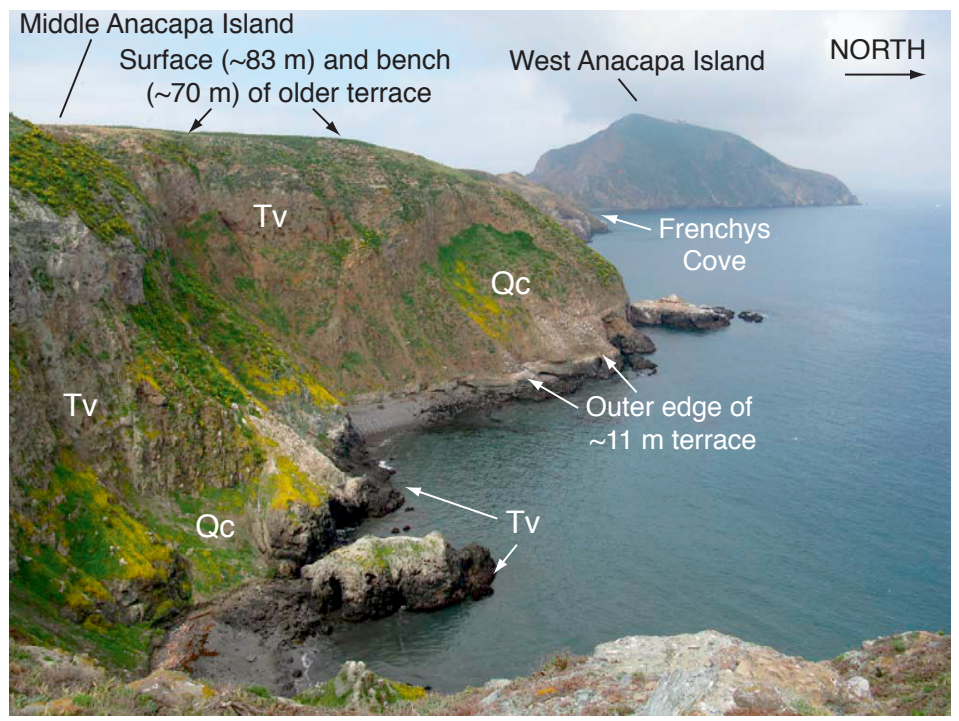

(b)

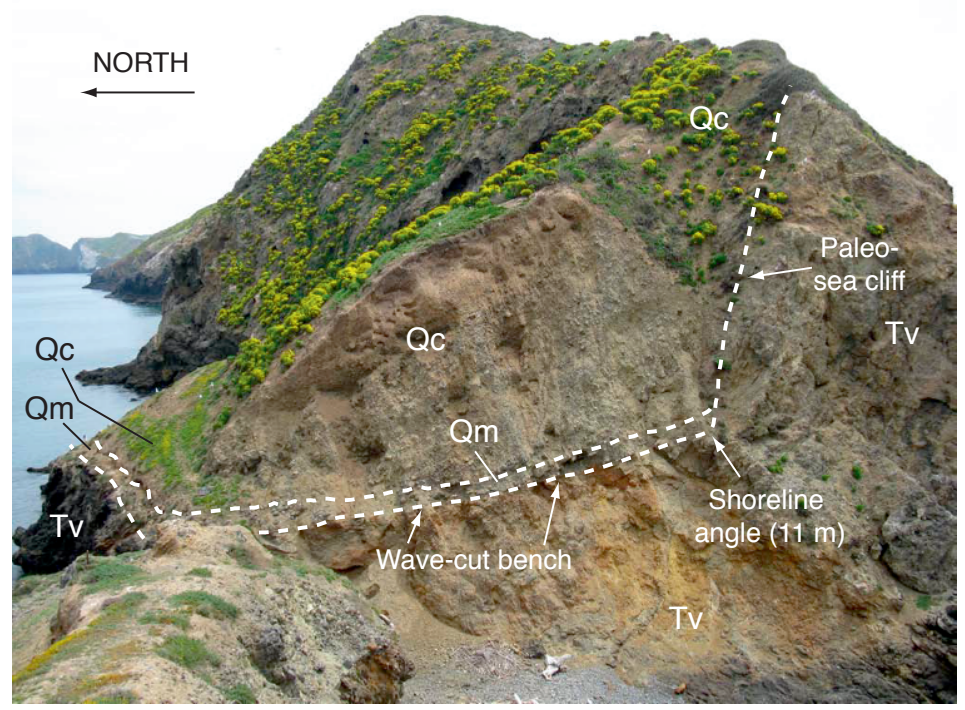

Fig. 6. Marine terraces on the Anacapa Islands. (a) View to the west from Middle Anacapa Island showing 11-m and $\sim 70-\mathrm{m}$ terraces on the island; West Anacapa Island is visible in the background. (b) View looking east on West Anacapa Island, near LACMIP loc. 331, showing Tertiary bedrock, wave-cut bench, shoreline angle, marine terrace deposits, and colluvium. Compare to Fig. 3 of Lipps (1964). Tv = Tertiary volcanic rocks (mainly andesite), Qm = Quaternary marine terrace deposits, and Qc $=$ Quaternary colluvium. Photographs by D.R. Muhs.

Frenchys Cove, the locality studied by Lipps (1964). On West Anacapa Island, the shoreline angle of this low terrace is exposed at an elevation of $11 \mathrm{~m}$ (Fig. $6 \mathrm{~b}$ ). The marine terrace deposits here are overlain by thick deposits of colluvium (Fig. 6b; see also Fig. 3 of Lipps 1964), as is the case on Middle Anacapa Island. Curiously, there is no apparent source for this colluvium at present because the uppermost part of the colluvial wedge is near the summit of this part of the island. This is interpreted to mean that much of the island that once existed landward (i.e., southward) and above this marine terrace has been eroded since terrace formation and emergence. Fossils are rare in the marine terrace deposits on the 11-m terrace shown in Fig. $6 \mathrm{~b}$ but are abundant in laterally traceable 


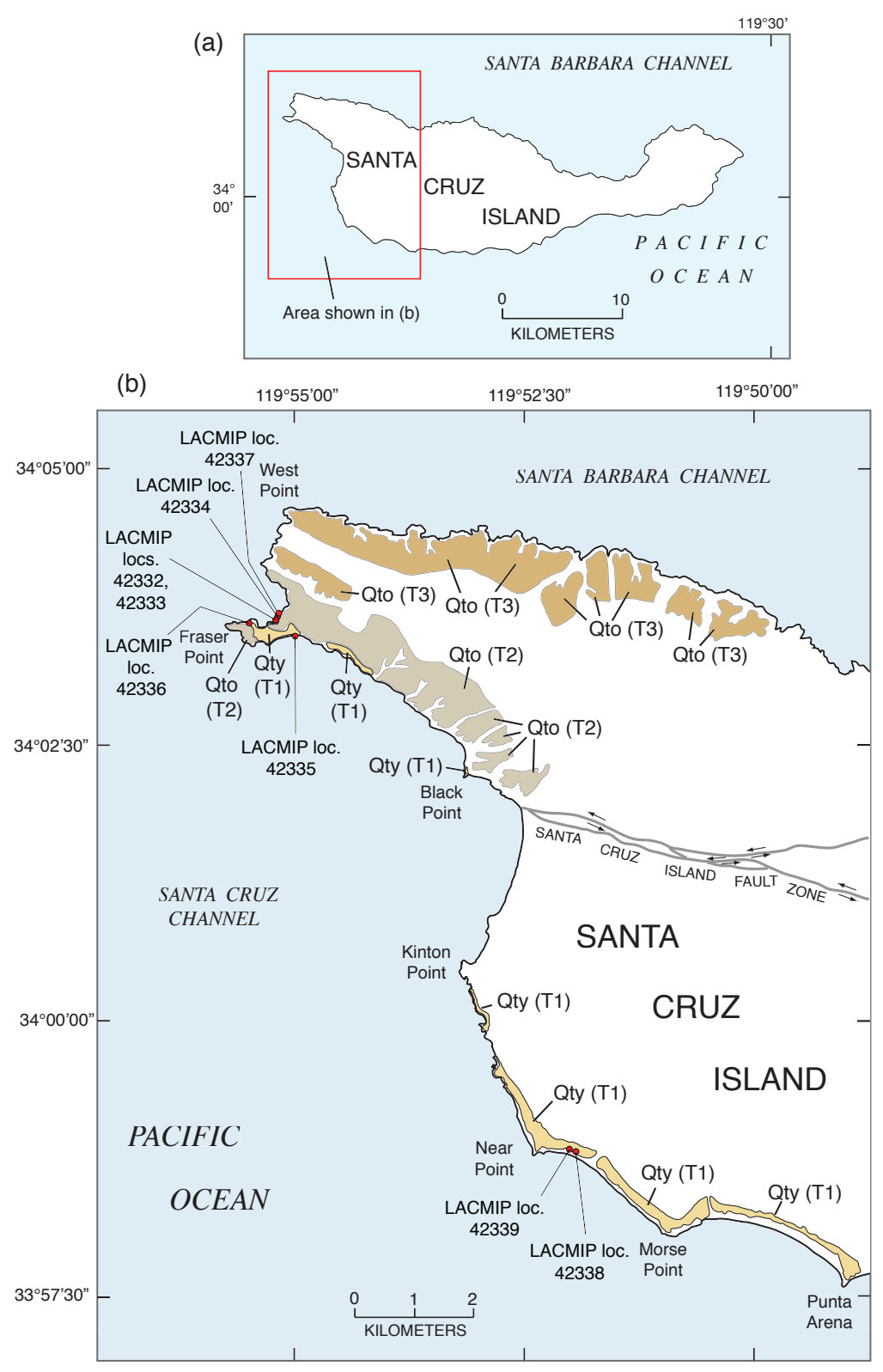

Fig. 7. (a) Map of Santa Cruz Island. The red box outlines the area shown in (b). (b) Northwestern part of Santa Cruz Island, California, showing the distribution of fossil localities (this study), older marine terraces, and undifferentiated (Qto; T2 and T3 in Fig. 8) and younger marine terraces (Qty; T1 in Fig. 8). Map in (b) is redrawn from Pinter et al. (1998, 2003).

deposits a short distance to the west, $\sim 4-5 \mathrm{~m}$ above the modern cobble beach at Frenchys Cove (Fig. 3). The higher terraces on West Anacapa Island were not studied in any detail and previous work (Scholl 1960, Johnson 1979) indicates that deposits of these higher terraces do not contain fossils.
Reconnaissance of Marine Terrace Deposits at Fraser Point, Santa Cruz Island

Marine terraces on Santa Cruz Island (Fig. 1) are most prominently displayed on the western part of the island between West Point and Fraser Point (Figs. 7, 8) and have been studied by Pinter et al. (1998, 2003). These investigators 


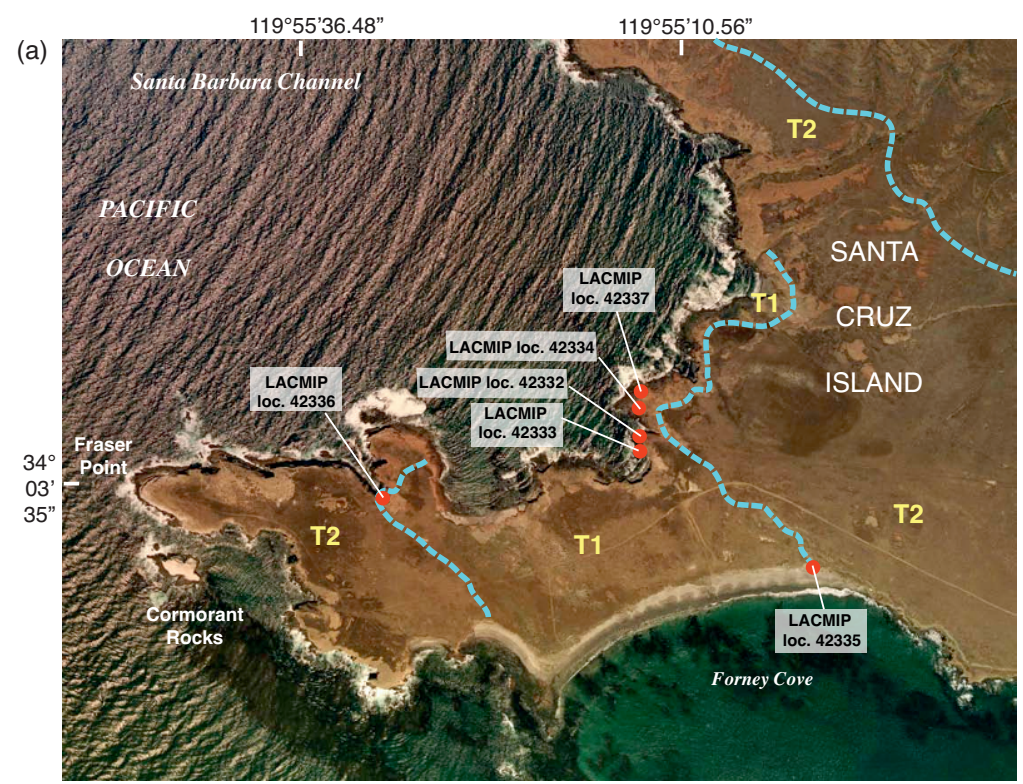

(b)

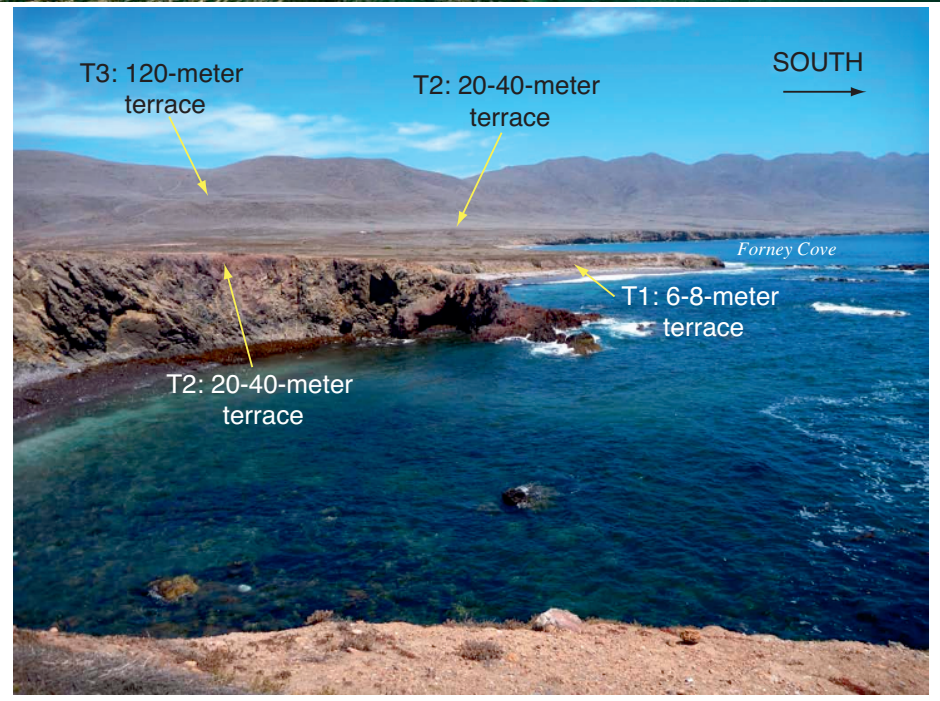

Fig. 8. (a) True-color aerial photograph of the Fraser Point area of Santa Cruz Island, California, showing fossil localities on T1 terrace shown in Fig. 7b. Aerial photograph courtesy of the U.S. National Park Service. Terrace boundaries (blue dashed lines) were mapped by the authors. (b) Ground photograph from the Fraser Point area of Santa Cruz Island showing T1, T2, and T3 terraces. Photograph by D.R. Muhs.

recognized three terraces: $\mathrm{T} 1, \mathrm{~T} 2$, and $\mathrm{T} 3$ (from youngest to oldest). The $\mathrm{T} 1$ terrace is found near Fraser Point but was also mapped by Pinter et al. (1998) between Kinton Point and Punta Arena, farther south (Fig. 7). Uraniumseries analyses of fossil corals from a locality close to Near Point gave ages of $\sim 120 \mathrm{ka}$, correlating this terrace with the peak of the LIG, or MIS 5.5 (Pinter et al. 1998). Although the same terrace is mapped near Fraser Point
(Pinter et al. 2003), no age estimates or fossil data for this part of the island have been reported previously.

The lowest two terraces were mapped in a small area of the Fraser Point area and several new fossil localities were found on the T1 terrace (Figs. 7, 8). Marine terrace deposits in the Fraser Point area are exposed in sea cliff walls and along surge channel walls. The deposits range in thickness from $\sim 0.5$ to $\sim 1.0 \mathrm{~m}$, and 
consist of sands and gravels. The shoreline angle of the $\mathrm{T} 1$ terrace is exposed at three places in the Fraser Point area. At LACMIP locs. 42332 and 42333, the shoreline angle was measured at $7.2 \mathrm{~m}$ above present sea level. The outer edge of the T2 terrace above it is $9.8 \mathrm{~m}$ above present sea level. The shoreline angle of $\mathrm{T} 1$ at LACMIP loc. 42336, which is exposed in a large surge channel, was measured at $7.5 \mathrm{~m}$ above present sea level. Here the outer edge of the $\mathrm{T} 2$ terrace above $\mathrm{T} 1$ lies at an elevation of $17.2 \mathrm{~m}$ above sea level. At two localities, the shoreline angle is not exposed but can be constrained by the highest bench elevation of the $\mathrm{T} 1$ terrace and the lowest elevation of the paleo-sea cliff above it. At LACMIP loc. 42334 , the highest bench is $8.3 \mathrm{~m}$ above present sea level and the lowest cliff above it is at $8.8 \mathrm{~m}$. At LACMIP loc. 42335 , the T1 terrace is $\sim 20 \mathrm{~m}$ wide, but overlying alluvium has obscured any possible exposures of the shoreline angle. Nevertheless, the outer bench is $4.2 \mathrm{~m}$ above present sea level and the lowest cliff above it is $11.4 \mathrm{~m}$, in broad agreement with the measurements of $\sim 7.2$ to $\sim 8.5 \mathrm{~m}$ above present sea level at the other localities.

Chlorostoma fossils were collected from several of the fossil localities for amino acid geochronology. In addition to the localities described above, fossils were collected between Near Point and Morse Point on Santa Cruz Island (LACMIP locs. 42338 and 42339; Fig. $7 \mathrm{~b}$ ), very close to the coral-bearing locality of Pinter et al. (1998). In addition, the late D.L. Johnson of the University of Illinois found a fossil locality in the Fraser Point area in 1978 (not previously published, but now registered as LACMIP loc. 42337) and a collection from it was given to the authors. We confirmed Johnson's locality in the field and made new collections as well. Fossils within the sediments are typical rocky-shore assemblages containing the bivalves Mytilus, Epilucina, and Glans and the gastropods Haliotis, Chlorostoma, Fissurella, Callianax, Thylacodes, Littorina, Californiconus, and Acmaea.

Aminostratigraphy of Low Terrace

Deposits on Santa Barbara Island, Anacapa

Island, and Western Santa Cruz Island

As pointed out by Wehmiller (1982, 1992 , 2013a, 2013b) and Miller et al. (2013), one of the most effective tests of the suitability of a given taxon for amino acid geochronology is to determine whether $\mathrm{D} / \mathrm{L}$ values of amino acids (or D-alloisoleucine/L-isoleucine values) in fossils are higher in older deposits, where a relative-age sequence of deposits can be found. Marine terraces of successively higher elevations form a morphostratigraphic framework for such a test. Two of the genera used in the present study, Chlorostoma and Epilucina, have been studied previously for amino acid geochronology (Wehmiller et al. 1977, Muhs 1985, Muhs et al. 1992). Presented here are mean values and standard deviations of $\mathrm{D}$ alloisoleucine/L-isoleucine in both genera shown as a function of relative terrace age on topographic profiles from San Nicolas Island, California, using data from Muhs (1985), Muhs et al. (1992), and new Chlorostoma data from the present study for the fourth terrace on this island (Fig. 9a). Both genera show increases in mean values with higher (older) terraces, confirming their utility for amino acid geochronology. Further, both genera show the ability to discriminate dated, late Pleistocene $(120 \mathrm{ka}$ to $80 \mathrm{ka})$ terrace deposits from older, middle-to-early Pleistocene terrace deposits.

Although a particular genus may be established as having the potential for geochronology, assessing the integrity of $\mathrm{D} / \mathrm{L}$ values in amino acids (or values of D-alloisoleucine/ L-isoleucine) in individual shells is not always simple because many of the diagenetic processes in host sediments that could affect amino acids are not well understood. Some of the potential problems and methods for assessing them have been identified by Kosnik and Kaufman (2008) and Kosnik et al. (2008) and are utilized here. Because the amino acid serine is relatively unstable and tends to be depleted over geologic timescales, the presence of high amounts of serine in a fossil shell indicates contamination by modern amino acids. Samples analyzed here were screened for this problem and none showed excessive serine concentrations. Another method of assessing fossil shell integrity and identifying outlier shells is accomplished with a simple procedure that identifies possible diagenetic gain or loss of amino acids. Kosnik and Kaufman (2008) point out that each amino acid racemizes independently of all others and at different rates. In principle, then, if a shell has experienced a closed-system history with respect to amino acids, $\mathrm{D} / \mathrm{L}$ values of two amino acids should increase systematically 
(b) Vizcaino Point-Thousand Springs area:

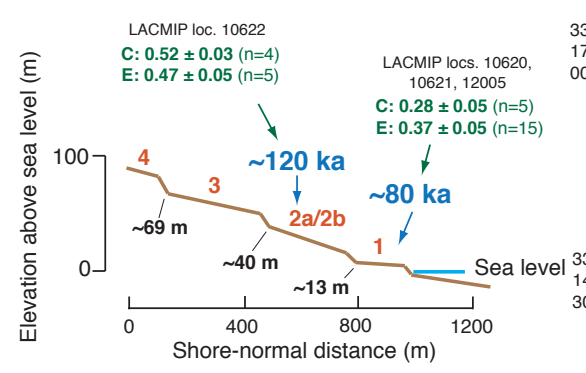

(c) Celery Creek canyon:

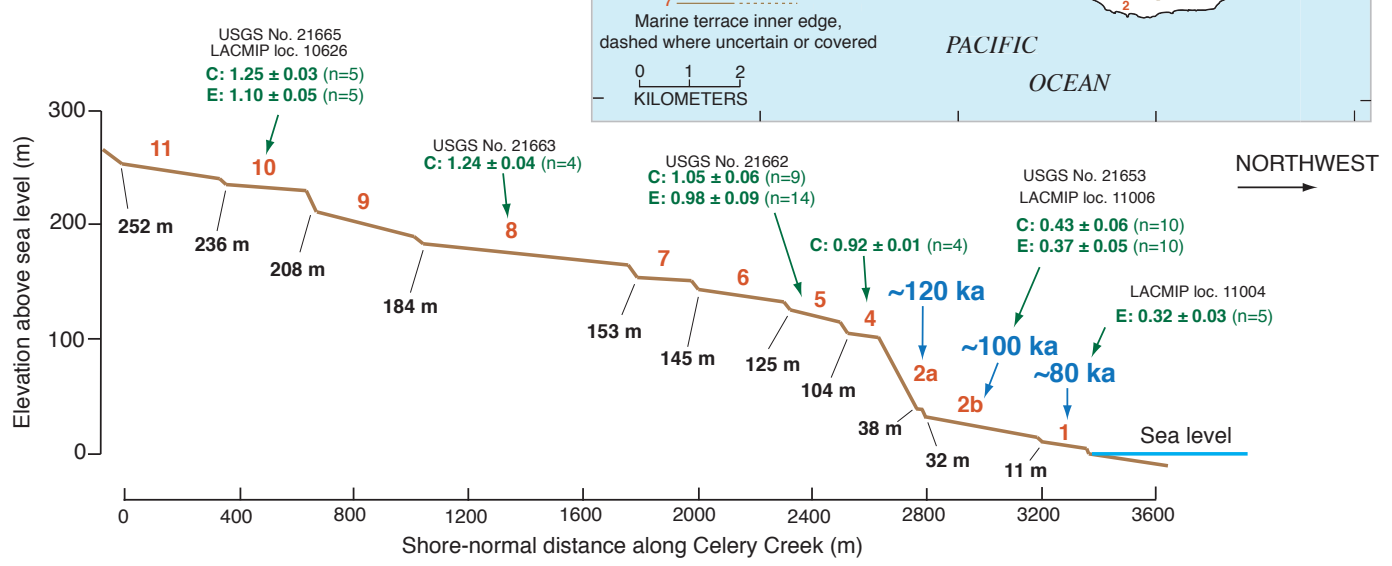

Fig. 9. Diagrams showing the ability of amino acids in mollusks to discriminate marine terraces of different ages: (a) Map of the inner edges of marine terraces on San Nicolas Island, California (see Fig. 1 for location; mapping from Vedder and Norris 1963 and Muhs et al. 2012). (b) Mean ratios and standard deviations of the amino acids D-alloisoleucine to L-isoleucine in Chlorostoma $(\mathrm{C})$ and Epilucina (E) fossils from terrace deposits in the Vizcaino Point area. Numbers in blue are U-series ages on corals (Muhs et al. 2006, 2012). (c) Same type of data as in (b) but for the Celery Creek Canyon area. Terrace elevations are from Vedder and Norris (1963) and Muhs et al. (2012, 2018). Amino acid data are from Muhs (1985) and Muhs et al. (1992). Note that in Muhs (1985), a locality (SN-10a) on the fifth terrace was erroneously listed as being on the fourth terrace; mean values presented here include all analyses from what were listed as the "fifth" and "fourth" terraces in Muhs (1985). Chlorostoma values given for the fourth terrace here are new analyses (AAL-13385-A, B, C, D) from a new collection (field \#SNI-GPS-325 at $33.258911^{\circ} \mathrm{N}, 119.489043^{\circ} \mathrm{W}$ ).

over time together. Shell integrity can therefore be assessed by a simple plot of $\mathrm{D} / \mathrm{L}$ values of two amino acids against each other from a suite of fossil shells. Kosnik and Kaufman (2008) demonstrate the utility of this method by identifying shells that deviate from regression lines in bivariate plots of $\mathrm{D} / \mathrm{L}$ aspartic acid versus D/L glutamic acid (see their Fig. 3). In the present study, both Chlorostoma and Epilucina were assessed in this fashion by plotting $\mathrm{D} / \mathrm{L}$ glutamic acid versus $\mathrm{D} / \mathrm{L}$ valine (Fig. 10). Amino acid data from Muhs et al. (2014c) were evaluated independently and then aggregated with new data from the present study. Results show that linear fits to the data have high correlation coefficients, and few or no data points appear as obvious or extreme outliers. This exercise implies that shells of both genera in the present study have likely experienced closed-system histories with respect to at least glutamic acid and valine.

In the studies of fossils from the marine terrace deposits of SBI, West Anacapa Island, and western Santa Cruz Island presented here, the aminostratigraphic framework presented by Muhs et al. (2014a, 2018) that extends along the coast of North America from northern Baja California to central California was utilized in a modified form. Uranium-series ages of corals from marine terrace localities studied by Muhs 
(a)

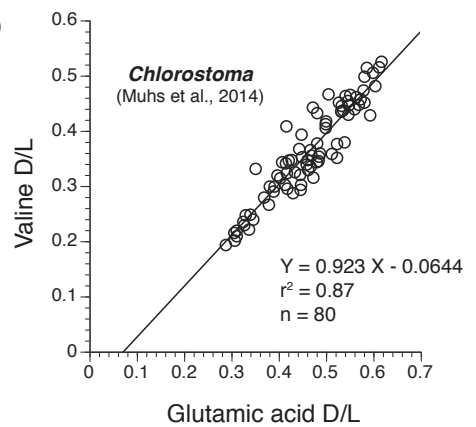

(b)

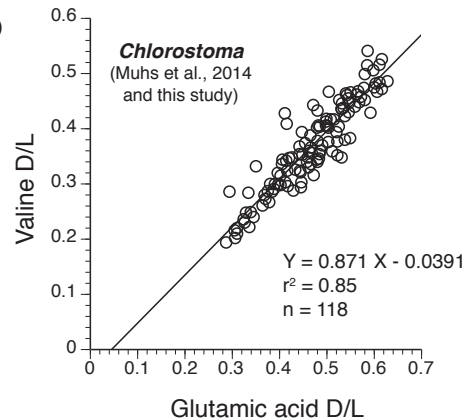

(c)

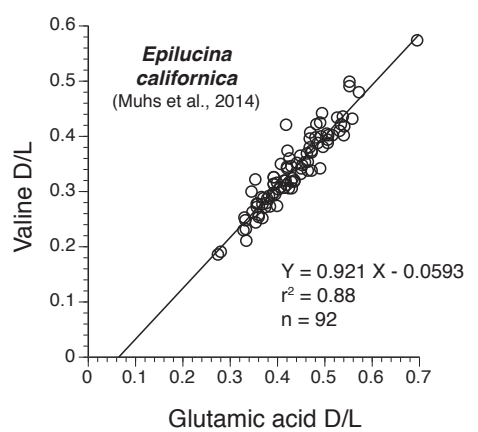

(d)

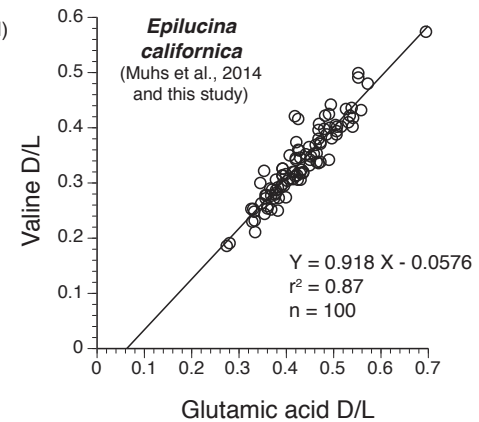

Fig. 10. Plots of $\mathrm{D} / \mathrm{L}$ values (peak height ratios) of glutamic acid versus $\mathrm{D} / \mathrm{L}$ values of valine in individual shells of Chlorostoma (a, b) and Epilucina californica (c, d) and regression lines fitted to these data. Data in (a) and (c) are from Muhs et al. (2014a). Data in (b) and (d) are from Muhs et al. (2014a) and data in Appendixes 1 and 4.

et al. (1994, 2012, 2014a, 2015) and Pinter et al. (1998) are used to define aminozones of different ages. Presented here are latitudinal plots of $\mathrm{D} / \mathrm{L}$ values for glutamic acid and valine for both Chlorostoma and Epilucina and D-alloisoleucine/L-isoleucine in Chlorostoma and Chione for these dated localities along with new data from SBI, West Anacapa Island, and Santa Cruz Island (Figs. 11-13).

Glutamic acid and valine $\mathrm{D} / \mathrm{L}$ values in Chlorostoma samples from SBI and West Anacapa Island show much more variability than values in shells from other southern California localities. Indeed, D/L values in Chlorostoma shells from these two islands appear to fall into two groups. For both glutamic acid and valine, two or more shells from each island have $\mathrm{D} / \mathrm{L}$ values that fall within or close to the 120-ka aminozone while the others fall into the $~ 80$-ka aminozone (Fig. 11). For Dalloisoleucine/L-isoleucine, we also observe two groupings of values for West Anacapa Island, but the values in Chlorostoma shells in the higher group on SBI fall within the 100-ka to 80-ka aminozone (Fig. 12a). The mean of five Epilucina shells analyzed from SBI falls within the 80-ka aminozone for both glutamic acid and valine but with a high amount of variability (Fig. 13). On West Anacapa Island, only three Epilucina shells were found. Mean values for both glutamic acid and valine in these three shells fall between the $~ 120$-ka and 80-ka aminozones. Because there are no obvious outliers in the $\mathrm{D} / \mathrm{L}$ glutamic acid versus $\mathrm{D} / \mathrm{L}$ valine plots (Fig. 10), this variability is interpreted to reflect real differences in age.

On Santa Cruz Island, from the locality near Pinter et al.'s (1998) coral-bearing site between Near Point and Morse Point (LACMIP loc. 42339; Fig. 7b), Chlorostoma D/L values for glutamic acid and valine and $\mathrm{D}$ alloisoleucine to L-isoleucine all plot within the $\sim 120$-ka aminozone (Figs. 11, 12a), consistent with the U-series ages on coral of $\sim 120 \mathrm{ka}$ from these deposits. At Fraser Point farther west, we obtained D/L values for Chlorostoma from two localities (LACMIP loc. 42335 and LACMIP loc. 42337), one exposed to the south and one exposed to the north (Figs. 7, 8). For all three ratios in Chlorostoma $(\mathrm{D} / \mathrm{L}$ glutamic acid, D/L valine, and D-alloisoleucine/ L-isoleucine), values plot squarely within the 
-120-ka aminozone, correlating this terrace with the dated locality (LACMIP loc. 42339) on southern Santa Cruz Island and other southern California localities (Figs. 11, 12a).

A third genus, Chione, was utilized for amino acid geochronology. Fossils of this taxon were not found on SBI or Santa Cruz Island, but a number of fossil specimens of this genus were found on West Anacapa Island. Because all species of this genus are southward ranging, many of the localities for independent age control lie to the south of West Anacapa Island. The southernmost locality is Mulegé, Baja California Sur (Fig. 1a). Ortlieb (1978, 1987) described the geology of this area, and Ashby et al. (1987) reported U-series ages of $\sim 120 \mathrm{ka}$ on coral from this locality. Ortlieb (1987) reported amino acid data for Chione from Mulegé. His analyses were conducted in the Amino Acid Geochronology Laboratory of the University of Colorado, so his data are directly comparable to those presented here. Uranium-series analyses on coral have been conducted at some other localities; we report new amino acid analyses of Chione from these localities, taken either from collections made by the authors or from collections archived in the Department of Invertebrate Paleontology at the Natural History Museum of Los Angeles County (LACMIP). These other locations include Bahía de Magdalena, Baja California Sur, where Omura et al. (1979) report U-series analyses on coral, and Newport Bay, Orange County, California, where Grant et al. (1999) also report U-series analyses on coral, yielding ages of $\sim 120 \mathrm{ka}$. There is one Chione-bearing locality of LIG age that lies well to the north of West Anacapa Island at Toms Point in Tomales Bay, Marin County, California, $\sim 67 \mathrm{~km}$ northwest of San Francisco (Fig. 1a). Marine deposits here (called the Millerton Formation) were described by Johnson (1962) and were dated using thermoluminescence techniques to $\sim 130$ ka by Grove et al. (1995). Thus, along a south-to-north temperature gradient, a suite of independently dated Chione-bearing localities that bracket West Anacapa Island were obtained.

In addition to estimating the age of the low terrace on West Anacapa Island, ratios of D-alloisoleucine to L-isoleucine in Chione are also the basis of our comparison of a protected, quiet-water fossil fauna on the main- land California coast with fauna of the rocky intertidal environments of ANA and SBI. In the San Pedro area of Los Angeles County, California, Woodring et al. (1946) reported that one of the most widespread late Quaternary marine deposits is the Palos Verdes Sand (Fig. 14). No corals suitable for U-series dating have been reported in this deposit nor were any found in the present study, but $\mathrm{D} / \mathrm{L}$ values and oxygen isotope values in Leukoma staminea (formerly Protothaca staminea) led Muhs et al. (1992) to conclude that the Palos Verdes Sand in at least northern San Pedro could date to the $\sim 120$-ka high-sea stand (MIS 5.5). Because specimens of Chione spp. from the Palos Verdes Sand at the same locality in northern San Pedro (LACMIP loc. 12576; see Fig. 14) are abundant, we analyzed shells of this taxon from this site. Finally, another locality where Chione fossils are abundant but where no independent ages exist is within marine deposits a few meters above modern sea level near Puerto Peñasco, Sonora, in the upper Golfo de California (Fig. 1), described by Davis et al. (1990). Dr. Nicholas Lancaster of the Desert Research Institute, Reno, Nevada, kindly collected some Chione specimens from this locality for us.

Results show that, similar to Chlorostoma and Epilucina, fossil Chione shells show decreasing values of $\mathrm{D}$-alloisoleucine to $\mathrm{L}$ isoleucine from south to north in deposits known by independent dating to be of similar age (Fig. 12b). The results presented here for Chione are similar to those reported by Wehmiller et al. (1977), Wehmiller and Emerson (1980), Kennedy et al. (1982), and Wehmiller (1982) using Protothaca and Chione amino acid data for Toms Point, San Pedro, Newport Bay, and Bahía de Magdalena. Dalloisoleucine/L-isoleucine values in Chione shells from West Anacapa Island fall within the aminozone defined by these dated localities, correlating the deposits on that island with the $\sim 120$-ka high-sea stand. Ratios of Dalloisoleucine to L-isoleucine in Chione from the Palos Verdes Sand at San Pedro also fall within this aminozone, supporting the earlier conclusion of Muhs et al. (1992) that this deposit, at least in northern San Pedro, correlates to the $\sim 120$-ka (MIS 5.5) high-sea stand. Similarly, Chione shells from the low-elevation marine deposits at Puerto Peñasco, Sonora, 
(a) NORTHWEST
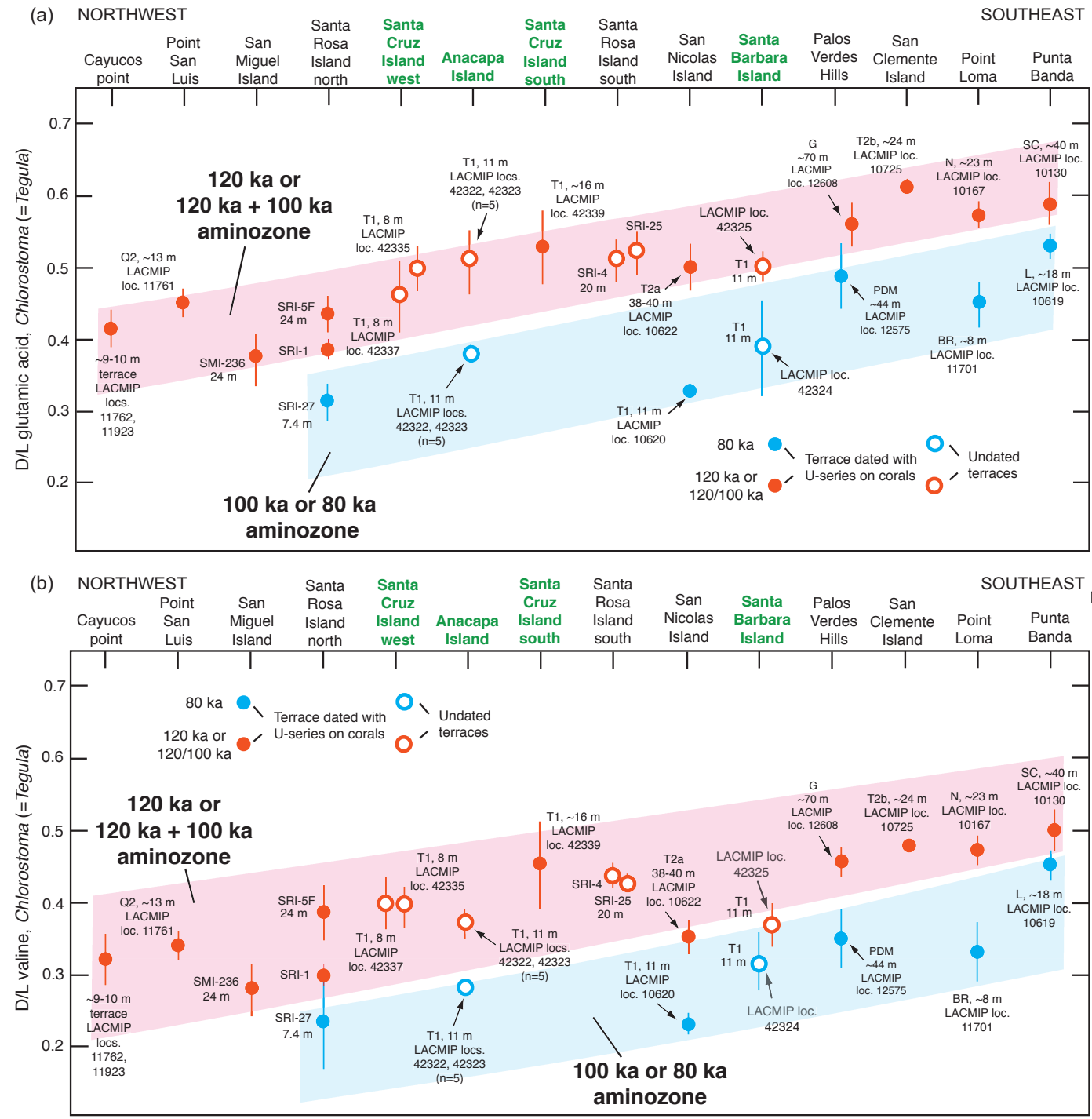

Fig. 11. (a) Plot of mean D/L values in glutamic acid (vertical axis) in Chlorostoma fossils from dated (filled circles) and undated (open circles) marine terraces on the California and Baja California coast shown as a function of latitude (horizontal axis) as a proxy for long-term temperature history (cooler in the northwest, warmer in the southeast). Error bars are $\pm 1 \mathrm{SD}$ based on D/L values in 3 to 6 individual shells from the same deposit. The red and blue bands ("aminozones") indicate a correlation between fossil localities of the same age, anchored by U-series dating of corals. Terrace name abbreviations: SMI $=$ San Miguel Island, SRI = Santa Rosa Island, SCRZI = Santa Cruz Island, N $=$ Nestor, BR $=$ Bird Rock, PDM = Paseo del Mar, G = Gaffey, SC = Sea Cave, and L = Lighthouse. See Muhs et al. (1994, 2002a, 2006, 2014a, 2015) for terrace stratigraphic names and U-series ages. Data from Santa Cruz Island-West, Anacapa Island, Santa Cruz Island-South, and Santa Barbara Island (shown in bold green text along the top horizontal axis) are from the present study; other data are from Muhs et al. (2014a). (b) Same type of data as in (a) but for mean D/L values in valine.

Fig. 12. See page 559. (a) Plot of mean D-alloisoleucine to L-isoleucine (vertical axis) in Chlorostoma fossils from dated (filled circles) and undated (open circles) marine terraces on the California and Baja California coast shown as a function of latitude (horizontal axis) as a proxy for long-term temperature history (cooler in the northwest, warmer in the southeast). Error bars are $\pm 1 \mathrm{SD}$ based on $\mathrm{D} / \mathrm{L}$ values in 3 to 6 individual shells from the same deposit. The red and blue bands ("aminozones") indicate a correlation between fossil localities of the same age, anchored by U-series dating of corals. Terrace name abbreviations: SCRZI = Santa Cruz Island, $\mathrm{N}=$ Nestor, BR = Bird Rock, PDM = Paseo del Mar, G = Gaffey, SC $=$ Sea Cave, and L = Lighthouse. See Muhs et al. (1994, 2002a, 2006, 2014a, 2015) for terrace stratigraphic names and U-series ages. See Fig. 14 for the location of fossil sites on the PDM and G terraces in the San Pedro area. Data from Point San Luis, Santa Cruz Island-West, Anacapa Island, Santa Cruz Island-South, Santa Barbara Island, and Point Loma are 

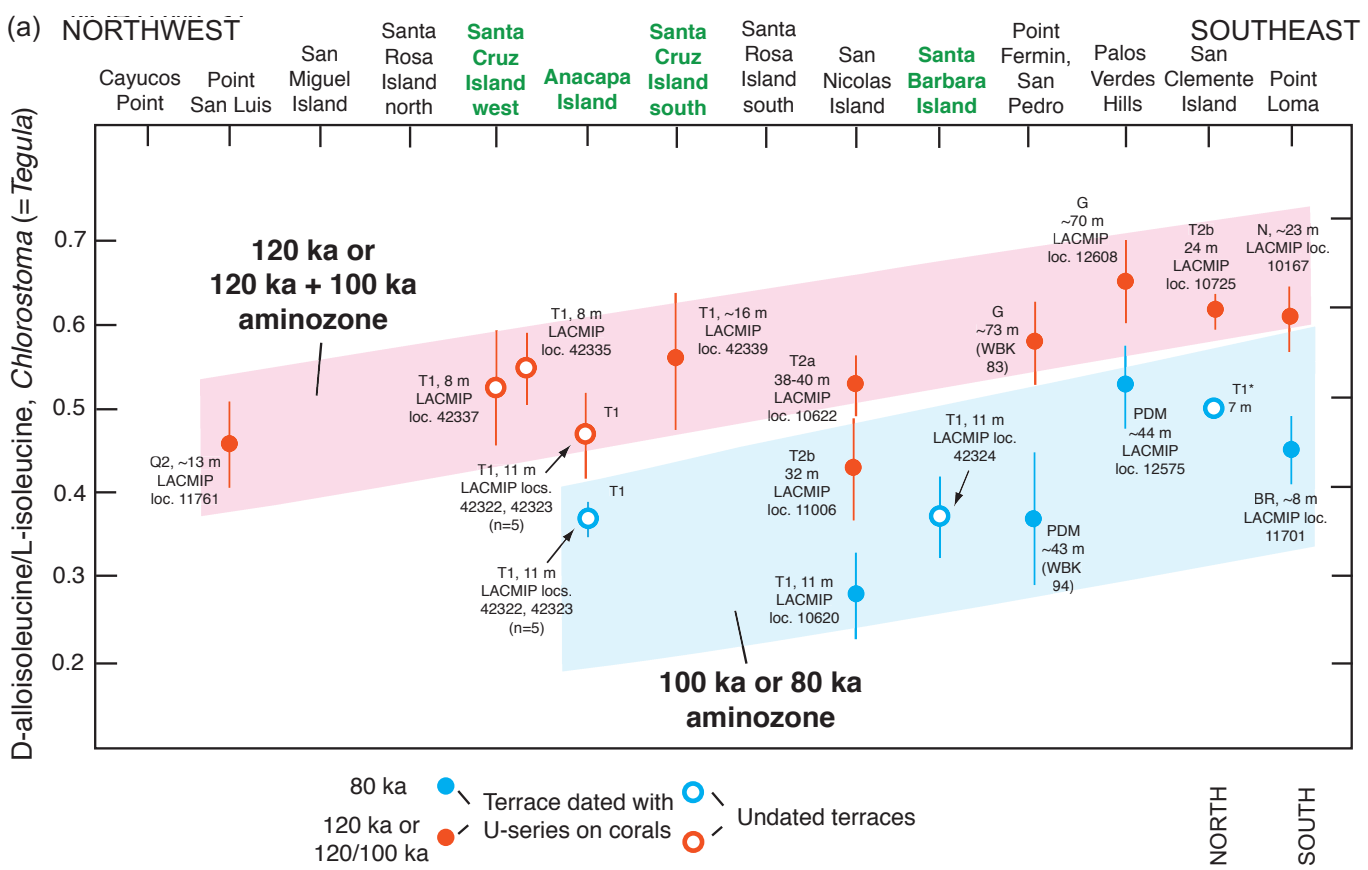

(b)

Pacific coast

SOUTH Golfo de California

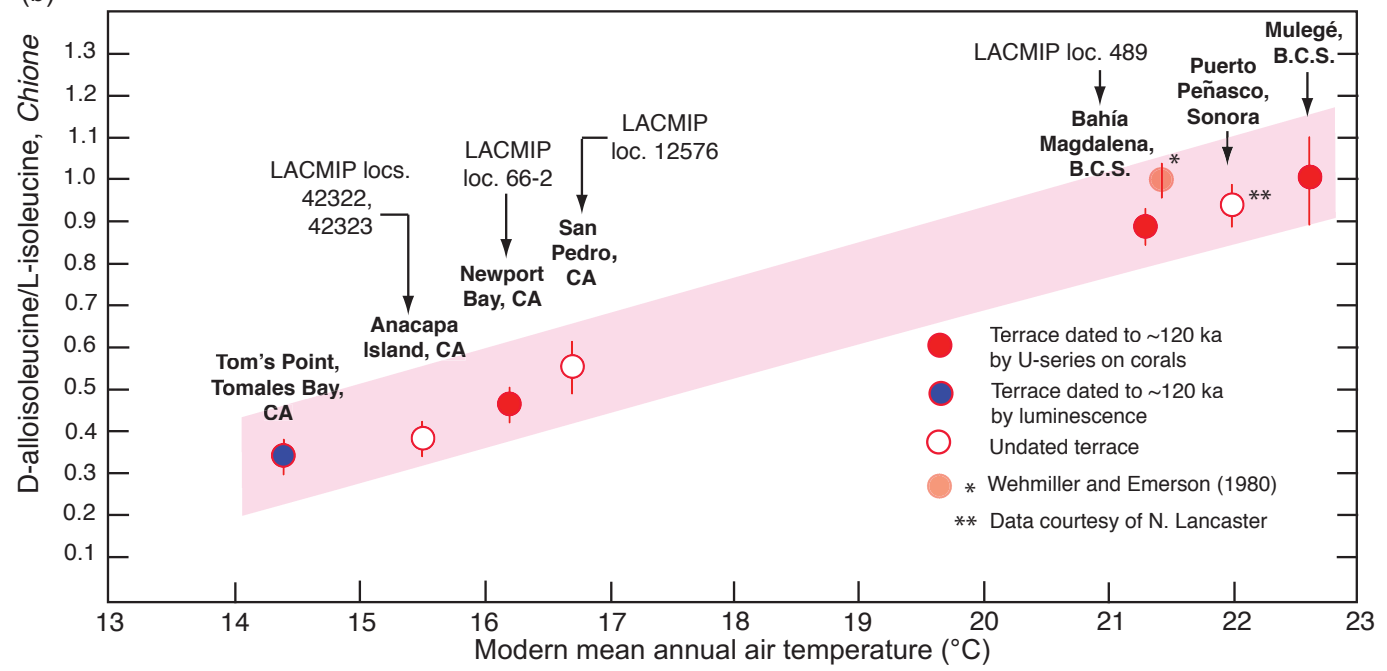

from the present study and were derived by reverse-phase liquid chromatography (Kaufman and Manley 1998); other data, with one exception, are from Muhs et al. (1992) and were derived by conventional liquid chromatography (Miller 1985). The value shown for the low $(\sim 7 \mathrm{~m})$ first terrace on San Clemente Island is from Muhs (1983); although derived via liquid chromatography, the method differs somewhat from the conventional liquid chromatography in use at the University of Colorado laboratory since 1985 (see discussion in Miller 1985). (b) Plot of mean D-alloisoleucine to L-isoleucine (vertical axis) in Chione fossils from dated (filled circles) and undated (open circles) marine terraces on the California and Baja California coast shown as a function of approximate present mean annual air temperature (horizontal axis). Error bars are \pm 1 SD based on $\mathrm{D} / \mathrm{L}$ values in 4 to 6 individual shells from the same deposit. U-series ages of $\sim 120 \mathrm{ka}$ on coexisting corals are from the following sources: Mulegé, Baja California Sur (B.C.S.), from Ashby et al. (1987); Bahía Magdalena, B.C.S., from Omura et al. (1979); and Newport Bay, California, from Grant et al. (1999). Luminescence age of $\sim 120-130$ ka from Tomales Bay is from Grove et al. (1995). Chione shells from Tomales Bay, Anacapa Island, and San Pedro were collected by the authors; shells from Newport Bay and Magdalena Bay are from collections in the Invertebrate Paleontology Section at the Natural History Museum of Los Angeles County. The collection from Puerto Peñasco was made by Nicholas Lancaster and analyzed by the authors. Data from Mulegé are from Ortlieb (1987), but amino acid analyses in Chione from this author were derived in the laboratory at the University of Colorado and thus are directly comparable to the other data. For the locations of Mulegé, Bahía Magdalena, Puerto Peñasco, San Pedro, Newport Bay, and Tomales Bay, see Figs. 1 and 16. 

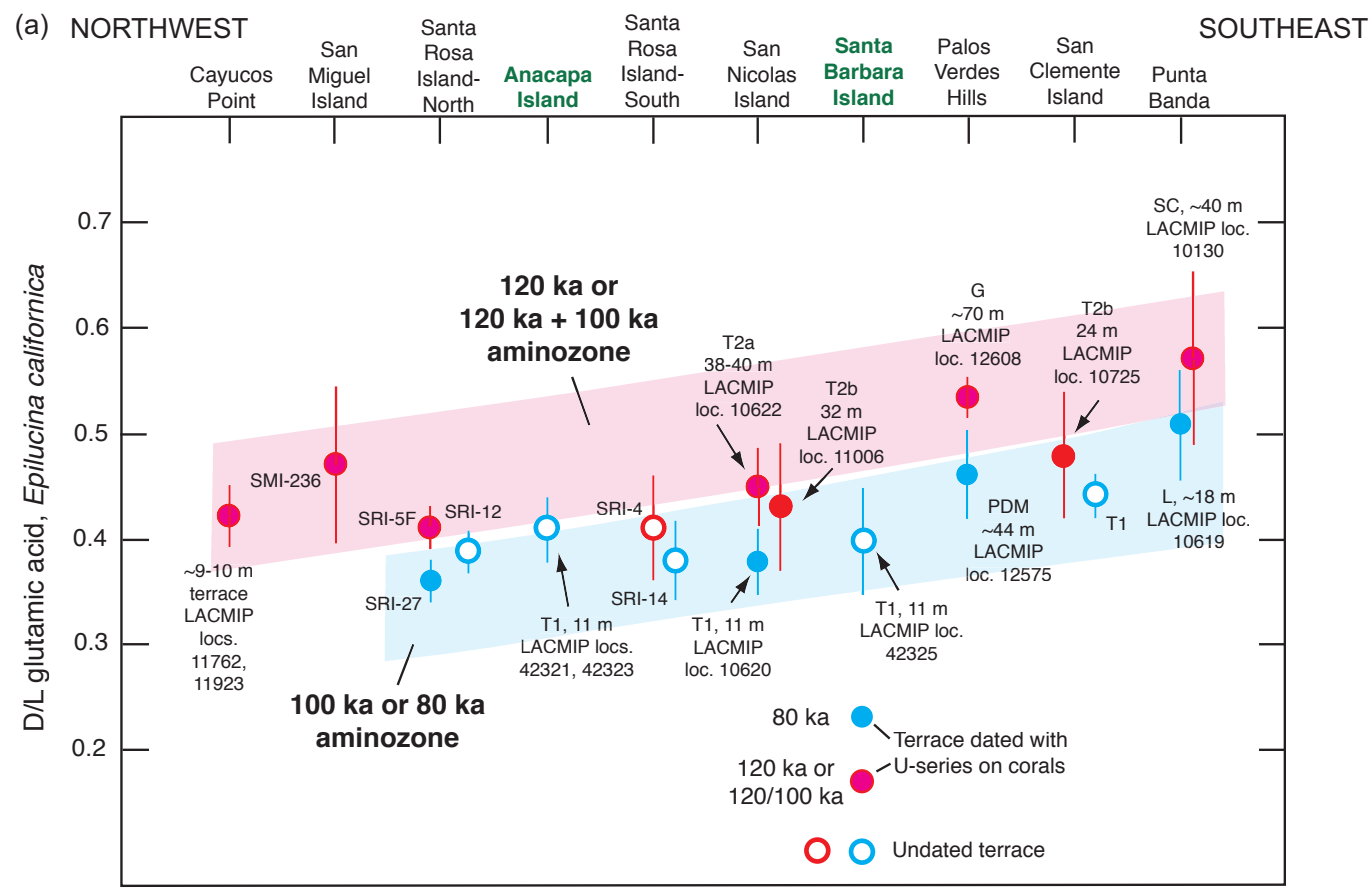

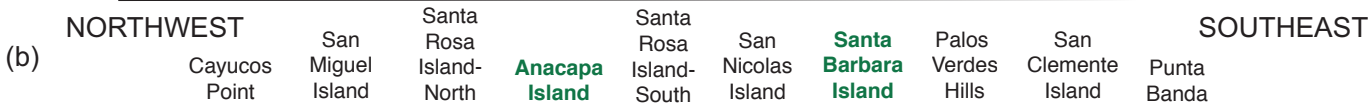

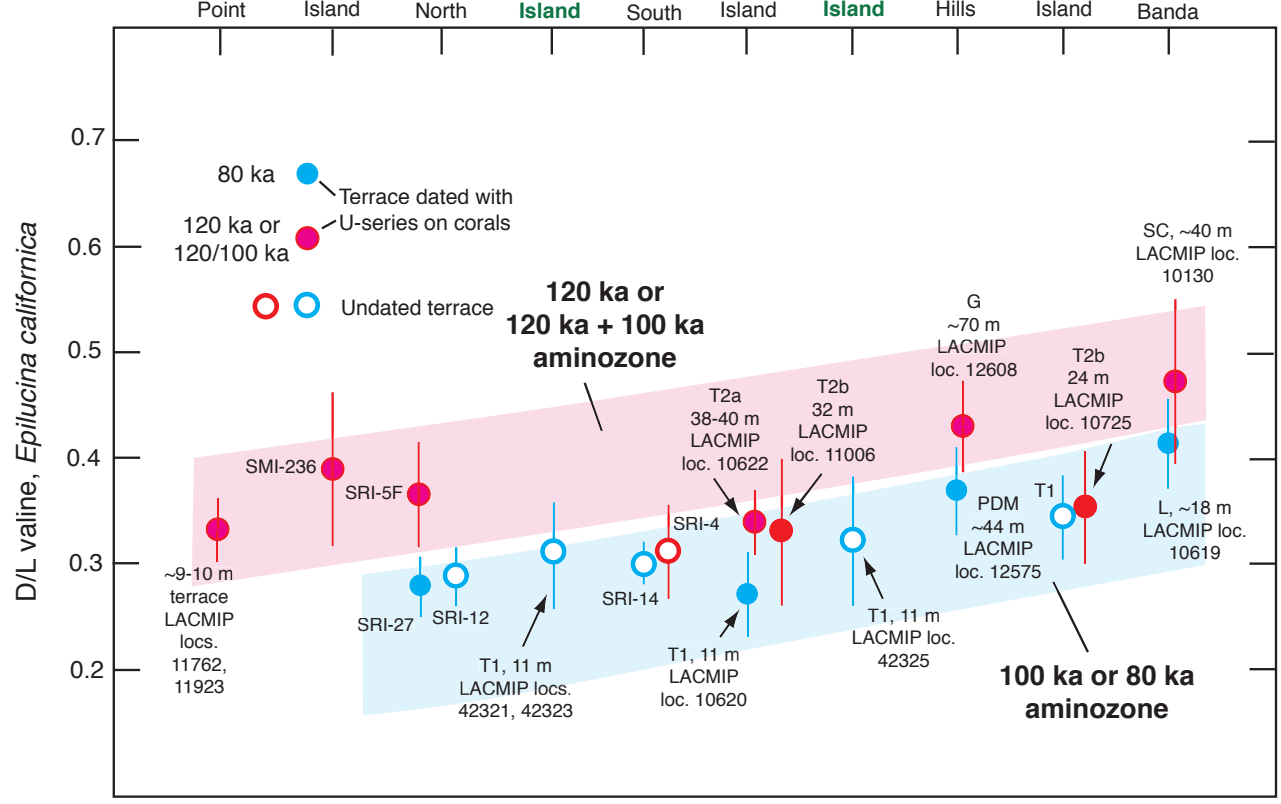

Fig. 13. (a) Plot of mean D/L values in glutamic acid (vertical axis) in Epilucina californica fossils from dated (filled circles) and undated (open circles) marine terraces on the California and Baja California coast shown as a function of latitude (horizontal axis) as a proxy for long-term temperature history (cooler in the northwest, warmer in the southeast). Error bars are $\pm 1 \mathrm{SD}$ based on $\mathrm{D} / \mathrm{L}$ values in 1 to 5 individual shells from the same deposit. The red and blue bands indicate a correlation between fossil localities of the same age based on U-series dating of corals. Terrace name abbreviations: SMI = San Miguel Island, SRI $=$ Santa Rosa Island, PDM $=$ Paseo del Mar, G = Gaffey, SC $=$ Sea Cave, and L $=$ Lighthouse. See Muhs et al. (1994, 2002a, 2006, 2014a, 2015) for terrace stratigraphic names and U-series ages. Data from Anacapa Island and Santa Barbara Island (shown in bold green text along the top horizontal axis) are from the present study; other data are from Muhs et al. (2014a). (b) Same type of data as in (a) but for mean D/L values in valine. 


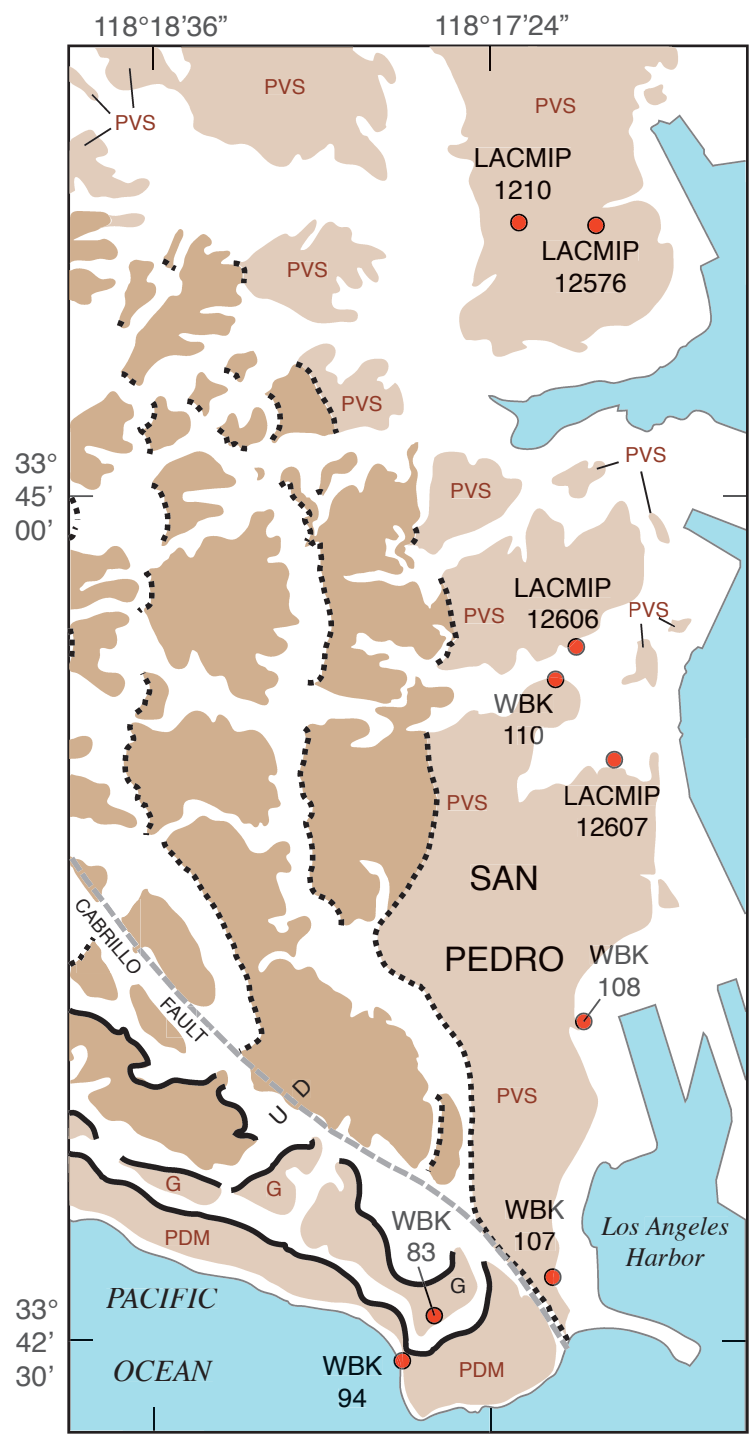

\section{EXPLANATION \\ PVS \\ Palos Verdes \\ Sand or \\ terrace deposits \\ (G, PDM) correlative \\ with the \\ Palos Verdes \\ Sand

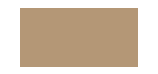

Marine deposits

older than the

Palos Verdes

Sand

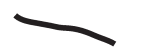

Terrace inner

edge, well-

expressed

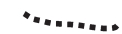

Terrace inner edge,

uncertain or approximate
- LACMIP 12576
- WBK
94

Fossil localities

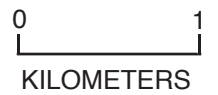

Fig. 14. Map of the Palos Verdes Sand (PVS) in the San Pedro area with labeled marine terrace deposits nearby that are thought to be of equivalent age $(\mathrm{G}=$ Gaffey terrace, $\sim 120 \mathrm{ka}$, and PDM $=$ Paseo del Mar terrace, $\sim 80 \mathrm{ka}$, from Muhs et al. 2006), marine terrace deposits older than the Palos Verdes Sand, and fossil localities discussed in the text. Warm-water species found at LACMIP locality 12576 are shown in Fig. 15b. Amino acid data in Fig. 12a for the Paseo del Mar (PDM) terrace are from locality WBK 94. Amino acid data in Fig. 12a for the Gaffey $(\mathrm{G})$ terrace are from locality WBK 83. WBK numbers are fossil localities of Woodring et al. (1946); other numbers are all LACMIP (Natural History Museum of Los Angeles County, Department of Invertebrate Paleontology) localities. Terrace distributions and the location of the Cabrillo Fault are redrawn from Woodring et al. (1946) and Muhs et al. (1992, 2006).

have values that fall between those of Bahía de Magdalena and Mulegé, correlating these deposits with the $\sim 120$-ka high-sea stand as well. The Chione amino acid results from both San Pedro and Puerto Peñasco are important for paleozoogeographic comparisons discussed later.

\section{Paleontology of Marine Terrace Deposits}

On both SBI and ANA, an observation made is absence of an extinct gastropod, Calicantharus fortis, on the 11-m-high terraces of both islands, though this species is present on higher terraces. On SBI, C. fortis was found 
on what is mapped as the second, third, and fourth terraces. On Middle Anacapa Island, C. fortis is present within the deposits of the 70-m-high terrace, as reported by Valentine and Lipps (1963) and confirmed in the present study. This taxon has also been found in deposits of high-elevation marine terraces on San Miguel Island, Santa Rosa Island, San Nicolas Island, and San Clemente Island. Thus far, C. fortis has not been reported in any marine terrace deposit dated to as young as $\sim 120 \mathrm{ka}$, with two exceptions. One of these is the Palos Verdes Sand (thought to be of LIG age) in San Pedro, but Woodring et al. (1946) interpreted this as an isolated case of an older shell reworked, perhaps by hermit crabs, into younger deposits. On San Nicolas Island, a single specimen of $C$. fortis was reported from a terrace dated to $\sim 120 \mathrm{ka}$ (Muhs et al. 2012), but also is interpreted to be derived from higher terrace deposits where the species is commonly found (Vedder and Norris 1963). Thus, it is inferred that C. fortis is likely older than the LIG period (MIS 5.5) and is one of the few Pleistocene species that serves as an effective biostratigraphic marker, making it possible to separate pre-LIG deposits from older Pleistocene deposits. The presence of C. fortis on the higher terraces and its absence on the 11-m-high terraces of SBI and ANA reinforce the aminostratigraphic interpretation that these low terraces date to $\sim 120 \mathrm{ka}$ or younger high-sea stands. The low (6-8 m) marine terrace deposits at Fraser Point on Santa Cruz Island also lack C. fortis, in agreement with the aminostratigraphic correlation to the LIG period.

Fossils in deposits of the 11-m-high first marine terrace of eastern SBI are dominated by mollusks that are typical of high-waveenergy, rocky-shore assemblages (McLean 1978, Coan et al. 2000). This observation derives from both new collections made in the present study (Table 1) and a reexamination of collections made by Lipps et al. (1968) and E. Wilson (LACMIP loc. 5068; Fig. 2) that are archived at LACMIP. At locality LACMIP loc. 42324 (at or near Lipps et al.'s [1968] LACMIP loc. 329), common taxa in the deposit are the bivalves Cumingia, Epilucina, and Glans and the gastropods Acmaea, Chlorostoma, Crepidula, Fissurella, Haliotis, Littorina, and Thylacodes, as well as sea urchin (Strongylocentrotus sp.?) plates and spines, barnacles
(Balanus sp.?), and the solitary coral Balanophyllia elegans. A significant number of the Epilucina valves are paired. These taxa are all indicative of an exposed, high-energy, rocky intertidal environment. Many of these taxa are also found in the other collections archived at LACMIP and newly examined in the present study (Table 1). These include species from LACMIP localities 326, 327, 329, and 42325 [= LACMIP loc. 5068], all of which are on the same 11-m-high terrace (Fig. 2). Most of the species found at all five localities on this terrace have modern geographic ranges that extend well to the north and south of SBI. There are exceptions to this, however, and those are discussed in more detail later.

On West Anacapa Island there is a much less diverse fossil fauna in deposits of the $11-m$ terrace than on the 11-m terrace of SBI (Table 2). The overall character of the fauna is also a rocky intertidal assemblage with the bivalves Epilucina californica and Mytilus californianus and species of the gastropods Acmaea, Chlorostoma, Crepidula, Haliotis, Littorina, Lottia, and Mitra. Nevertheless, there is also a significant element in the fauna that is more typical of a quiet-water, sandy or muddy "bay" environment (McLean 1978, Coan et al. 2000) with bivalve species such as Chione californiensis, Crassadoma gigantea, Leopecten diegensis, Ostrea lurida, Saxidomus sp., and Tresus nuttallii. Again, the majority of taxa have modern ranges that extend well to the north and south of ANA, with some important exceptions discussed below.

\section{DISCUSSION}

Correlation of Marine Terraces on Santa Barbara Island, Anacapa Island, and Western Santa Cruz Island with Last Interglacial Sea Level History

Although U-series ages on corals from both SBI and ANA are lacking, aminostratigraphic methods make possible the correlation of the terraces on these two islands with U-seriesdated deposits from other localities. Based on $\mathrm{D} / \mathrm{L}$ values in Chlorostoma, Epilucina, and Chione, the terraces on SBI and ANA correlate broadly with the LIG complex MIS 5. This correlation is supported by the fact that the 11-m-high terrace deposits on both islands do not contain the extinct gastropod Calicantharus fortis, which is found only in deposits of 
TABLE 1. Marine terrace fossils from Santa Barbara Island, California.

LACMIP locality number

Taxon

326

327

329

42325,5068

Mollusca

Gastropoda

Acanthinucella punctulata (Sowerby I, 1835)

Acanthinucella spirata (Blainville, 1832)

Acmaea mitra Rathke, 1833

Acteocina sp.

Actonia oldroydae (Bartsch, 1911)

Aesopus chrysalloides (Carpenter, 1864)

Alia carinata (Hinds, 1844)

Alvinia cosmia (Bartsch, 1911)

Alvinia purpurea (Dall, 1871)

Amphissa versicolor Dall, 1871

Amphithalamus tenuis Bartsch, 1911

Antisabia panamensis (C.B. Adams, 1852)

Assiminea californica (Tryon, 1865)

Astyris tuberosa (Carpenter, 1864)

Barbarofusus sp.

Barleeia haliotiphila Carpenter, 1864

Barleeia sp.

Caecum californicum Dall, 1885

Californiconus californicus (Reeve, 1844)

Callianax biplicata (Sowerby I, 1825)

?Calliostoma sp.

Cerithiopsis antefilosa Bartsch, 1911

Chlorostoma funebralis (A. Adams, 1855)

Chlorostoma gallina (Forbes, 1852)

Crepidula adunca (Sowerby I, 1825)

Crepidula perforans (Valenciennes, 1846)

Crepidula sp.

Crepipatella lingulata (Gould, 1846)

Crockerella conradiana (Gabb, 1866)

Diodora arnoldi McLean, 1966

Discurra insessa (Hinds, 1842)

Epitoniid indet.

Eulithidium sp.

Fartulum orcutti (Dall, 1885)

Fissurella volcano Reeve, 1849

Granulina margaritula (Carpenter, 1857)

Haliotis cracherodii Leach, 1814

Haliotis rufescens (Swainson, 1822)

Haliotis sp.

Harfordia harfordii (Stearns, 1871)

Harfordia sp.

Hima mendica (Gould, 1849)

Hipponix tumens Carpenter, 1864

Homalopoma luridum (Dall, 1885)

Homalopoma radiatum (Dall, 1918)

Lacuna unifasciata Carpenter, 1857

Lirobittium attenuatum Carpenter, 1864

Lirobittium quadrifilatum (Carpenter, 1864)

Lirobittium sp.

Lirularia sp.

Littorina keenae Rosewater, 1978

Littorina scutulata Gould, 1849

Lottia limatula (Carpenter, 1864)

Lottia pelta (Rathke, 1833)

Lottia scabra (Gould, 1846)

Lottia sp.

Megastraea undosa (Wood, 1828)

Melanella thersites (Carpenter, 1864)

Mexacanthina lugubris (Sowerby I, 1822)

Mitra idae Melvill, 1893

$x+1$
$x$
$x$
$x$
$x$
$x$
$x$
$x$
$x$
$x$

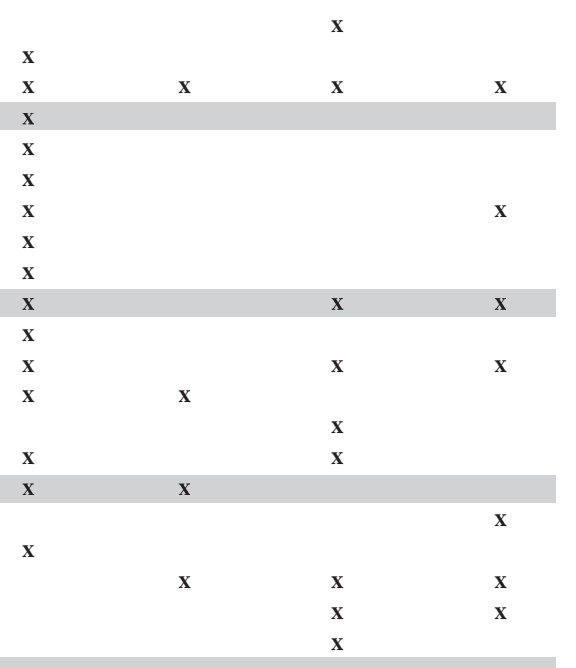

$\begin{array}{lllll}\mathbf{x} & & & \\ \mathbf{x} & \mathbf{x} & \mathbf{x} & \mathbf{x} \\ \mathbf{x} & \mathbf{x} & \mathbf{x} & \mathbf{x} \\ \mathbf{x} & & \mathbf{x} \\ \mathbf{x} & \mathbf{x} & \mathbf{x} & \\ \mathbf{x} & & & \mathbf{x} \\ \mathbf{x} & & & \\ \mathbf{x} & & \mathbf{x} & \mathbf{x} \\ \mathbf{x} & & & \\ \mathbf{x} & & & \\ \mathbf{x} & \mathbf{x} & & \\ \mathbf{x} & \mathbf{x} & \mathbf{x} & \mathbf{x} \\ \mathbf{x} & & \mathbf{x} & \mathbf{x} \\ \mathbf{x} & \mathbf{x} & \mathbf{x} & \mathbf{x} \\ \mathbf{x} & & & \mathbf{x} \\ & & & \mathbf{x} & \\ & & & & \end{array}$

(n)

$\mathbf{X}$

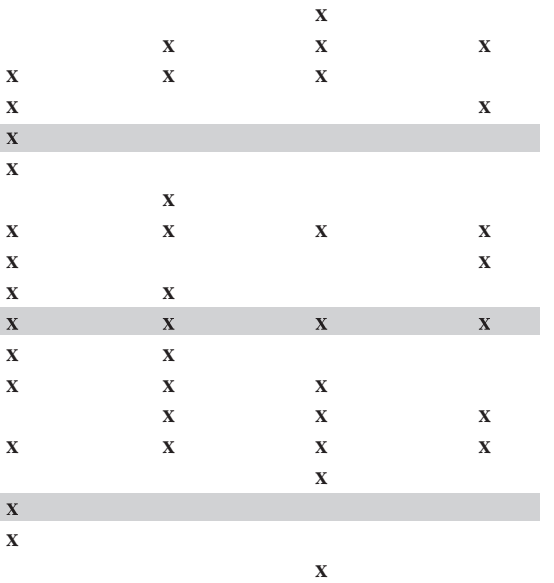

Downloaded From: https://bioone.org/journals/Western-North-American-Naturalist on 04 Sep 2019 
Table 1. Continued.

\begin{tabular}{|c|c|c|c|c|c|}
\hline \multirow[b]{2}{*}{ Taxon } & \multicolumn{5}{|c|}{ LACMIP locality number } \\
\hline & 326 & 327 & 329 & 42325,5068 & 42324 \\
\hline Neobernaya spadicea (Swainson, 1823) & & & & $\mathbf{x}$ & \\
\hline Norrisia norrisi (Sowerby I, 1838) & & $\mathbf{x}$ & $\mathbf{x}$ & $\mathbf{x}$ & \\
\hline Ocinebrina atropurpurea (Carpenter, 1865) & & & & $\mathbf{x}$ & \\
\hline Ocinebrina lurida (Middendorff, 1848) & & $\mathbf{x}$ & & $\mathbf{x}$ & \\
\hline Ocinebrina sp. & & $\mathbf{x}$ & & & $\mathbf{x}$ \\
\hline Odostomia lucca Dall \& Bartsch, 1909 & & $\mathbf{x}$ & & & \\
\hline Odostomia nota Dall \& Bartsch, 1909 & & $\mathbf{x}$ & & & \\
\hline Odostomia oregonensis (Dall \& Bartsch, 1907) & & $\mathbf{x}$ & & & \\
\hline Opalia borealis Keep, 1881 & & $\mathbf{x}$ & & & \\
\hline Perimangelia interfossa (Carpenter, 1864) & & $\mathbf{x}$ & & & \\
\hline Petaloconchus montereyensis Dall, 1919 & & & & $\mathbf{x}$ & \\
\hline Petaloconchus sp. & & $\mathbf{x}$ & & & \\
\hline Plesiocysticus politulus (Dall, 1919) & & $\mathbf{x}$ & $\mathbf{x}$ & & \\
\hline Pseudodiala acuta (Carpenter, 1864) & & $\mathbf{x}$ & & & \\
\hline Pseudomelatoma penicillata (Carpenter, 1864) & & & $\mathbf{x}$ & & \\
\hline PPseudomelatoma sp. & & & $\mathrm{x}$ & & \\
\hline Schwartziella californica (Bartsch, 1915) & & $\mathbf{x}$ & & & \\
\hline Seila montereyensis Bartsch, 1907 & & $\mathbf{x}$ & & & \\
\hline Siphonaria brannani Stearns, 1872 & & & & & $\mathbf{x}$ \\
\hline Tectura paleacea (Gould, 1853) & & $\mathbf{x}$ & & & \\
\hline Teinostoma supravallatum (Carpenter, 1864) & & $\mathbf{x}$ & & & \\
\hline Thylacodes squamigerus (Carpenter, 1857) & $\mathbf{x}$ & $\mathbf{x}$ & $\mathbf{x}$ & $\mathbf{x}$ & $\mathbf{x}$ \\
\hline Trimusculus reticulatus (Sowerby I, 1835) & & $\mathbf{x}$ & & & \\
\hline Triphora pedroana (Bartsch, 1907) & & $\mathbf{x}$ & $\mathbf{x}$ & & $\mathbf{x}$ \\
\hline Truncatella californica Pfeiffer, 1857 & & & $\mathbf{x}$ & & $\mathbf{x}$ \\
\hline Volvarina taeniolata Mörch, 1860 & & $\mathbf{x}$ & & & \\
\hline Xerarionta sp. [land snail] & & & & & $\mathbf{x}$ \\
\hline \multicolumn{6}{|l|}{ Bivalvia } \\
\hline Bernardina bakeri Dall, 1910 & & $\mathbf{x}$ & & & \\
\hline Chama arcana Bernard, 1976 & & & & $\mathbf{x}$ & \\
\hline Cumingia californica Conrad, 1837 & & & & $\mathbf{x}$ & $\mathbf{x}$ \\
\hline Epilucina californica (Conrad, 1837) & & $\mathbf{x}$ & $\mathbf{x}$ & $\mathbf{x}$ & $\mathbf{x}$ \\
\hline Glans carpenteri (Lamy, 1922) & & $\mathrm{x}$ & & $\mathbf{x}$ & $\mathrm{x}$ \\
\hline Grippina californica Dall, 1912 & & $\mathbf{x}$ & & & \\
\hline Lasaea adansoni (Gmelin, 1791) & & $\mathbf{x}$ & $\mathbf{x}$ & & \\
\hline PNutricola sp. & & $\mathbf{x}$ & & & \\
\hline Saxidomus sp. & & & & $\mathbf{x}$ & \\
\hline Septifer bifurcatus (Conrad, 1837) & & $\mathbf{x}$ & $\mathbf{x}$ & $\mathbf{x}$ & $\mathbf{x}$ \\
\hline PTrachycardium sp. & & $\mathbf{x}$ & & & \\
\hline indet. bivalve & & $\mathbf{x}$ & & & \\
\hline \multicolumn{6}{|l|}{ Polyplacophora } \\
\hline Callistochiton sp. & & $\mathbf{x}$ & & & \\
\hline Chaetopleura sp. & & $\mathbf{x}$ & & & \\
\hline Chiton plates & & $\mathbf{x}$ & $\mathbf{x}$ & & $\mathbf{x}$ \\
\hline Cryptochiton stelleri (Middendorff, 1847) & & & & $\mathbf{x}$ & \\
\hline Cyanoplax sp. & & $\mathbf{x}$ & & & \\
\hline Ischnochiton $\mathrm{sp}$. & & $\mathbf{x}$ & & & \\
\hline Mopalia sp. & & $\mathbf{x}$ & $\mathbf{x}$ & $\mathbf{x}$ & \\
\hline Nuttallina sp. & & $\mathbf{x}$ & & & \\
\hline \multicolumn{6}{|l|}{ ARTHROPODA } \\
\hline Barnacle fragments & & $\mathbf{x}$ & $\mathbf{x}$ & $\mathbf{x}$ & $\mathbf{x}$ \\
\hline Crab claws & & & $\mathbf{x}$ & & $\mathbf{x}$ \\
\hline \multicolumn{6}{|l|}{ ECHINODERMATA } \\
\hline Echinoid spines and plate & & & $\mathbf{x}$ & $\mathbf{x}$ & $\mathbf{x}$ \\
\hline \multicolumn{6}{|l|}{ CNIDARIa } \\
\hline Balanophyllia elegans Verrill, 1864 & & & $\mathbf{x}$ & & $\mathbf{x}$ \\
\hline \multicolumn{6}{|l|}{ ANNELIDA } \\
\hline Polychaete tube? & & & $\mathbf{x}$ & & \\
\hline \multicolumn{6}{|l|}{ VERTEBRATA } \\
\hline Fish bones & & & & & $\mathbf{x}$ \\
\hline
\end{tabular}


TABLE 2. Marine terrace fossils from West Anacapa Island, California.

\begin{tabular}{|c|c|c|c|}
\hline \multirow[b]{2}{*}{ Taxon } & \multicolumn{3}{|c|}{ LACMIP } \\
\hline & 42323,331 & 42322,331 & 42321 \\
\hline \multicolumn{4}{|l|}{ MOLLUSCA } \\
\hline \multicolumn{4}{|l|}{ Gastropoda } \\
\hline Acmaea mitra Rathke, 1833 & $\mathbf{x}$ & & \\
\hline Alia carinata (Hinds, 1844) & $\mathbf{x}$ & & \\
\hline Amphissa versicolor Dall, 1871 & & $\mathbf{x}$ & \\
\hline Amphissa sp. & $\mathbf{x}$ & & \\
\hline Antisabia panamensis (C.B. Adams, 1852) & $\mathbf{x}$ & & \\
\hline Barleeia haliotiphila Carpenter, 1864 & $\mathbf{x}$ & & \\
\hline Caecum californicum Dall, 1885 & $\mathbf{x}$ & & \\
\hline Californiconus californicus (Reeve, 1844) & $\mathbf{x}$ & $\mathbf{x}$ & \\
\hline Callianax biplicata (Sowerby I, 1825) & $\mathbf{x}$ & $\mathbf{x}$ & \\
\hline Chlorostoma gallina (Forbes, 1852) & $\mathbf{x}$ & & \\
\hline Crepidula perforans Valenciennes, 1846 & $\mathrm{x}$ & & \\
\hline Crepidula sp. & $\mathbf{x}$ & & \\
\hline Crossata californica (Hinds, 1843) & $\mathbf{x}$ & $\mathbf{x}$ & \\
\hline Discurra insessa (Hinds, 1842) & $\mathbf{x}$ & & \\
\hline Fissurella volcano Reeve, 1849 & $\mathbf{x}$ & $\mathbf{x}$ & \\
\hline Haliotis cracherodii Leach, 1814 & $\mathbf{x}$ & $\mathbf{x}$ & \\
\hline Haliotis rufescens (Swainson, 1822) & $\mathbf{x}$ & $\mathbf{x}$ & \\
\hline Haliotis sp. & $\mathbf{x}$ & $\mathbf{x}$ & $\mathbf{x}$ \\
\hline Harfordia kobelti & & $\mathbf{x}$ & \\
\hline Hima mendica (Gould, 1844) & & $\mathbf{x}$ & \\
\hline Hipponix tumens Carpenter, 1864 & & $\mathbf{x}$ & \\
\hline Lirobittium sp. & & $\mathbf{x}$ & \\
\hline Littorina sp. & $\mathbf{x}$ & & \\
\hline Lottia scabra (Gould, 1846) & $\mathbf{x}$ & & \\
\hline Lottia spp. & $\mathbf{x}$ & $\mathbf{x}$ & \\
\hline Mexacanthina lugubris (Sowerby I, 1822) & & $\mathbf{x}$ & \\
\hline Mitra idae Melvill, 1893 & $\mathbf{x}$ & $\mathbf{x}$ & \\
\hline Neobernaya spadicea (Swainson, 1823) & & $\mathbf{x}$ & \\
\hline Ocinebrina sp. & & $\mathbf{x}$ & \\
\hline Thylacodes squamigerus (Carpenter, 1857) & $\mathbf{x}$ & $\mathbf{x}$ & $\mathbf{x}$ \\
\hline \multicolumn{4}{|l|}{ Bivalvia } \\
\hline Chione californiensis (Broderip, 1835) & & $\mathbf{x}$ & \\
\hline Chlamys sp. & & $\mathbf{x}$ & \\
\hline Crassadoma gigantea (Gray, 1825) & $\mathbf{x}$ & $\mathbf{x}$ & \\
\hline Epilucina californica (Conrad, 1837) & $\mathbf{x}$ & & $\mathbf{x}$ \\
\hline Leopecten diegensis (Dall, 1898) & $\mathbf{x}$ & $\mathbf{x}$ & \\
\hline Leukoma sp. & $\mathbf{x}$ & & \\
\hline Mytilus californianus Conrad, 1837 & $\mathbf{x}$ & $\mathbf{x}$ & \\
\hline Ostrea lurida & & $\mathbf{x}$ & \\
\hline Pseudochama exogyra (Conrad, 1837) & $\mathbf{x}$ & & \\
\hline Saxidomus sp. & $\mathbf{x}$ & & \\
\hline Trachycardium quadragenarium (Conrad, 1837) & $\mathrm{x}$ & $\mathbf{x}$ & \\
\hline Tresus nuttallii (Conrad, 1837) & $\mathrm{x}$ & & \\
\hline \multicolumn{4}{|l|}{ Polyplacophora } \\
\hline Chiton plates & $\mathbf{x}$ & & \\
\hline \multicolumn{4}{|l|}{ ARTHROPODA } \\
\hline Barnacle fragments & $\mathbf{x}$ & $\mathbf{x}$ & \\
\hline Crab claws & $\mathbf{x}$ & & \\
\hline \multicolumn{4}{|l|}{ ECHINODERMATA } \\
\hline Echinoid spines and plates & $\mathbf{x}$ & $\mathbf{x}$ & \\
\hline \multicolumn{4}{|l|}{ ANNELIDA } \\
\hline \multicolumn{4}{|l|}{ Polychaeta } \\
\hline Indet. polychaete tube & & $\mathbf{x}$ & \\
\hline \multicolumn{4}{|l|}{ VERTEBRATA } \\
\hline Bones (bird and fish) & $\mathbf{x}$ & $\mathbf{x}$ & \\
\hline
\end{tabular}


Pliocene age (e.g., Groves 1991a, 1991b) and early and middle Pleistocene age (e.g., Woodring et al. 1946). In contrast, deposits of higher terraces on both islands do contain this taxon (Figs. 2, 3).

In addition to a simple correlation to the broader LIG period sensu lato (all of MIS 5), $\mathrm{D} / \mathrm{L}$ values in Chlorostoma permit an interpretation of two ages of fossils in the terrace deposits on both SBI and ANA. Fossils with higher D/L values fall within the $\sim 120$-ka aminozone whereas those with lower ratios fall within the $\sim 80-\mathrm{ka}$ aminozone (Figs. 11, 12a). Glutamic acid and valine $D / L$ values in Epilucina from SBI fall entirely within the -80-ka aminozone for this taxon (Fig. 13). Only three Epilucina shells were found on ANA, and although variability is high within this group, the mean value falls between the $\sim 120$-ka and $\sim 80$-ka aminozones (Fig. 13). Finally, values of $\mathrm{D}$-alloisoleucine to L-isoleucine in Chione from ANA and the Palos Verdes Sand in San Pedro fall along a linear northward-decreasing trend defined by this ratio in Chione from independently dated deposits of $\sim 120$ ka from elsewhere in California and Baja California (Fig. 12b). Therefore, amino acid values in Chione are interpreted to indicate that shells of this genus from ANA and the Palos Verdes Sand in San Pedro also date to the $\sim 120$-ka high-sea stand.

Results of Chlorostoma data from the Fraser Point area of westernmost Santa Cruz Island are more straightforward than results for the two small islands. Mean D/L values for both glutamic acid and valine fall clearly within the $\sim 120$-ka aminozone (Figs. 11, 12a). Although the Santa Cruz Island data indicate that the low terrace at Fraser Point correlates with the $\sim 120$ ka high-sea stand, the collective results from SBI and ANA indicate that two separate high-sea stands may be represented by the fossil assemblages in deposits on those islands. This apparently contradictory set of results can be examined in light of what is known about late Quaternary sea level history from both global and regional perspectives.

Much of our present understanding of eustatic sea level history in the late Quaternary comes from tectonically active (specifically uplifting) coasts located in far-field regions with respect to GIA processes. Studies going back several decades on Barbados (Broecker et al. 1968, Mesolella et al. 1969, Gallup et al.
1994, Edwards et al. 1997) and New Guinea (Bloom et al. 1974, Chappell et al. 1996, Cutler et al. 2003) show that constructional coral reef terraces on both coasts date to high-sea stands at $\sim 80 \mathrm{ka}, \sim 100 \mathrm{ka}$, and $\sim 120 \mathrm{ka}$, also represented in the marine oxygen isotope record of foraminifera as MIS 5.1, 5.3, and 5.5, respectively (Martinson et al. 1987). Assuming a constant uplift rate and a paleo-sea level of +6 $\mathrm{m}$ during the $\sim 120$-ka high-sea stand, the terrace studies from these far-field localities show that sea levels during the $\sim 100$-ka and $\sim 80$-ka high-sea stands were $\sim 15 \mathrm{~m}$ to $\sim 20 \mathrm{~m}$ below present.

On San Nicolas Island, California (Fig. 9), corals from the three lowest-elevation terraces date to $\sim 120 \mathrm{ka}(38-\mathrm{m}$ terrace), $\sim 120 \mathrm{ka}$ and $\sim 100 \mathrm{ka}$ (33-m terrace), and 80 ka (10-m terrace) based on U-series analyses by Muhs et al. $(2006,2012)$. Muhs et al. (2012) interpret the intermediate $33-\mathrm{m}$ terrace as representing the $~ 100$-ka high-sea stand, but that paleo-sea level was locally high enough to erode the outer part of the 38-m terrace and to rework fossils from its deposits into the deposits of the $\sim 100$-ka terrace. Similar results with a mix of $\sim 120$-ka corals and $\sim 100-\mathrm{ka}$ corals have been reported for a low terrace near Cayucos, San Luis Obispo County, California (Stein et al. 1991, Muhs et al. 2002a), and the Nestor terrace on Point Loma near San Diego, California (Ku and Kern 1974, Muhs et al. 2002a). Using the far-field sea level history with sea stands at $-15 \mathrm{~m}$ to $-20 \mathrm{~m}$ at $\sim 80 \mathrm{ka}$ and $\sim 100 \mathrm{ka}$, it is not possible for the $\sim 100$-ka high-sea stand to have submerged and eroded the $\sim 120$-ka terrace, even in areas with a low uplift rate, such as at Cayucos. Such a "capture" of a marine terrace dating to $\sim 120$ ka by the subsequent $\sim 100-$ ka sea stand would require a paleo-sea level much closer to the present than is indicated by the far-field paleo-sea level estimates.

Reconciliation of the vastly different estimates of paleo-sea level on the California coast from the far-field localities is possible by considering GIA processes. During a glacial phase and subsequent interglacial phase of a climate cycle, GIA-induced effects on sea level lead to departures from eustasy that have a complex geometry and history. In near-field or intermediate-field localities, the differences in apparent sea level history compared to farfield localities can be significant. A dramatic 
example of GIA effects on apparent sea level history can be found along the Atlantic Coastal Plain of the United States and the island of Bermuda to the east. Compared to Barbados, well to the south, the Atlantic Coastal PlainBermuda region is situated much closer to where the former Laurentide ice sheet of North America advanced during the past two glacial periods (MIS 2 and 6). Thus, even though the Atlantic Coastal Plain and Bermuda are considered to be tectonically stable, $\sim 80$-ka (MIS 5.1) marine deposits are well dated and are found there at elevations of a meter to a few meters above present sea level (Muhs et al. 2002b, Wehmiller et al. 2004). Potter and Lambeck (2003) explain these higher-thanexpected elevations at northern localities to be the result of GIA effects, which are minimal on Barbados but increase slightly moving northward to the Florida Keys and increase dramatically at the Atlantic Coastal Plain of the United States and the island of Bermuda.

Coastal California, though not near large ice sheets during the last glacial period, is situated within an intermediate field region of North America where GIA effects are still expected to be significant because the region is on a continent that hosted large ice sheets. Modeling of GIA effects for San Nicolas Island (and applicable elsewhere on the California coast) by J.X. Mitrovica (in Muhs et al. 2012) shows that both the $\sim 80$-ka (MIS 5.1) and $\sim 100$-ka (MIS 5.3) sea stands are predicted to record higher relative paleo-sea levels on the California coast than on far-field coastlines. The geologic record of high-sea stands from terraces $1(\sim 10 \mathrm{~m}), 2 \mathrm{~b}(\sim 33 \mathrm{~m})$, and $2 \mathrm{a}$ $(\sim 38 \mathrm{~m})$ dated to $\sim 80 \mathrm{ka}, \sim 100 \mathrm{ka}+120 \mathrm{ka}$, and $120 \mathrm{ka}$, respectively, on San Nicolas Island agree with the GIA model results. Thus, paleo-sea level estimates for the southern California coast are, relative to present, $-11 \mathrm{~m}$ to $-12 \mathrm{~m}$ at $\sim 80 \mathrm{ka}$ and $+2 \mathrm{~m}$ to $+6 \mathrm{~m}$ at $\sim 100 \mathrm{ka}$ (Muhs et al. 2012). With these higher sea level estimates, it is not difficult to envision how a high-sea stand at $\sim 100 \mathrm{ka}$ could overtake at least the outer part of a $\sim 120$-ka marine terrace in a tectonically stable area or even an area with a modest uplift rate. The evidence cited earlier of mixes of $\sim 100$-ka and $\sim 120$-ka corals from single terraces at Cayucos (San Luis Obispo County), Point Loma (San Diego County), and San Nicolas Island, California, supports the interpretation that such a sequence of events occurred during the LIG complex.

Nevertheless, amino acid data reported here present a potential problem: $\mathrm{D} / \mathrm{L}$ values in both Chlorostoma and Epilucina imply that the younger population of mollusks in the deposits of SBI and ANA could correlate to the $~ 80-k a$ high-sea stand. Even with a sea level as high as 11-12 m below the present at $\sim 80 \mathrm{ka}$, it is not likely that the younger highsea stand would overtake even the outer edge of a marine terrace dated to $\sim 120 \mathrm{ka}$ that has experienced uplift (even at a modest rate) for some $40 \mathrm{ka}$. Furthermore, such a scenario would also require complete erosion of any terrace that formed during the $\sim 100 \mathrm{ka}$ (MIS 5.3) high-sea stand.

A simpler explanation is that the younger groups of shells on both SBI and ANA actually date to the $~ 100$-ka high-sea stand and that D/L values in Chlorostoma and Epilucina may not always be able to discriminate between shells that are $\sim 80 \mathrm{ka}$ and $\sim 100 \mathrm{ka}$. There are two possible reasons for this lack of discriminating ability. First, there is only a 20 ka difference in age between these two high-sea stands, which may not be a sufficient time period for significant additional racemization. Second, in southern California the period between these two high-sea stands (MIS 5.2, or $5 \mathrm{~b}$, at $\sim 95-85 \mathrm{ka}$ ) likely was relatively cool, not only in the ocean (Kennett and Venz 1995) but on land as well (Heusser 2000). Thus, racemization and epimerization rates during this period were likely commensurately lower (see discussion in Wehmiller 2013a, pp. 7-9). Thus, the preferred interpretation is that on both SBI and ANA, Chlorostoma and Epilucina shells with higher $\mathrm{D} / \mathrm{L}$ glutamic acid and valine values and higher D-alloisoleucine/ L-isoleucine values correlate with the $\sim 120$-ka high-sea stand and those with lower values correlate with the $\sim 100$-ka high-sea stand. This interpretation is consistent with those made from terrace deposits containing a mixture of $\sim 100$-ka and $\sim 120$-ka corals at Cayucos, California, and on Point Loma and San Nicolas Island, California (Muhs et al. 2002a, 2012).

\section{Identification of Extralimital and Southward- \\ Ranging and Northward-Ranging Species}

If two high-sea stands are represented in the deposits of the 11-m-high terraces of SBI 
and ANA, there are implications for what should be expected with regard to the thermal aspects of the terrace faunas. Ocean Drilling Project (ODP) site 893A in the Santa Barbara Basin (Fig. 1) has one of the most complete planktonic foraminiferal records of marine paleoclimate off southern California. The site is very close to ANA and therefore should record paleoceanographic conditions that affected the island. The record at site 893A goes back to $\sim 160 \mathrm{ka}$, well past the peak of the LIG at $\sim 120 \mathrm{ka}$ (Kennett 1995, Kennett and Venz 1995, Hendy 2010). Planktonic foraminifera from this core show that conditions as warm as or warmer than the present can be identified by the abundance of dextral-coiled Neogloboquadrina pachyderma (now referred to as N. incompta; see Hendy 2010), one of the dominant species living today in the Santa Barbara Basin. Neogloboquadrina incompta prefers water temperatures warmer than $\sim 10{ }^{\circ} \mathrm{C}$ (Kennett and Venz 1995). In waters cooler than $\sim 10{ }^{\circ} \mathrm{C}$, the sinistral-coiled taxon N. pachyderma increases in abundance; this species is dominant in water temperatures cooler than $\sim 6{ }^{\circ} \mathrm{C}$. In addition to $N$. incompta, there are four other warm-water species that are useful for paleoclimatic interpretations in the eastern Pacific Ocean: Globigerinoides ruber, Neogloboquadrina dutertrei, Globorotalia inflata, and Orbulina universa (Kennett and Venz 1995).

These warm-water indicators in the Santa Barbara Basin record show that MIS 1 (the Holocene) and MIS 5.5 ( $120 \mathrm{ka})$ are by far the two warmest periods of the past $\sim 160 \mathrm{ka}$, with high abundances of $N$. incompta and other warm-water forms (Kennett and Venz 1995). Glacial periods represented by MIS 6, 4 , and 2 generally show low abundances of N. incompta. The records for MIS $5.3(\sim 100 \mathrm{ka})$ and MIS 5.1 ( $~ 80 \mathrm{ka})$, however, also show very low abundances of $N$. incompta, indicating that although sea level was relatively high compared to full-glacial periods or even interstadial periods, water temperatures were generally cool. Elsewhere on the Channel Islands and mainland California, faunas from deposits dated to MIS 5.1 ( $~ 80 \mathrm{ka})$ include a number of extralimital northern or northward-ranging species (Kern 1977, Kennedy et al. 1982, Muhs et al. 2002a, 2006, 2012), whereas deposits with fossils dated solely to MIS $5.5(\sim 120 \mathrm{ka})$ contain a number of extralimital southern or southward-ranging species (Lindberg et al. 1980, Rockwell et al. 1989, Muhs et al. 2002a, 2012). These observations are consistent with the planktonic foraminiferal record of the Santa Barbara Basin. Because of GIA effects, however, a number of low-uplift-rate localities in central and southern California (Cayucos, Point Loma, and San Nicolas Island) contain corals with both MIS $5.3(\sim 100 \mathrm{ka})$ and MIS $5.5(\sim 120 \mathrm{ka})$ ages and host molluscan faunas that have species with both northern and southern aspects. Still other localities (Newport Bay, San Miguel Island, Santa Rosa Island, and San Clemente Island) have yielded only $\sim 120$-ka coral ages but are suspected to have fossils dating to $\sim 100 \mathrm{ka}$ based on low uplift rates for these islands and molluscan faunas that host both northern and southern forms (Kanakoff and Emerson 1959; Muhs et al. 2014a, 2014b). With the amino acid evidence that the low terraces on SBI and ANA contain fossils that could date to both the 100-ka and -120-ka high-sea stands, fossils with both northern $(\sim 100 \mathrm{ka})$ and southern $(\sim 120 \mathrm{ka})$ affinities are expected in these deposits.

This hypothesis was tested by examining the geographic ranges of all species found in the terrace faunas whose range endpoints fall close to the latitudes of the two islands. Results indicate that on SBI, a large number of species in deposits of the first marine terrace are presently found primarily or entirely to the south of the island and are thus considered southward-ranging or extralimital southern species (Fig. 15a). Two species of gastropods, Schwartziella californica and Mexacanthina lugubris, have modern northern range endpoints to the south of SBI and thus are true extralimital southern species. Schwartziella californica is apparently a rare species, both in the fossil record and at present. Modern specimens of this taxon have been found only on Santa Catalina Island, California; around Islas Coronados, Baja California (Bartsch 1915); and around Isla de Guadalupe (Chace 1958). The occurrence of Mexacanthina lugubris is not unusual in the fossil record of southern California (see review in Muhs et al. 2002a), but SBI is well north of its modern northern range endpoint. Indeed, M. lugubris is rarely found as far north as San Diego (Radwin 1974). Issues related to the modern zoogeography of this taxon are discussed in more detail later, but Bertsch and Aguilar Rosas 


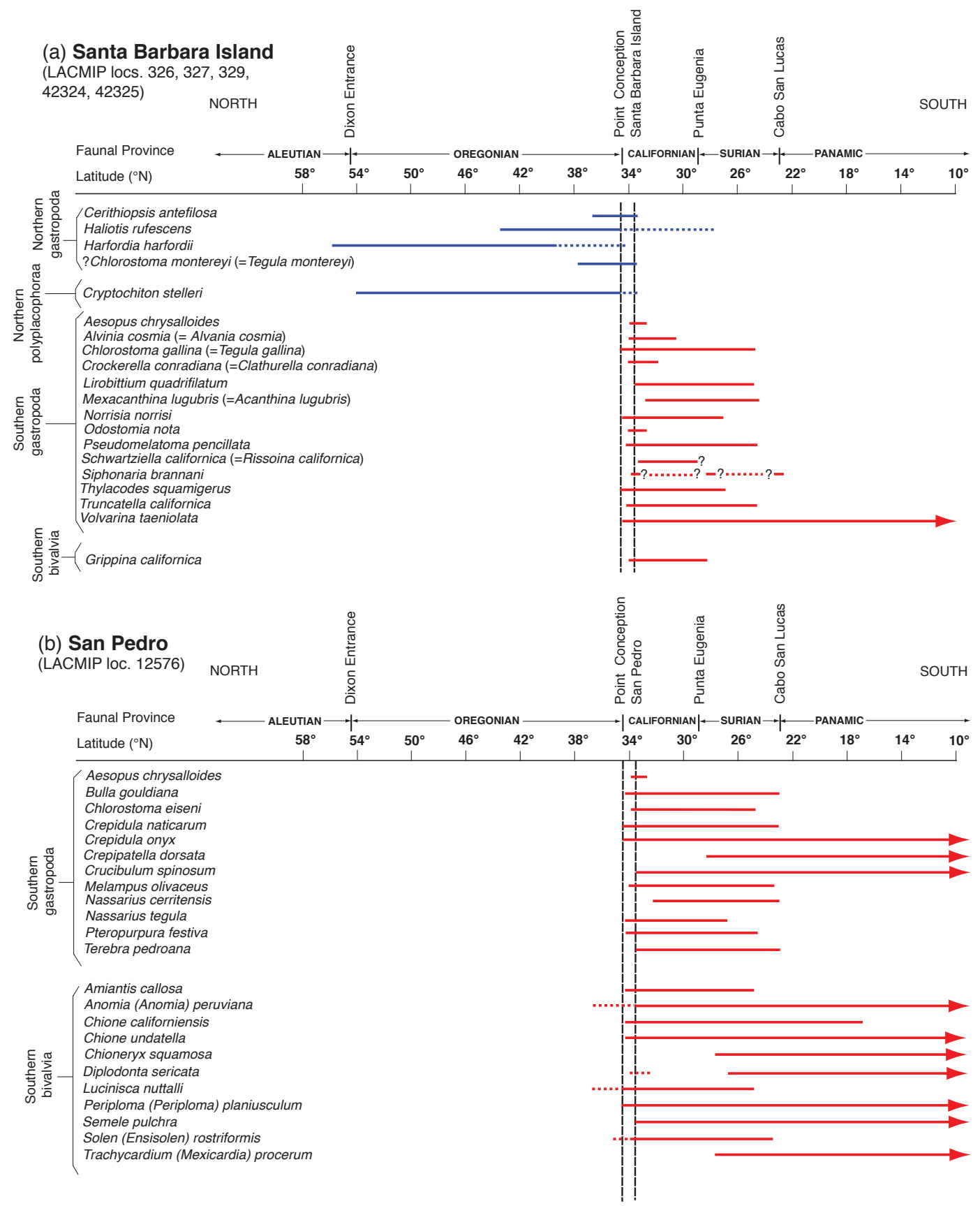

Fig. 15. North-south latitudinal plot showing marine invertebrate faunal provinces (Valentine 1966) and modern ranges of fossils with paleozoogeographic significance found in the terrace deposits on (a) Santa Barbara Island and (b) in the Palos Verdes Sand at LACMIP locality 12576 in San Pedro, Los Angeles County, California. Dashed lines indicate latitudinal reaches where a given taxon has been reported but only uncommonly. See text for sources of geographic range information. See Fig. 12 for the location of LACMIP locality 12576 in San Pedro, California. 
(2016) report that $M$. lugubris presently lives on the Pacific Coast from San Diego to Cabo San Lucas and on the eastern Golfo de California coast from Bahía Kino, Sonora, to Mazatlán, Sinaloa. Based on this very recent reference, $M$. lugubris is interpreted as an extralimital southern species with respect to its occurrence on SBI.

There are a number of southward-ranging species on SBI. These include the bivalve Grippina californica and the gastropods Aesopus chrysalloides, Alvinia cosmia, Bittium quadrifilatum, Crockerella conradiana, Odostomia nota, Pseudomelatoma pencillata, Thylacodes squamigerus, Siphonaria brannani, and Truncatella californica. McLean (2007) pointed out that members of the Siphonariid family, such as Siphonaria brannani, occur mostly in tropical waters. Interestingly, although $S$. brannani has a living population around SBI today, the species has not been reported around the other Channel Islands or mainland localities in southern California (Littler 1980). The species has been reported as far south as Islas San Benito $\left(\sim 28.3^{\circ} \mathrm{N}\right)$, Baja California (CAS-IZ 6128.00), and may have, until recently, lived as far south as Cabo San Lucas, Baja California Sur (Keen 1971). It is possible, therefore, that S. brannani has a southward-ranging but disjunct distribution. Three other species of gastropods (Chlorostoma gallina, Norrisia norrisii, and Volvarina taeniolata) have modern northern range endpoints a short distance north of SBI at Point Conception, Santa Barbara County (Fig. 1b), and also can be considered southward-ranging species.

In addition to the warm-water forms described above, the first terrace on SBI also contains a number of cool-water forms (Fig. 15a). In collections made by Lipps et al. (1968) and reexamined in the present study, as well as in new collections, specimens of the gastropod Cerithiopsis antefilosa were found. This species presently lives only as far south as SBI. Two other taxa, the gastropod Haliotis rufescens and the chiton Cryptochiton stelleri, have southern range endpoints south of SBI, but both taxa are only rarely found south of Point Conception and can be considered northwardranging species. A fourth northward-ranging species, Chlorostoma montereyi, was reported as a fossil on SBI by Lipps et al. (1968), but this could not be confirmed in the present study. If this species is indeed present among the fossil assemblages of the first terrace on $\mathrm{SBI}$, it is also a cool-water indicator. Chlorostoma montereyi has a present range from Bolinas Bay, Marin County, California, to SBI (Abbott and Haderlie 1980), but possibly also to San Pedro (LACM 57941) and San Nicolas Island (LACM 147862). However, Chlorostoma montereyi is only rarely found south of Point Conception. Finally, Harfordia harfordii is an extralimital northern species of gastropod from the first terrace on SBI. Based on museum records, this species has a modern distribution from Hope Island, British Columbia (Abbott 1974), south to Cormorant Cove, Mendocino County, California (LACM 944.30). There are very few fossil occurrences of this extralimital northern species, but it is reported in deposits of the $\sim 120$-ka marine terrace of San Miguel Island (Muhs et al. 2014a) and the $~ 80$-ka terrace of San Nicolas Island (Muhs et al. 2012).

There are fewer extralimital or southwardranging species of mollusks in deposits of the 11-m terrace on West Anacapa Island. The lowterrace deposits on this island host the aforementioned Mexacanthina lugubris, a distinctly extralimital southern species. Southwardranging species include Chlorostoma gallina and Thylacodes squamigerus, which are also found on SBI as noted above, and the bivalve Chione californiensis, also reported by Lipps (1964). Chione californiensis is one of three species of this genus that occur in southern California. Chione is typically a tropical genus and all three species that occur in southern California are at their northernmost modern limit in the vicinity of Santa Barbara, California, very close to West Anacapa Island (Coan et al. 2000, Coan and Valentich-Scott 2012). Another southward-ranging species is the gastropod Harfordia kobelti, which, based on LACM records, is found only from Santa Rosa Island south to Cortes Bank, 80 km southwest of San Clemente Island. The only coolwater form found on West Anacapa Island is the northward-ranging species Haliotis rufescens, also found on SBI.

\section{Hypotheses for the Origin of Thermally Anomalous Faunas}

The mix of species with cool-water, northern affinities and warm-water, southern affinities within the same deposit on SBI (and to a lesser degree on West Anacapa Island) is an 
example of what have been referred to as "thermally anomalous" faunas. Thermally anomalous faunas have been recognized in Quaternary marine deposits along the Pacific Coast of North America for more than a century. Roy et al. (1995) and Muhs et al. (2014b) review various hypotheses that have been proposed to explain these mixes of fossils. These include mechanisms such as changes in water temperatures over time, fossil reworking, species competition, upwelling, storm wave transport, changes in coastal geography, physiological changes in species, temporary current changes, and greater seasonality.

An additional explanation for thermally anomalous faunas on the Channel Islands is that the fossils date to a single interglacial period but that the assemblage as a whole represents a long period within that interglacial, including a period of peak warmth and a later period when cooling had begun but sea level had not yet fallen. This explanation was offered for the mix of extralimital-southern "Senegalese" species and extralimital-northern Mediterranean species coexisting in marine deposits dated to MIS $5.5(\sim 120 \mathrm{ka})$ on the Canary Islands (Muhs et al. 2014c). In this orbitally forced scenario for the eastern Atlantic Ocean, higher insolation early in the LIG period brought about not only direct warming but also a northward migration of the intertropical convergence zone, decreased trade winds, and decreased upwelling. The resultant warm ocean temperatures around the Canary Islands therefore allowed migration of the tropical Senegalese species northward. Later within the same interglacial period, diminished insolation brought about decreased direct warming, southward migration of the intertropical convergence zone, reestablishment of the trade winds, and upwelling. The cooler ocean temperatures resulting from this brought about local extinction of the Senegalese fauna and allowed southward migration of Mediterranean species.

There are some similarities between the Channel Islands and the Canary Islands, so it is pertinent to consider whether the explanation for the LIG fossil record on the Canary Islands could also apply to the Channel Islands. Both island chains are in the subtropics and are influenced by cold, southward-moving, eastern boundary currents (the California Current and the Canaries Current). The sce- nario above, however, attractive as it sounds for its simplicity, does not explain the D/L values in mollusks (this study) or the U-series ages of corals (Muhs et al. 2002a, 2012) that indicate two ages of fossils in marine terrace deposits in California. Furthermore, while GIA modeling indicates that higher relative sea levels and fossil mixing are expected in California and on other North American coastlines, they are not expected in the farther-field location of the Canary Islands (see Fig. 1 and Table 1 in Creveling et al. 2015).

The preferred interpretation is that two groups of fossils of different ages are represented on SBI and ANA, one deposited during an early warm period $(\sim 120 \mathrm{ka})$ and the other deposited during a later cool period ( $\sim 100 \mathrm{ka})$. The $\sim 100$-ka high-sea stand, if it was above present sea level as GIA modeling suggests, would have reworked the $\sim 120$-ka fossils into the younger deposits. This explanation is consistent with other localities in central and southern California where $\sim 100$-ka and $\sim 120$-ka corals within the same deposit also host mollusks with northern and southern affinities.

\section{Rocky Intertidal Faunas versus Protected Bay Faunas during the Last Interglacial Period}

As discussed above, the faunas from both SBI and (to a lesser degree) ANA have a species composition that is typical of exposed, rocky-shore intertidal environments. Kennedy (2000) points out that marine deposits of LIG age in more protected bay environments could have been more favorable environments for warm-water mollusks and therefore could host more extralimital southern species and southward-ranging species. This hypothesis was tested by examining the record of fossils recovered at the Palos Verdes Sand locality in San Pedro (Fig. 14; LACMIP loc. 12576) and archived at LACMIP. Based on D/L values in Chione discussed earlier (and amino acid data on Leukoma staminea in Muhs et al. 1992), the deposits at this locality are the same age as the older (MIS 5.5) deposits on ANA and SBI. From our examination of the Palos Verdes Sand deposit in the field $\left(33^{\circ} 45.89790^{\prime} \mathrm{N}\right.$, $118^{\circ} 16.94856^{\prime} \mathrm{W}$; elevation $\sim 13 \mathrm{~m}$ ), it seems likely that the marine sediments were laid down in a protected bay type of setting. In contrast to the poorly sorted marine terrace sands and gravels that are typical of rocky intertidal environments on the high-energy 
coasts of the Channel Islands, the deposits at LACMIP loc. 12576 consist of $\sim 10$ m of clean well-sorted sands, indicative of quiet-water bay sedimentation. Santa Barbara Island and San Pedro are situated at similar latitudes (Fig. lb), allowing a direct comparison of fossil faunas from exposed, rocky intertidal environments (SBI) to those from protected, quietwater bay environments (San Pedro).

The paleozoogeography of the fossils from LACMIP loc. 12576 (Fig. 15b) was determined based on modern species ranges after an examination of the fossils archived at LACMIP. There are no extralimital northern species nor even any northward-ranging species at this San Pedro locality. There are, however, several extralimital southern species and a large number of southward-ranging species. Extralimital southern gastropods at LACMIP loc. 12576 include Nassarius cerritensis, which today lives only on the outer Baja California coast and in the Golfo de California (Keen 1971), and Crepipatella dorsata, which today lives only from Isla Cedros, Baja California, to Chile (LACM collections and Keen 1971). Extralimital southern bivalves include Trachycardium (Mexicardia) procerum, which ranges from the Golfo de California and Oaxaca, Mexico, to Chile (Keen 1971); Diplodonta sericata, which has been reported from Santa Cruz Island and San Diego but likely only has permanent populations from Laguna San Ignacio, Baja California Sur, to Tumbes, Peru (Coan et al. 2000); and Chioneryx squamosa (formerly Chione picta), which ranges from Baja California Sur's Pacific Coast (northern limit at Laguna Ojo de Liebre, $27.8^{\circ} \mathrm{N}$ ) through the Golfo de California and south to Peru (Coan and ValentichScott 2012). In addition, another half-dozenor-so species in this collection today range no farther north than Los Angeles, California, and about a dozen more species today range no farther north than Santa Barbara or Point Conception (Fig. 15b). We agree with Kennedy (2000) that it seems likely that protected, quiet-water bay environments such as northern San Pedro provided particularly favorable settings for the northward migration of southern species of mollusks, whereas the rocky intertidal environments of the Channel Islands apparently provided less favorable environments. The reason for this intriguing difference is unknown but may be a fruitful area for further research.
Regional Evidence of Last Interglacial Warming and the Issue of Thermal Expansion

Earlier in this paper, thermal expansion was mentioned as a mechanism that explains at least a part of the higher sea level during MIS 5.5 (Turney and Jones 2010, McKay et al. 2011). McKay et al. (2011) concluded that on a global scale, SST during MIS 5.5 was not significantly different from the present. These investigators inferred that thermal expansion likely played only a minor role, if any, in the higher-than-present sea level during MIS 5.5. However, as the same investigators also pointed out, some regions are exceptions to this generalization. Examples were cited from the shallow-marine molluscan and coral fossil record of warmer-than-present waters during the LIG from Australia, Alaska, California, Hawaii, and the eastern Atlantic Ocean and Mediterranean. If the interpretation is correct that the southern species on SBI and ANA date to the $\sim 120$-ka high-sea stand, it is interesting to examine the regional context of these records. Two examples are offered here, the occurrence of Chione californiensis (as well as other species of this genus) and Mexacanthina lugubris on ANA and SBI. Two maps are presented, one for each taxon, showing the modern ranges and the fossil occurrences of each taxon in deposits dated to the $\sim 120-\mathrm{ka}$ high-sea stand either by U-series on coral or amino acids on mollusks (Fig. 16).

At present, Chione californiensis, C. undatella, and C. fluctifraga live mainly in the warm, tropical-to-subtropical Golfo de California waters and south along the Mexican mainland and extend north only a limited distance along the Pacific Coast of California, with the Santa Barbara area as the modern northern range endpoint for all three species (Coan et al. 2000, Coan and Valentich-Scott 2012). Fossil occurrences of Chione dating to $\sim 120 \mathrm{ka}$ are found in the Golfo de California, along the Pacific coast of Baja California, and at several localities in southern California including ANA (this study), where it is very close to its northern limit, and San Miguel Island (Muhs et al. 2014a), which is just beyond its northern limit. Farther north, a marine terrace dated to $\sim 120 \mathrm{ka}$ in San Luis Obispo County is reported to host Chione undatella (Kennedy 2000). Because specific localities were not given in Kennedy (2000), we visited a locality in San Luis Obispo 
(a)

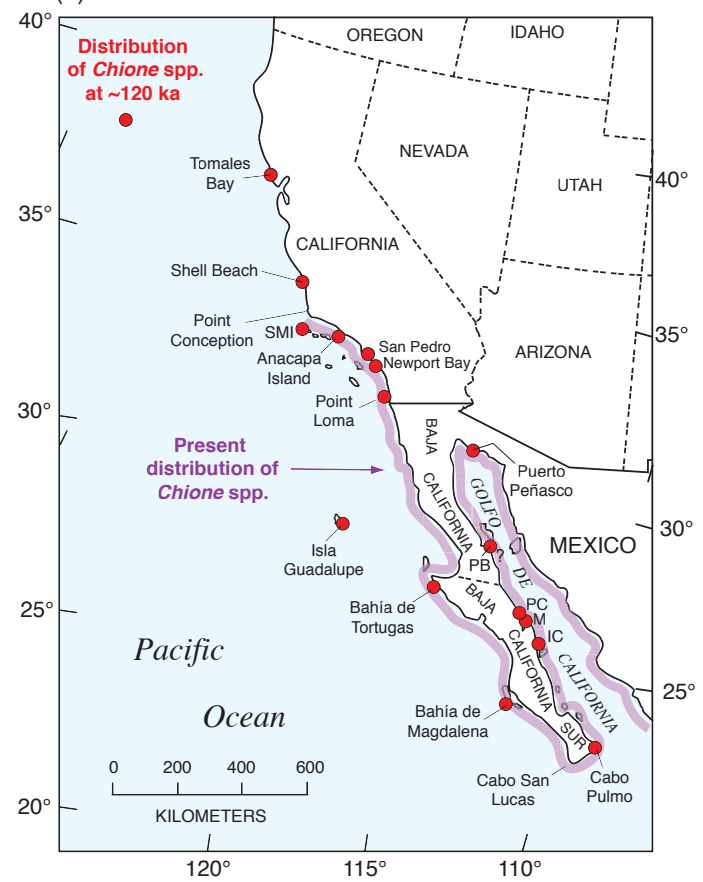

(b)

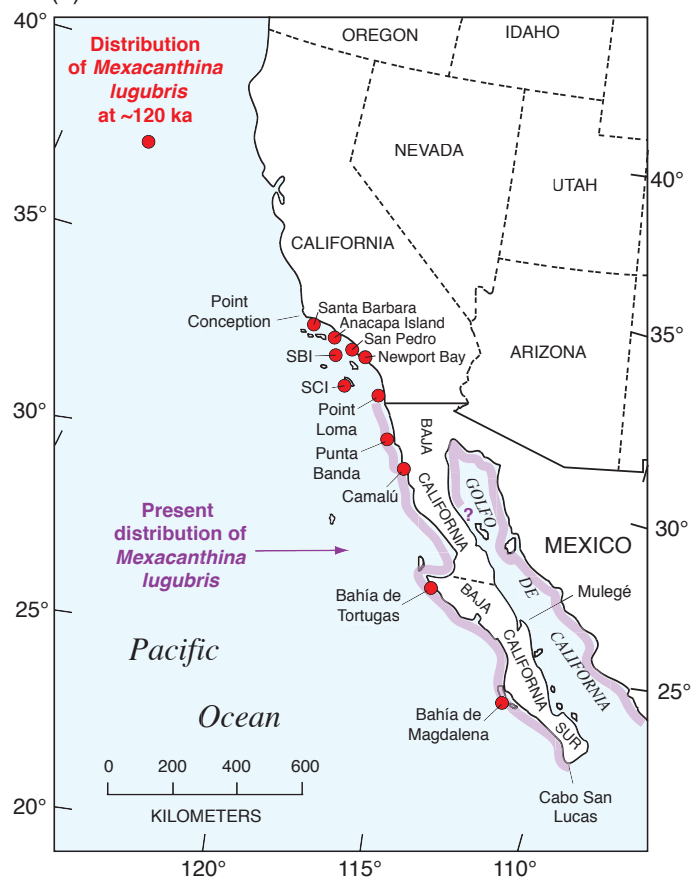

Fig. 16. Map of southern California and Baja California showing the modern northern limits of 2 warm-water taxa, (a) Chione spp. and (b) Mexacanthina lugubris, and terrace deposits containing these species that date or probably date to $\sim 120 \mathrm{ka}$. See text for sources of modern limits.

Terrace faunas of last-interglacial age that contain Chione spp. (a) are from the following sources. (1) Tomales Bay: faunal data (C. undatella) from Johnson (1962) and this study; age data from Grove et al. (1995) and this study. (2) San Luis Obispo area: faunal data (C. undatella) from Kennedy (2000); age data from Muhs et al. (1994). (3) San Miguel Island (SMI): faunal (Chione sp.) and age data from Muhs et al. (2014a). (4) Anacapa Island: faunal data (C. californiensis) from Lipps (1964) and this study; age data from this study. (5) San Pedro (Palos Verdes Sand at LACMIP locality 12576): faunal (C. californiensis, C. undatella, and C. picta) and age data from this study. (6) Newport Bay: faunal data (C. californiensis, C. undatella, C. fluctifraga, C. picta, C. gnidia, and C. cortezi) from Kanakoff and Emerson (1959); age data from Grant et al. (1999). (7) Point Loma: faunal data (C. californiensis) from Kern (1977); age data from Muhs et al. (2002a). (8) Isla Guadalupe: faunal data (C. squamosa) from Lindberg et al. (1980); age data from Muhs et al. (2002a). (9) Bahía de Tortugas: faunal data (C. californiensis, C. picta, and C. gnidia) from Emerson (1980); age data from Emerson et al. (1981). (10) Bahía de Magdalena: faunal data (Chione spp.) from Jordan (1936); age data from Omura et al. (1979). (11) Cabo Pulmo: faunal data (C. californiensis) from Squires (1959); age data from Muhs et al. (2002a). (12) Isla Coronados (IC): faunal data (C. californiensis) from M.E. Johnson (written communication 17 February 2017); age data from Johnson et al. (2007) and Muhs et al. (2014a). (13) Mulegé (M): faunal data (Chione sp.) from Ortlieb (1987); age data from Ashby et al. (1987). (14) Punta Chivato (PC): faunal data (C. californiensis) from Johnson et al. (2007); age data from Johnson et al. (2007) and Muhs et al. (2014a). (15) Punta Ballena (PB): faunal data (C. californiensis) from Johnson et al. (2017), with tentative age assignment to the last interglacial period by the authors of this paper. (16) Puerto Peñasco: faunal and age data from the present study, but also see Davis et al. (1990); Chione samples used in the present study were collected by Nicholas Lancaster

Terrace faunas of last-interglacial age that contain Mexacanthina lugubris (b) are from the following sources. (1) Santa Barbara area: age and faunal data from Kennedy et al. (1992). (2) Anacapa Island: faunal and age data from this study. (3) San Pedro area: faunal data from Valentine (1962); age data from Muhs et al. (1992). (4) Santa Barbara Island (SBI): faunal data from Lipps et al. (1968) and this study; age data from this study. (5) Newport Bay: faunal data from Kanakoff and Emerson (1959); age data from Grant et al. (1999). (6) San Clemente Island (SCI): faunal data from Muhs et al. (2014b); age data from Muhs et al. (2002a). (7) Point Loma: faunal data from Kern (1977); age data from Muhs et al. (2002a). (8) Punta Banda: faunal data from Rockwell et al. (1989) and Muhs et al. (2002a); age data from Muhs et al. (2002a). (9) Camalú: faunal data from Valentine (1980); age data from Valentine (1980) and Wehmiller and Pellerito (2015). (10) Bahía de Tortugas: faunal and age data from Emerson et al. (1981). (11) Bahía de Magdalena: faunal data from Jordan (1936); age data from Omura et al. (1979). (12) Mulegé (M): faunal data from Ortlieb (1987); age data from Ashby et al. (1987). 
County, Shell Beach, where Stein et al. (1991) reported three $\mathrm{U}$-series ages on coral of $\sim 120 \mathrm{ka}$ for a terrace whose outer edge is $\sim 20 \mathrm{~m}$ above modern sea level. Using the U-series data on coral in Stein et al. (1991), ages were recalculated to be $121.6 \pm 1.8 \mathrm{ka}, 122.5 \pm 2.0 \mathrm{ka}$, and $126.7 \pm 3.4 \mathrm{ka}$ for their Shell Beach samples MS-40, 41, and 43, respectively, using the new half-lives reported in Cheng et al. (2013). At the Shell Beach locality $\left(35^{\circ} 09^{\prime} 09.5^{\prime \prime} \mathrm{N}\right.$, $120^{\circ} 39^{\prime} 40.2^{\prime \prime} \mathrm{W}$ ), we collected molluscan fossils and found Chione sp. among the taxa, confirming the presence of this genus in San Luis Obispo County during the LIG period. Still farther north, Chione undatella is reported to be in the Millerton Formation marine deposits (Johnson 1962) where they are exposed along the shores of Tomales Bay (Fig. 1a). The presence of this species in the Millerton Formation along Tomales Bay was also confirmed by our collections. As discussed earlier, Grove et al. (1995) reported that luminescence dating indicates that the Millerton Formation is of MIS 5.5 age. Thus, the occurrences of Chione in marine deposits of LIG age on ANA and San Miguel Island-though these fossils are at or only slightly beyond the modern limits-are part of an even more extensive LIG northward migration of this genus, close to $500 \mathrm{~km}$ north of its modern northern range endpoint.

The other example offered here is for the gastropod Mexacanthina lugubris and represents a revision of what was reported in an earlier paper (Muhs et al. 2014b). In the previous paper, a map was presented indicating that this species currently lives from San Diego (Hertz 1995) south along the coast of Baja California and throughout the Golfo de California. This was based in part on range limits given by Keen (1971) for the Pacific Coast of Baja California and in part on collections from the Golfo de California archived at LACM (localities at Bahía San Luis Gonzaga, Isla Tiburón, and San Felipe, all in the upper part of the Golfo de California) and the Museum of Comparative Zoology at Harvard University (localities at San Luis Gonzaga and northwest of Puerto Peñasco, also in the upper gulf region). Early studies by Steinbeck and Ricketts (1941) also reported M. lugubris from the Golfo de California. Studies of DNA by Marko and Vermeij (1999) indicate that what they refer to as M. lugubris lugubris (on the Pacific Coast of Baja California) and M. lugubris angelica (in the Golfo de California) could be two distinct species. Fenberg et al. (2014) did not consider M. lugubris lugubris to be present in the Golfo de California and thought that all occurrences of this genus in that region were M. lugubris angelica. In collections at LACM, however, these two forms are archived separately. They are also distinguished from one another in the recent volume on marine invertebrates by Bertsch and Aguilar Rosas (2016) who report that $M$. lugubris presently lives from San Diego to Cabo San Lucas on the Pacific Coast and from Bahía Kino, Sonora (latitude $28.8^{\circ} \mathrm{N}$ ), to Mazatlán, Sinaloa (latitude $23.2^{\circ} \mathrm{N}$ ), on the eastern Golfo de California coast. We have used this distribution along with specimen localities at LACM and the Museum of Comparative Zoology at Harvard University to generate a new range map. It is important to note that the modern range of Mexacanthina lugubris may have expanded slightly north of San Diego in the past few decades (see discussion in Fenberg et al. 2014). Fossil occurrences of Mexacanthina lugubris in deposits dated to $\sim 120 \mathrm{ka}$ are found all along this taxon's modern Pacific Coast distribution from Bahía de Magdalena, Baja California Sur, to Point Loma near San Diego. The two occurrences reported here for SBI and ANA, however, are $\sim 200 \mathrm{~km}$ and $\sim 250 \mathrm{~km}$ north, respectively, of the modern range endpoint for $M$. lugubris. Only one other LIG fossil of this taxon, which was found along the coast west of Santa Barbara, is known to be farther north (Kennedy et al. 1992). Although warmer waters during the LIG period allowed Chione to migrate north of its modern range by several hundred kilometers, Point Conception was apparently a barrier to northward migration of $M$. lugubris beyond the Santa Barbara region.

In contrast to McKay et al. (2011), the observations made here from both high-energy rocky-shore environments (at SBI and ANA) and a protected, quiet-water bay environment (San Pedro) indicate that the Pacific Coast of Baja California and California likely experienced a SST during MIS 5.5 that was considerably warmer than at present. Whether this warming was sufficient for thermal expansion effects on sea level is beyond the scope of this paper, but the observations made here indicate that further work on this topic is merited. 
Implications for Late Quaternary Glacial Isostatic Adjustment Models of Sea Level History

The elevation and age data reported here have implications for models of the effects of GIA processes on the sea level record of coastal southern California. In this discussion, consideration is made not only of SBI and ANA, but also the Fraser Point area of western Santa Cruz Island. Worldwide the peak of the LIG period at $\sim 120 \mathrm{ka}$ (MIS 5.5) is considered to have had a eustatic sea level somewhere between $\sim 3 \mathrm{~m}$ and $\sim 10 \mathrm{~m}$ above present, with a value of $6 \pm 3 \mathrm{~m}$ commonly quoted (see review in Murray-Wallace and Woodroffe 2014). These values were obtained from tectonically stable locations, distant from plate boundaries, that serve as "high-water marks" for this major interglacial period. As discussed earlier, however, a complicating factor is the effect that GIA processes can have on such estimates. For regions close to continents that hosted major ice sheets, there are departures from solely eustatic sea levels, as shown for the $\sim 80$-ka and $\sim 100$-ka high-sea stands. It is pertinent, then, to investigate whether geologic records on the California coast are consistent with modeling of the $\sim 120$-ka high-sea stand. In a recent study by Creveling et al. (2015), sea level at $\sim 127 \mathrm{ka}$ to $\sim 120 \mathrm{ka}$ is estimated to have been as high as $\sim 11 \mathrm{~m}$ above present (assuming a purely eustatic sea level of $+6 \mathrm{~m}$ ) to $\sim 13 \mathrm{~m}$ above present (assuming a purely eustatic sea level of $+8 \mathrm{~m}$ ) on the southern California coast. These values are in good agreement with those of another modeling study where LIG $(\sim 120 \mathrm{ka})$ paleo-sea level estimates of $+12 \mathrm{~m}$ to $+13 \mathrm{~m}$ relative to present were reported for much of the Pacific Coast of North America, from northern California to northern Baja California (Simms et al. 2016).

The GIA estimates of paleo-sea level presented by Creveling et al. (2015) and Simms et al. (2016) can be assessed from the geologic records of the LIG period for SBI, ANA, and Santa Cruz Island presented here. Based on the amino acid data discussed previously, we assume that the initial formation of the lowelevation terraces on all three islands dates to the peak of the LIG period (MIS 5.5) at 120 ka. The next-highest terraces on all three islands are at considerably higher elevations than the lowest terraces (Figs. 2, 3, 5, 6). Furthermore, at least on both Santa Barbara Island and Anacapa Island, the higher terraces contain the extinct gastropod Calicantharus fortis, which is absent on the lower terraces. From this it can be inferred that all higher terraces on both islands are older than $\sim 120 \mathrm{ka}$. On both SBI and West Anacapa Island, the shoreline angle of the lowest terrace lies at an elevation of $\sim 11 \mathrm{~m}$. If the paleo-sea level estimates of $+11 \mathrm{~m}$ in the GIA models cited above are correct, then there would have been no uplift at all on these islands in the past $\sim 120,000$ years. If the paleo-sea level estimates of +12 to $+13 \mathrm{~m}$ are considered, then both islands would have to have subsided a meter or two in the past $\sim 120,000$ years. On western Santa Cruz Island, the shoreline angle elevations of the $\mathrm{T} 1$ terrace in the Fraser Point area are $\sim 7 \mathrm{~m}$ to $\sim 8 \mathrm{~m}$, as measured both in the present study and by Pinter et al. (2003). Based on the amino acid data presented here, fossils in the terrace deposits on this part of the island indicate correlation with the $\sim 120$-ka high-sea stand. The shoreline angle elevations at Fraser Point combined with the modeled GIA estimates of paleo-sea level at $\sim 120$ ka would require $\sim 3$ to $\sim 6 \mathrm{~m}$ of subsidence since the LIG high-sea stand.

The geomorphology of all three islands does not support the concept that these crustal blocks have subsided in the past $\sim 120 \mathrm{ka}$. The presence of higher marine terraces on all three islands indicates that the long-term tectonic history has been one of uplift, not subsidence. Indeed, uplift has probably been in progress on the islands since the Miocene, because Miocene marine sedimentary rocks (on Santa Cruz Island and ANA) and Miocene pillow lavas (on SBI) are well above modern sea level on these crustal blocks. Moreover, no credible structural evidence exists for a mechanism of subsidence, such as the islands being situated on the downthrown sides of normal faults. Therefore, it is inferred that the longterm tectonic character of these three islands has been one of uplift.

Another possibility is that the 11-m-high terraces on both SBI and ANA contain fossils from both the $\sim 120$-ka and 100-ka high-sea stands but that the shoreline angle elevations at $11 \mathrm{~m}$ reflect only the sea level position at $\sim 100$ ka. In this hypothetical scenario, fossils that are $\sim 120$ ka were reworked by sea-cliff retreat (rather than simple terrace reoccupation) 
during the $~ 100-k a$ high-sea stand from a slightly higher terrace that formed during the $\sim 120$-ka high-sea stand but that was completely eroded away. If we assume the local paleo-sea level from San Nicolas Island at $\sim 100 \mathrm{ka}$, which is estimated to have been $+4 \mathrm{~m}$ $( \pm 2 \mathrm{~m})$ relative to present (Muhs et al. 2012), the shoreline angle elevations at $11 \mathrm{~m}$ on SBI and ANA would imply a tectonic uplift rate of $0.07 \mathrm{~m} / \mathrm{ka}$ since the $\sim 100$-ka high-sea stand. At that rate, the amount of uplift in $\sim 120 \mathrm{ka}$ would be $\sim 8.4 \mathrm{~m}$. If the GIA-modeled estimates of a paleo-sea level of +11 to $+13 \mathrm{~m}$ at $\sim 120 \mathrm{ka}$ are correct, we should expect to see terraces on both SBI and ANA with shoreline angle elevations of $\sim 19 \mathrm{~m}$ to $\sim 21 \mathrm{~m}$ above present sea level. On western Santa Cruz Island we should see a terrace with a shoreline angle elevation of $\sim 16 \mathrm{~m}$ to $\sim 18 \mathrm{~m}$. No terraces at these elevations were observed in the present study. It is possible that such terraces could have existed prior to the $\sim 100$-ka high-sea stand and were eroded away completely by sea-cliff retreat during the $\sim 100$-ka high-sea stand on all 3 islands. While this scenario remains a possibility, a simpler explanation is terrace reoccupation at $\sim 100 \mathrm{ka}$, accompanied by mixing fossils of $\sim 100 \mathrm{ka}$ and $\sim 120 \mathrm{ka}$ age.

Another method of testing GIA modeling for the LIG is to examine the record from a tectonically stable location within the region. Although locations that should be tectonically stable, based on first principles of plate settings, are rare on the Pacific Coast of North America, one such locality does exist and has marine terrace data that allow such a test. Isla Guadalupe, off the coast of Baja California, (Figs. 1a, 16a) is distant from any plate boundary, has no active faults nearby, has no active volcanoes on or near it, is bounded on its eastern side by a seafloor with undisturbed marine sediment, and has no history of recent strong earthquakes (Gonzalez-Garcia et al. 2003). Marine deposits on Isla Guadalupe contain corals with U-series ages of $\sim 120 \mathrm{ka}$ (Muhs et al. 2002a). Lindberg et al. (1980) report that emergent marine deposits on Isla Guadalupe have elevations ranging from $1 \mathrm{~m}$ to $8 \mathrm{~m}$ above sea level, with most localities described as 1-6 $\mathrm{m}$ above sea level. If sea level were truly +11 to $+13 \mathrm{~m}$ above present during the LIG period (as the models of Creveling et al. 2015 and Simms et al. 2016 indicate for this island as well), Isla Guadalupe would have to have experienced significant subsidence in the past $\sim 120 \mathrm{ka}$. Given its geologic setting, there is simply no apparent mechanism that would have brought about late Quaternary subsidence. Considering all of the evidence presented here, the simplest explanation is that the modeled GIA estimates of paleo-sea level for the peak of the LIG period are too high.

\section{Conclusions}

Studies of marine terraces on the two smallest islands within Channel Islands National Park lead to a number of conclusions. The lowest-elevation terraces on SBI and ANA have shoreline angle elevations at $\sim 11 \mathrm{~m}$ above sea level. Fossil mollusks on these terraces have amino acid $\mathrm{D} / \mathrm{L}$ values that allow correlation to the peak of the LIG period (MIS 5.5), $\sim 120 \mathrm{ka}$. In addition, however, terrace deposits of both islands also contain fossils with significantly lower $\mathrm{D} / \mathrm{L}$ values, indicating a younger age; these values fall within an aminozone of marine terrace fossils from southern California that have been independently dated to $\sim 80 \mathrm{ka}$ (MIS 5.1). When temperature history and sea level history are taken into consideration, we conclude that it is more likely that the younger fossils date to the -100-ka high-sea stand (MIS 5.3). If this interpretation is correct, it is consistent with observations of other terrace localities in California where mixes of $\sim 120$-ka and $\sim 100-\mathrm{ka}$ fossils have been reported. Glacial isostatic adjustment processes and their effects on relative sea levels are invoked to explain this fossil mixing through terrace reoccupation.

Fossil mollusks are abundant within the marine terrace deposits on SBI and, to a lesser degree, ANA and indicate a rocky intertidal environment at the time the organisms were alive, similar to the modern rocky-shore environments of these islands. However, the molluscan faunas, particularly on SBI, contain both extralimital southern and northern species, as well as southward-ranging and northwardranging species. Based on comparisons to other marine terrace localities in southern California with independent ages $(\sim 120 \mathrm{ka}$ and $\sim 100 \mathrm{ka}$ ) and similar mixes of faunas with contrasting thermal aspects, the warm-water forms are interpreted to correlate with the -120-ka high-sea stand and the cool-water forms are interpreted to correlate with the 
$\sim 100$-ka high-sea stand. This interpretation is consistent with planktonic foraminiferal data from Santa Barbara Basin. Thus, the paleozoogeographic aspects of the terrace faunas are also consistent with the amino acid data, which indicate that the marine terraces on these islands are composite features, formed from two high-sea stands. Such a mechanism is possible because, according to GIA models, the sea level at $\sim 100$ ka was likely above present and this high-sea stand "captured" the marine terrace that formed at $\sim 120 \mathrm{ka}$.

Other data presented here disagree with some GIA modeling of sea level during the earlier 120-ka high-sea stand. Recent GIA modeling studies that indicate that the peak LIG sea level at $120 \mathrm{ka}$ was 11-13 m above present are not consistent with shoreline angle elevations of $\sim 11 \mathrm{~m}$ (at SBI and ANA) and $\sim 7-8 \mathrm{~m}$ (at the western part of Santa Cruz Island). If sea level at $\sim 120 \mathrm{ka}$ was really as high as $13 \mathrm{~m}$ above present sea level, then all three islands would have to have experienced subsidence. There is no geomorphic or structural evidence to support this, and we conclude that the modeled paleo-sea levels at $\sim 120 \mathrm{ka}$ are likely too high. The present study demonstrates that sea level modeling must be tested with field evidence, such as the marine terrace data presented here for the Channel Islands.

\section{ACKNOWLEDGMENTS}

We dedicate this paper to the late James H. McLean, former curator of the Malacology Department of the Natural History Museum of Los Angeles County. Jim was one of the most respected malacologists in the world and certainly was the world's expert on eastern Pacific gastropods. His legacy at the museum will live on through the incredible collections that he made so carefully over many decades. Numerous people helped with this study and it is our pleasure to thank them. Channel Islands National Park, particularly Kate Faulkner (National Park Service [NPS], retired), gave us collecting permits and provided essential logistical support throughout the course of the study, including transportation and accommodations. Kate was a constant source of encouragement for this study. We thank Dan Richards (also NPS, retired), who helped us collect fossils on Santa Barbara Island. Laurie Harvey (formerly of the NPS) and Island Packers Cruises helped us reach difficult parts of Middle Anacapa and West Anacapa Islands, which we appreciate. Randy Schumann helped with fieldwork on both Santa Barbara Island and Anacapa Island, for which we express our sincere thanks. Our thanks also go to The Nature Conservancy, who allowed us access to the Fraser Point area of Santa Cruz Island. The University of California, Santa Barbara (Lyndal Laughrin, Reserve Director), kindly provided accommodations on Santa Cruz Island at the university's field station. Austin Hendy, Collections Manager of the Invertebrate Paleontology Section at the Natural History Museum of Los Angeles County, kindly allowed us to analyze material from collections at the museum, for which we extend our sincere thanks. Thanks go to Nicholas Lancaster (Desert Research Institute, retired) who collected the shells at Puerto Peñasco and kindly allowed us to present the results here. We thank George L. Kennedy who collected the mollusks at LACMIP loc. 12576 in San Pedro that were examined in this study. We also extend our thanks to Janice Lipeles (volunteer at the Natural History Museum of Los Angeles, Section of Malacology) who picked the sediment samples for microspecimens. Amino acid analyses were ably conducted by Stephen DeVogel in the Amino Acid Geochronology Laboratory at the University of Colorado, supervised by Dr. Gifford H. Miller. Markes Johnson (Williams College), John F. Wehmiller (University of Delaware), Jeff Pigati (U.S. Geological Survey), Randy Schumann (U.S. Geological Survey), Janet Slate (U.S. Geological Survey), and an anonymous reviewer provided helpful comments that improved an earlier version of this manuscript; we thank them for their efforts. The study was supported by the U.S. Geological Survey's Climate and Land Use Change Program and is a contribution to the Geologic Records of High Sea Levels project. Any use of trade, product, or firm names is for descriptive purposes only and does not imply endorsement by the U.S. Government.

\section{Literature Cited}

Aвbott, D.F., And E.C. Haderlie. 1980. Prosobranchia: marine snails. Pages 230-307 in R.H. Morris, D.P. Abbott, and E.C. Haderlie, editors, Intertidal invertebrates of California. Stanford University Press, Stanford, CA. 
Аввотт, R.T. 1974. American seashells: the marine Mollusca of the Atlantic and Pacific Coasts of North America. 2nd edition. Van Nostrand Reinhold Company, New York, NY.

AshbY, J.R., T.L. KU, AND J.A. Minch. 1987. Uranium-series ages of corals from the upper Pleistocene Mulege terrace, Baja California Sur, Mexico. Geology 15:139-141.

Bartsch, P. 1915. The recent and fossil mollusks of the genus Rissoina from the west coast of America. Proceedings of the National Museum 49:33-62.

Bertsch, H., and L.E. Aguilar Rosas. 2016. Invertebratos marinos del noroeste de México [Marine invertebrates of northwest Mexico]. Instituto de Investigaciones Oceanológicas, Universidad Autónoma de Baja California, Ensenada, B.C., Mexico.

Bloom, A.L., W.S. Broecker, J.M.A. Chappell, R.K. Matthews, and K.J. Mesolella. 1974. Quaternary sea level fluctuations on a tectonic coast: New ${ }^{230} \mathrm{Th} /{ }^{234} \mathrm{U}$ dates from the Huon Peninsula, New Guinea. Quaternary Research 4:185-205.

Bock, Y., J. Bear, P. Fang, J. Dean, and R. Leigh. 1997. Scripps Orbit and Permanent Array Center (SOPAC) and Southern Californian Permanent GPS Geodetic Array (PGGA). Pages 55-61 in The Global Positioning System for Geosciences, National Academy Press, Washington, DC.

Brigham-Grette, J., and D.M. Hopkins. 1995. Emergent marine record and paleoclimate of the last interglaciation along the northwest Alaskan coast. Quaternary Research 43:159-173.

Broecker, W.S., D.L. Thurber, J. Goddard, T.-L. Ku, R.K. Matthews, and K.J. Mesolella. 1968. Milankovitch hypothesis supported by precise dating of coral reefs and deep-sea sediments. Science 159: 297-300.

Chace, E.P. 1958. The marine molluscan fauna of Guadalupe Island, Mexico. Transactions of the San Diego Society of Natural History 12:319-332.

Chappell, J., A. Omura, T. Esat, M. McCulloch, J. Pandolfi, Y. Ota, and B. Pillans. 1996. Reconciliation of late Quaternary sea levels derived from coral terraces at Huon Peninsula with deep sea oxygen isotope records. Earth and Planetary Science Letters 141:227-236.

Cheng, H., R.L. Edwards, C.-C. Shen, V.J. Polyak, Y. Asmerom, J. Woodhead, J. Hellstrom, Y. Wang, X. Kong, C. SPOTL, ET AL. 2013. Improvements in ${ }^{230} \mathrm{Th}$ dating, ${ }^{230} \mathrm{Th}$ and ${ }^{234} \mathrm{U}$ half-life values, and $\mathrm{U}-\mathrm{Th}$ isotopic measurements by multi-collector inductively coupled plasma mass spectrometry. Earth and Planetary Science Letters 371-372:82-91.

Church, J.A., P.U. Clark, A. Cazenave, J.M. Gregory, S. Jevrejeva, A. Levermann, M.A. Merrifield, G.A. Milne, R.S. Nerem, P.D. Nunn, ET AL. 2013. Sea level change. Pages 1137-1216 in T.F. Stocker, D. Qin, G.-K. Plattner, M. Tignor, S.K. Allen, J. Boschung, A. Nauels, Y. Xia, V. Bex, and P.M. Midgley, editors, Climate change 2013: the physical science basis. Contribution of Working Group I to the Fifth Assessment Report of the Intergovernmental Panel on Climate Change. Cambridge University Press, Cambridge, United Kingdom, and New York, NY, USA.

Clark, J., J.X. Mitrovica, and J. Alder. 2014. Coastal paleogeography of the California-Oregon-Washington and Bering Sea continental shelves during the latest Pleistocene and Holocene: implications for the archaeological record. Journal of Archaeological Science 52:12-23.

Coan, E.V., AND P. Valentich-Scott. 2012. Bivalve seashells of tropical west America. Santa Barbara Museum of Natural History, Santa Barbara, CA.

Coan, E.V., P. Valentich-Scott, and F.R. Bernard. 2000. Bivalve seashells of western North America: marine bivalve mollusks from Arctic Alaska to Baja California. Santa Barbara Museum of Natural History, Santa Barbara, CA.

Creveling, J.R., J.X. Mitrovica, C.C. Hay, J. AusterMANN, AND R.E. KOPP. 2015. Revisiting tectonic corrections applied to Pleistocene sea-level highstands. Quaternary Science Reviews 111:72-80.

Creveling, J.R., J.X. Mitrovica, P.U. Clark, C. WaelBRoECK, AND T. PICO. 2017. Predicted bounds on peak global mean sea level during marine isotope stages 5a and 5c. Quaternary Science Reviews 163:193-208.

Cutler, K.B., R.L. Edwards, F.W. Taylor, H. Cheng, A. Adkins, C.D. Gallup, P.M. Cutler, G.S. BurR, and A.L. BLoom. 2003. Rapid sea-level fall and deep ocean temperature change since the last interglacial period. Earth and Planetary Science Letters 206: 253-271.

Davis, O.K., A.H. Cutler, K.H. Meldahl, M.R. PalaciosFest, J.F. Schreiber JR., B.E. Lock, N. LanCaster, C.A. Shaw, And S.M. Sinitiere. 1990. Quaternary geology of Bahia Adair and the Gran Desierto region. In: Deserts, Evolution Passeé et Future [Past and Future Evolution], IGCP 252 Publication. $32 \mathrm{pp}$.

Dibblee, T.W., JR. 2001. Geologic map of Anacapa and Santa Barbara Islands, Channel Islands National Park, Ventura and Santa Barbara Counties, California: Santa Barbara, California, Dibblee Geological Foundation Map DF-73, scale 1:24,000.

Dodge, R.E., R.G. Fairbanks, L.K. Benninger, and F. Maurrasse. 1983. Pleistocene sea levels from raised coral reefs of Haiti. Science 219:1423-1425.

Dutton, A., And K. LAmbeck. 2012. Ice volume and sea level during the last interglacial. Science 337: 216-219.

Dutton, A., J.M. Webster, D. Zwartz, K. Lambeck, and B. Wohlfarth. 2015. Tropical tales of polar ice: evidence of Last Interglacial polar ice sheet retreat recorded by fossil reefs of the granitic Seychelles Islands. Quaternary Science Reviews 107:182-196.

Edwards, R.L., H. Cheng, M.T. Murrell, and S.J. Goldstern. 1997. Protactinium-231 dating of carbonates by thermal ionization mass spectrometry: implications for Quaternary climate change. Science 276:782-786.

Eernisse, D.J., R.N. Clark, and A. Draeger. 2007. Polyplacophora. Pages 701-713 in J.T. Carlton, editor, The Light and Smith manual: intertidal invertebrates from central California to Oregon. 4th edition. University of California Press, Berkeley, CA.

EMERSON, W.K. 1980. Invertebrate faunules of late Pleistocene age, with zoogeographic implications, from Turtle Bay, Baja California Sur, Mexico. Nautilus 94:67-89.

Emerson, W.K., G.L. Kennedy, J.F. Wehmiller, And E. KeEnan. 1981. Age relations and zoogeographic implications of late Pleistocene marine invertebrate faunas from Turtle Bay, Baja California Sur, Mexico. Nautilus 95:105-116. 
Fenberg, P.B., K. Posbic, and M.E. Hellberg. 2014. Historical and recent processes shaping the geographic range of a rocky intertidal gastropod: phylogeography, ecology, and habitat availability. Ecology and Evolution 4:3244-3255.

Gallup, C.D., R.L. Edwards, and R.G. Johnson. 1994. The timing of high sea levels over the past 200,000 years. Science 263:796-800.

Gonzalez-Garcia, J.J., L. Prawirodirdjo, Y. Bock, and D. Agnew. 2003. Guadalupe Island, Mexico as a new constraint for Pacific Plate motion. Geophysical Research Letters 30(16):1872.

Grant, L.B., K.J. Mueller, E.M. Gath, H. Cheng, R.L. Edwards, R. Munro, and G.L. Kennedy. 1999. Late Quaternary uplift and earthquake potential of the San Joaquin Hills, southern Los Angeles Basin, California. Geology 27:1031-1034.

Grove, K., K. Colson, M. Binkin, R. Dull, and C. GARRISON. 1995. Stratigraphy and structure of the late Pleistocene Olema Creek Formation, San Andreas fault zone north of San Francisco, California. Pages 55-76 in E.M. Sanginés, D.W. Andersen, and A.V. Buising, editors, Recent geologic studies in the San Francisco Bay Area. Pacific Section of the Society of Economic Paleontologists and Mineralogists 76 .

Groves, L.T. 1991a. Paleontology and biostratigraphy of the Plio-Pleistocene lower Saugus Formation, Santa Susana Mountains, southern California. Master's thesis, California State University, Northridge, CA. xiv $+383 \mathrm{pp}$.

Groves, L.T. 1991b. Molluscan paleontology of the Pliocene-Pleistocene lower Saugus Formation, southern California. American Conchologist 19:16-17.

Haderlie, E.C., AND D.P. AвbotT. 1980. Polyplacophora: the chitons. Pages 412-428 in R.H. Morris, D.P. Abbott, and E.C. Haderlie, editors, Intertidal invertebrates of California. Stanford University Press, Stanford, CA.

Hendy, I.L. 2010. The paleoclimatic response of the southern Californian margin to the rapid climate change of the last $60 \mathrm{ka}$ : a regional overview. Quaternary International 215:62-73.

Hertz, J. 1995. Acanthina lugubris found again in San Diego. Festivus 27:110.

Heusser, L.E. 2000. Rapid oscillations in western North America vegetation and climate during oxygen isotope stage 5 inferred from pollen data from Santa Barbara Basin (Hole 893A). Palaeogeography, Palaeoclimatology, Palaeoecology 161:407-421.

Johnson, D.L. 1979. Geology, soils, and erosion. Pages 3.1-3.73 in D.M. Power, editor, Natural resources study, Channel Islands National Monument, California. Santa Barbara Museum of Natural History, Santa Barbara, CA.

Johnson, M.E., R.A. Lopez-Perez, C.R. Ransom, And J. Ledesma-VazQuez. 2007. Late Pleistocene coralreef development on Isla Coronados, Gulf of California. Ciencias Marinas 33:105-120.

Johnson, M.E., D.H. Backus, And J. Ledesma-VazQuez. 2017. Growth of the Ballena fan delta on the Gulf of California (Mexico) at the close of the Pliocene Warm Period. Facies 63:14.

Johnson, R.G. 1962. Mode of formation of marine fossil assemblages of the Pleistocene Millerton Formation of California. Geological Society of America Bulletin 73:113-130.
Jordan, E.K. 1936. The Pleistocene fauna of Magdalena Bay, Lower California. Contributions from the Department of Geology of Stanford University 1(4):103-174 [plates 17-19].

Kanakoff, G.P., And W.K. Emerson. 1959. Late Pleistocene invertebrates of the Newport Bay area, California. Natural History Museum of Los Angeles County Contributions in Science 31:1-47.

Kaufman, D.S., and W.F. Manley. 1998. A new procedure for determining DL amino acid ratios in fossils using reverse phase liquid chromatography. Quaternary Science Reviews 17:987-1000.

KeEn, A.M. 1971. Sea shells of tropical west America. Marine mollusks from Baja California to Peru. 2nd edition. Stanford University Press, Stanford, CA.

Kendrick, G.W., K.-H. Wyrwoll, and B.J. SZabo. 1991. Pliocene-Pleistocene coastal events and history along the western margin of Australia. Quaternary Science Reviews 10:419-439.

Kennedy, G.L. 2000. Zoogeographic correlation of marine invertebrate faunas. Pages 413-424 in J.S. Noller, J.M. Sowers, and W.R. Lettis, editors, Quaternary geochronology. American Geophysical Union Reference Shelf 4, Washington, DC.

Kennedy, G.L., K.R. Lajoie, and J.F. Wehmiller. 1982. Aminostratigraphy and faunal correlations of late Quaternary marine terraces, Pacific Coast, USA. Nature 299:545-547.

Kennedy, G.L., J.F. Wehmiller, and T.K. Rockwell. 1992. Paleoecology and paleozoogeography of late Pleistocene marine-terrace faunas of southwestern Santa Barbara County, California. Pages 343-361 in C.H. Fletcher III and J.F. Wehmiller, editors, Quaternary coasts of the United States: marine and lacustrine systems. SEPM [Society for Sedimentary Geology] Special Publication No. 48.

KennetT, J.P. 1995. Latest Quaternary benthic oxygen and carbon isotope stratigraphy: hole 893A, Santa Barbara Basin, California. Pages 3-18 in J.P. Kennett, J.G. Baldauf, and M. Lyles, editors, Proceedings of the Ocean Drilling Program, Scientific Results. Volume 146 (Part 2). National Science Foundation.

KennetT, J.P., AND K. Venz. 1995. Late Quaternary climatically related planktonic foraminiferal assemblage changes: hole 893A, Santa Barbara Basin, California. Pages 281-293 in J.P. Kennett, J.G. Baldauf, and M. Lyles, editors, Proceedings of the Ocean Drilling Program, Scientific Results. Volume 146 (Part 2). National Science Foundation.

Kern, J.P. 1977. Origin and history of upper Pleistocene marine terraces, San Diego, California. Geological Society of America Bulletin 88:1553-1566.

KosniK, M.A., AND D.S. Kaufman. 2008. Identifying outliers and assessing the accuracy of amino acid racemization measurements for geochronology: II. Data screening. Quaternary Geochronology 3: 328-341.

Kosnik, M.A., D.S. Kaufman, And Q. Hua. 2008. Identifying outliers and assessing the accuracy of amino acid racemization measurements for geochronology: I. Age calibration curves. Quaternary Geochronology 3:308-327.

Kosuge, S. 1969. Fossil mollusks of Oahu, Hawaii Islands. Bulletin of the National Science Museum [Tokyo, Japan] 12:783-794.

KU, T.-L., AND J.P. KERN. 1974. Uranium-series age of the upper Pleistocene Nestor Terrace, San Diego, Cali- 
fornia. Geological Society of America Bulletin 85: 1713-1716.

Lindberg, D.R., B. Roth, M.G. KellogG, and C.L. HubBs. 1980. Invertebrate megafossils of Pleistocene (Sangamon interglacial) age from Isla de Guadalupe, Baja California, Mexico. Pages 41-62 in D.M. Power, editor, The California islands: proceedings of a multidisciplinary symposium. Santa Barbara Museum of Natural History, Santa Barbara, CA.

LipPs, J.H. 1964. Late Pleistocene history of West Anacapa Island, California. Geological Society of America Bulletin 75:1169-1176.

Lipps, J.H., J.W. Valentine, and E. Mitchell. 1968. Pleistocene paleoecology and biostratigraphy, Santa Barbara Island, California. Journal of Paleontology 42:291-307.

LitTler, M.M. 1980. Overview of the rocky intertidal systems of southern California. Pages 265-306 in D.M. Power, editor, The California islands: proceedings of a multidisciplinary symposium. Santa Barbara Museum of Natural History, Santa Barbara, CA.

Luyendyk, B.P., P.B. Gans, And M.J. Kamerling. 1998. ${ }^{40} \mathrm{Ar} /{ }^{39} \mathrm{Ar}$ geochronology of southern California Neogene volcanism. Pages 9-35 in P.W. Weigand, editor, Contributions to the geology of the Northern Channel Islands, southern California. American Association of Petroleum Geologists, Pacific Section, MP-45, Bakersfield, CA.

Marko, P.B., AND G.J. Vermeij. 1999. Molecular phylogenetics and the evolution of labral spines among eastern Pacific Ocenebrine gastropods. Molecular Phylogenetics and Evolution 13:275-288.

Martinson, D.G., N.G. Pisias, J.D. Hays, J. Imbrie, T.C. Moore Jr., AND N.J. ShacKLETON. 1987. Age dating and the orbital theory of the ice ages: development of a high-resolution 0 to 300,000-year chronostratigraphy. Quaternary Research 27:1-29.

Masson-Delmotte, V., M. Schulz, A. Abe-Ouchi, J. Beer, A. Ganopolski, J.F. González Rouco, E. Jansen, K. Lambeck, J. Luterbacher, T. Naish, et AL. 2013. Information from paleoclimate archives. Pages 383-464 in T.F. Stocker, D. Qin, G.-K. Plattner, M. Tignor, S.K. Allen, J. Boschung, A. Nauels, Y. Xia, V. Bex, and P.M. Midgley, editors, Climate change 2013: the physical science basis. Contribution of Working Group I to the Fifth Assessment Report of the Intergovernmental Panel on Climate Change. Cambridge University Press, Cambridge, United Kingdom, and New York, NY, USA.

McKay, N.P., J.T. Overpeck, and B.L. Otto-Bliesner. 2011. The role of ocean thermal expansion in Last Interglacial sea level rise. Geophysical Research Letters 38:L14605. https://doi.org/10.1029/2011GL 048280

MCLEAN, J.H. 1978. Marine shells of southern California. Natural History Museum of Los Angeles County Science Series, 24.

MCLEan, J.H. 2007. Gastropoda. Shelled gastropoda. Pages 713-753 in J.T. Carlton, editor, The Light and Smith manual: intertidal invertebrates from central California to Oregon. 4th edition. University of California Press, Berkeley, CA.

Meco, J., H. Guillou, J.C. Carracedo, A. Lomoschitz, A.J.G. Ramos, and J.J. Rodriguez Yanez. 2002. The maximum warmings of the Pleistocene world climate recorded in the Canary Islands. Palaeogeography, Palaeoclimatology, Palaeoecology 185:197-210.
Mesolella, K.J., R.K. Matthews, W.S. Broecker, And D.L. Thurber. 1969. The astronomical theory of climatic change: Barbados data. Journal of Geology 77:250-274.

Miller, G.H. 1985. Aminostratigraphy of Baffin Island shell-bearing deposits. Pages 394-427 in J.T. Andrews, editor, Quaternary environments: Eastern Canadian Arctic, Baffin Bay, and West Greenland. George Allen \& Unwin, London.

Miller, G.H., D.S. Kaufman, and S.J. Clarke. 2013 Amino acid dating. Pages $37-48$ in S.A. Elias and C.J. Mock, editors, The encyclopedia of Quaternary sciences. 2nd edition. Elsevier, Amsterdam.

Miller, L., E.D. Mitchell, AND J.H. Lipps. 1961. New light on the flightless goose Chendytes lawi. Los Angeles County Museum Contributions in Science 43:1-11.

Milne, G.A., And J.X. Mitrovica. 2008. Searching for eustasy in deglacial sea-level histories. Quaternary Science Reviews 27:2292-2302.

Mitrovica, J.X., And G.A. MiLne. 2002. On the origin of late Holocene sea-level highstands within equatorial ocean basins. Quaternary Science Reviews 21: 2179-2190.

Mitrovica, J.X., And W.R. Peltier. 1991. On postglacial geoid subsidence over the equatorial oceans. Journal of Geophysical Research 96:20053-20071.

Muns, D.R. 1983. Quaternary sea-level events on northern San Clemente Island, California. Quaternary Research 20:322-341.

Muns, D.R. 1985. Amino acid age estimates of marine terraces and sea levels, San Nicolas Island, California. Geology 13:58-61.

Muns, D.R. 2002. Evidence for the timing and duration of the last interglacial period from high-precision uranium-series ages of corals on tectonically stable coastlines. Quaternary Research 58:36-40.

Muhs, D.R., G.H. Miller, J.F. Whelan, and G.L. KenNeDY. 1992. Aminostratigraphy and oxygen isotope stratigraphy of marine terrace deposits, Palos Verdes Hills and San Pedro areas, Los Angeles County, California. Pages 363-376 in C.H. Fletcher III and J.F. Wehmiller, editors, Quaternary coasts of the United States: marine and lacustrine systems. SEPM [Society for Sedimentary Geology] Special Publication No. 48.

Muhs, D.R., G.L. Kennedy, And T.K. Rockwell. 1994. Uranium-series ages of marine terrace corals from the Pacific Coast of North America and implications for last-interglacial sea level history. Quaternary Research 42:72-87.

Muns, D.R., K.R. Simmons, G.L. Kennedy, and T.K. ROCKWELL. 2002a. The last interglacial period on the Pacific Coast of North America: timing and paleoclimate. Geological Society of America Bulletin 114:569-592.

Muhs, D.R., K.R. Simmons, and B. Steinke. 2002 b. Timing and warmth of the last interglacial period: new U-series evidence from Hawaii and Bermuda and a new fossil compilation for North America. Quaternary Science Reviews 21:1355-1383.

Muhs, D.R., J.F. Wehmiller, K.R. Simmons, And L.L. YORK. 2004. Quaternary sea level history of the United States. Pages 147-183 in A.R. Gillespie, S.C. Porter, and B.F. Atwater, editors, The Quaternary Period in the United States. Amsterdam, Elsevier, Amsterdam. 
Muhs, D.R., J. Budahn, D.L. Johnson, M. Reheis, J. Beann, G. Skipp, E. Fisher, and J.A. Jones. 2008. Geochemical evidence for airborne dust additions to soils in Channel Islands National Park, California. Geological Society of America Bulletin 120:106-126.

Muhs, D.R., K.R. Simmons, G.L. Kennedy, K.R. Ludwig, AND L.T. Groves. 2006. A cool eastern Pacific Ocean at the close of the last interglacial complex. Quaternary Science Reviews 25:235-262.

Muhs, D.R., K.R. Simmons, R.R. Schumann, and R.B. HALLEY. 2011. Sea-level history of the past two interglacial periods: new evidence from U-series dating of reef corals from south Florida. Quaternary Science Reviews 30:570-590.

Muhs, D.R., K.R. Simmons, R.R. Schumann, L.T. Groves, J.X. Mitrovica, and D. Laurel. 2012. Sealevel history during the last interglacial complex on San Nicolas Island, California: implications for glacial isostatic adjustment processes, paleozoogeography and tectonics. Quaternary Science Reviews 37:1-25.

Muhs, D.R., K.R. Simmons, R.R. Schumann, L.T. Groves, S.B. Devogel, S.A. Minor, and D. LaUREL. 2014a. Coastal tectonics on the eastern margin of the Pacific Rim: late Quaternary sea-level history and uplift rates, Channel Islands National Park, California, USA. Quaternary Science Reviews 105: 209-238.

Muhs, D.R., L.T. Groves, and R.R. Schumann. 2014b. Interpreting the paleozoogeography and sea level history of thermally anomalous marine terrace faunas: a case study from the last interglacial complex of San Clemente Island, California. Monographs of the Western North American Naturalist 7:82-108.

Muns, D.R., J. Meco, And K.R. Simmons. 2014c. Uraniumseries ages of corals, sea level history, and palaeozoogeography, Canary Islands, Spain: an exploratory study for two Quaternary interglacial periods. Palaeogeography, Palaeoclimatology, Palaeoecology 394:99-118.

Muhs, D.R., K.R. Simmons, L.T. Groves, J.P. McGeehin, R.R. Schumann, And L.D. Agenbroad. 2015. Late Quaternary sea-level history and the antiquity of mammoths (Mammuthus exilis and Mammuthus columbi), Channel Islands National Park, California, USA. Quaternary Research 83:502-521.

Muhs, D.R., J.S. Pigati, R.R. Schumann, G.L. Skipp, N. Porat, and S.B. Devogel. 2018. Quaternary sealevel history and the origin of the northernmost coastal aeolianites in the Americas: Channel Islands National Park, California, USA. Palaeogeography, Palaeoclimatology, Palaeoecology 491:38-76.

Murray-Wallace, C.V., and C.D. Woodroffe. 2014. Quaternary sea-level changes: a global perspective. Cambridge University Press, Cambridge.

Murray-Wallace, C.V., A.G. Beu, G.W. Kendrick, L.J. Brown, A.P. Belperio, AND J.E. Sherwood. 2000. Palaeoclimatic implications of the occurrence of the arcoid bivalve Anadara trapezia (Deshayes) in the Quaternary of Australasia. Quaternary Science Reviews 19:559-590.

NorRis, R.W. 1991. A visit to Santa Barbara Island. California Geology 44:147-151.

NorRIs, R.W. 1995. Little Anacapa Island. California Geology 48:3-9.

o’Leary, M.J., P.J. Hearty, W.G. Thompson, M.E. Raymo, J.X. Mitrovica, and J.M. Webstre. 2013. Ice sheet collapse following a prolonged period of stable sea level during the last interglacial. Nature Geoscience 6:796-800.

Omura, A., W.K. Emerson, And T.L. Ku. 1979. Uraniumseries ages of echinoids and corals from the upper Pleistocene Magdalena terrace, Baja California Sur, Mexico. Nautilus 94:184-189.

OrtLieb, L. 1978. Reconocimiento de las terrazas marinas Cuaternarias en la parte central de Baja California. Univ. Nal. Autón. México, Inst. Geologia, Revista 2: 200-211.

Ortlieb, L. 1987. Néotectonique et variations du niveau marin au Quaternaire dans la région du Golfe de Californie, Méxique. Paris, Institut Français de Recherche Scientifique pour le Développement en Coopération, Collection Études et Théses. 1036 pp.

Pinter, N., S.B. Lueddecke, E.A. Keller, And K.R. Simmons. 1998. Late Quaternary slip on the Santa Cruz Island fault, California. Geological Society of America Bulletin 110:711-722.

Pinter, N., C.C. Sorlien, And A.T. Scott. 2003. Faultrelated growth and isostatic subsidence, California Channel Islands. American Journal of Science 303: 300-318.

Potter, E.-K., AND K. LAmbeck. 2003. Reconciliation of sea-level observations in the western North Atlantic during the last glacial cycle. Earth and Planetary Science Letters 217:171-181.

Radwin, G.E. 1974. Acanthina lugubris reappears in San Diego. Festivus 5:114.

Reeder-Myers, L., J.M. Erlandson, D.R. Muhs, and T.C. Rick. 2015. Sea level, paleogeography, and archeology on California's Northern Channel Islands. Quaternary Research 83:263-272.

Rockwell, T.K., D.R. Muhs, G.L. Kennedy, M.E. Hatch, S.H. Wilson, AND R.E. Klinger. 1989. Uraniumseries ages, faunal correlations and tectonic deformation of marine terraces within the Agua Blanca fault zone at Punta Banda, northern Baja California, Mexico. Pages 1-16 in P.L. Abbott, editor, Geologic studies in Baja California. Pacific Section, Society of Economic Paleontologists and Mineralogists, Los Angeles.

Roy, K., D. Jablonski, and J.W. Valentine. 1995. Thermally anomalous assemblages revisited: patterns in the extraprovincial latitudinal range shifts of Pleistocene marine mollusks. Geology 23:1071-1074.

SCHOLL, D.W. 1960. Relationship of the insular shelf sediments to the sedimentary environments and geology of Anacapa Island, California. Journal of Sedimentary Petrology 30:123-139.

Shackleton, N.J., AND N.D. OpdyKe. 1973. Oxygen isotope and palaeomagnetic stratigraphy of equatorial Pacific core V28-238: oxygen isotope temperatures and ice volumes on a $10^{5}$ year and $10^{6}$ year scale. Quaternary Research 3:39-55.

Simms, A.R., H. Rouby, AND K. Lambeck. 2016. Marine terraces and rates of vertical tectonic motion: the importance of glacio-isostatic adjustment along the Pacific coast of central North America. Geological Society of America Bulletin 128(1-2):81-93.

SquiRes, D.F. 1959. Results of the Puritan-American Museum of Natural History expedition to western Mexico. 7. Corals and coral reefs in the Gulf of California. Bulletin of the American Museum of Natural History 118:367-432.

Stein, M., G.J. Wasserburg, K.R. Lajoie, and J.H. Chen. 1991. U-series ages of solitary corals from the 
California coast by mass spectrometry. Geochimica et Cosmochimica Acta 55:3709-3722.

Steinbeck, J., And E.F. RicketTs. 1941. Sea of Cortez. Viking Press, New York, NY.

Strange, W., and N. Weston. 1997. National Geodetic Survey Continuously Operating Reference System (CORS). Pages 103-109 in The Global Positioning System for geosciences. National Academy Press, Washington, DC.

Tamisiea, M.E., And J.X. Mitrovica. 2011. The moving boundaries of sea level change: understanding the origins of geographic variability. Oceanography 24 : 24-39.

Thompson, W.G., H.A. Curran, M.A. Wilson, and B. White. 2011. Sea-level oscillations during the last interglacial highstand recorded by Bahamas corals. Nature Geoscience 4:684-687.

Turney, C.S.M., And R.T. Jones. 2010. Does the Agulhas Current amplify global temperatures during superinterglacials? Journal of Quaternary Science 25: 839-843.

Valentine, J.W. 1962. Pleistocene molluscan notes. 4. Older terrace faunas from Palos Verdes Hills, California. Journal of Geology 70:92-101.

VALENTINE, J.W. 1966. Numerical analysis of marine molluscan ranges on the extra-tropical northeastern Pacific shelf. Limnology and Oceanography 11:198-211.

Valentine, J.W. 1980. Camalú: a Pleistocene terrace fauna from Baja California. Journal of Paleontology 54:1310-1318.

Valentine, J.W., AND J.H. LipPs. 1963. Late Cenozoic rocky-shore assemblages from Anacapa Island, California. Journal of Paleontology 37:1292-1302.

Vedder, J.G., AND R.M. NorRIS. 1963. Geology of San Nicolas Island California. U.S. Geological Survey Professional Paper 369.

Wehmiller, J.F. 1982. A review of amino acid racemization studies in Quaternary mollusks: stratigraphic and chronologic applications in coastal and interglacial sites, Pacific and Atlantic Coasts, United States, United Kingdom, Baffin Island, and tropical islands. Quaternary Science Reviews 1:83-120.

Wehmiller, J.F. 1992. Aminostratigraphy of southern California Quaternary marine terraces. Pages 317-321 in C.H. Fletcher III and J.F. Wehmiller, editors, Quaternary coasts of the United States: marine and lacustrine systems, SEPM [Society for Sedimentary Geology] Special Publication No. 48.

Wehmiller, J.F. 2013a. United States Quaternary coastal sequences and molluscan racemization geochronology - what have they meant for each other over the past 45 years? Quaternary Geochronology 16:3-20.

Wehmiller, J.F. 2013b. Amino acid racemization, coastal sediments. Pages 1-10 in W.J. Rink and J. Thompson, editors, Encyclopedia of scientific dating methods. Springer-Verlag, Berlin Heidelberg.

WeHmiller, J.F. 2013c. Interlaboratory comparison of amino acid enantiomeric ratios in Pleistocene fossils. Quaternary Geochronology 16:173-182.
Wehmiller, J.F., and W.K. Emerson. 1980. Calibration of amino acid racemization in late Pleistocene mollusks: results from Magdalena Bay, Baja California Sur, Mexico, with dating applications and paleoclimatic implications. Nautilus 94:31-36.

Wehmiller, J.F., and G.H. Miller. 2000. Aminostratigraphic dating methods in Quaternary geology. Pages 187-222 in J.S. Noller, J.M. Sowers, and W.R. Lettis, editors, Quaternary geochronology, applications and methods. American Geophysical Union, Washington, DC.

Wehmiller, J.F., and V. Pellerito. 2015. Database of Quaternary coastal geochronologic information for the Atlantic and Pacific Coasts of North America (additional information for sites in Peru and Chile). Delaware Geological Survey Open File Report 50. 7 pp. http://www.dgs.udel.edu/publications/ofr50-data base-quaternary-coastal-geochronologic-inform

Wehmiller, J.F., K.R. Lajoie, K.A. Kvenvolden, E. Peterson, D.F. Belknap, G.L. Kennedy, W.O. AdDicotT, J.G. Vedder, AND R.W. Wright. 1977. Correlation and chronology of Pacific Coast marine terrace deposits of continental United States by fossil amino acid stereochemistry-technique evaluation, relative ages, kinetic model ages, and geologic implications. U.S. Geological Survey Open-File Report 77-680. 196 pp.

Wehmiller, J.F., K.R. Simmons, H. Cheng, R.L. EdWards, J. Martin-McNaughton, L.L. York, D.E. Krantz, And C.-C. Shen. 2004. Uranium-series coral ages from the U.S Atlantic Coastal Plain-the " 80 ka problem” revisited. Quaternary International 120:3-14.

Weigand, P.W., and K.L. Savage. 2002. Summary of the Miocene igneous rocks of the Channel Islands, southern California. Pages 106-114 in D.R. Browne, K.L. Mitchell, and H.W. Chaney, editors, Proceedings of the Fifth California Islands Symposium, Santa Barbara Museum of Natural History, Santa Barbara, CA.

Weigand, P.W., K.L. Savage, T. Reid, and B. Chinn. 1998. Composition of volcanic rocks on Santa Rosa, San Miguel, and Santa Barbara Islands, California. Pages 37-47 in P.W. Weigand, editor, Contributions to the geology of the Northern Channel Islands, southern California. American Association of Petroleum Geologists, Pacific Section, MP-45, Bakersfield, CA.

Woodring, W.P., M.N. Bramlette, and W.S.W. KeW. 1946. Geology and paleontology of Palos Verdes Hills, California. U.S. Geological Survey Professional Paper 207.

Received 7 March 2017

Revised 28 December 2017

Accepted 12 January 2018

Published online 31 December 2018 


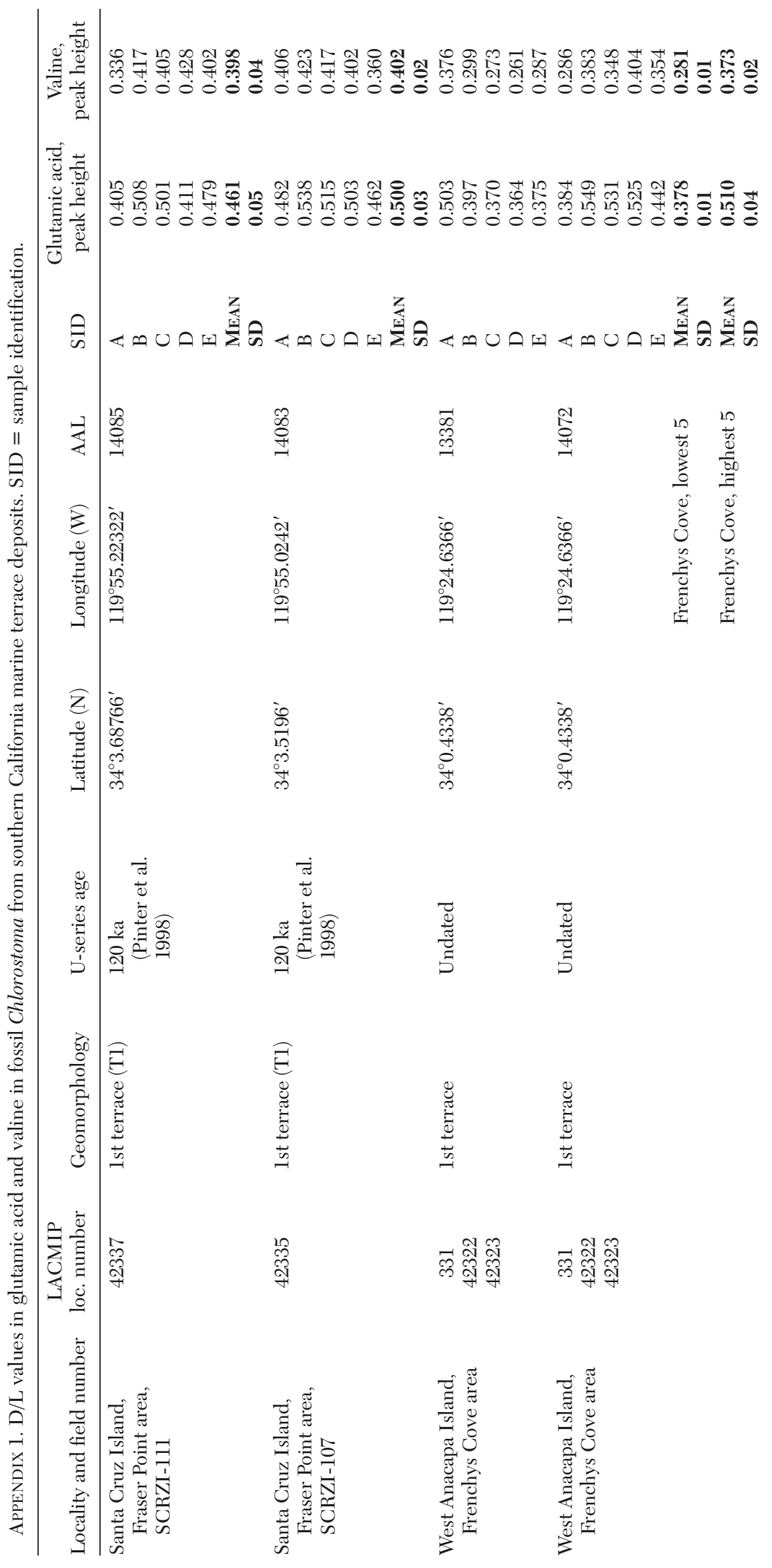




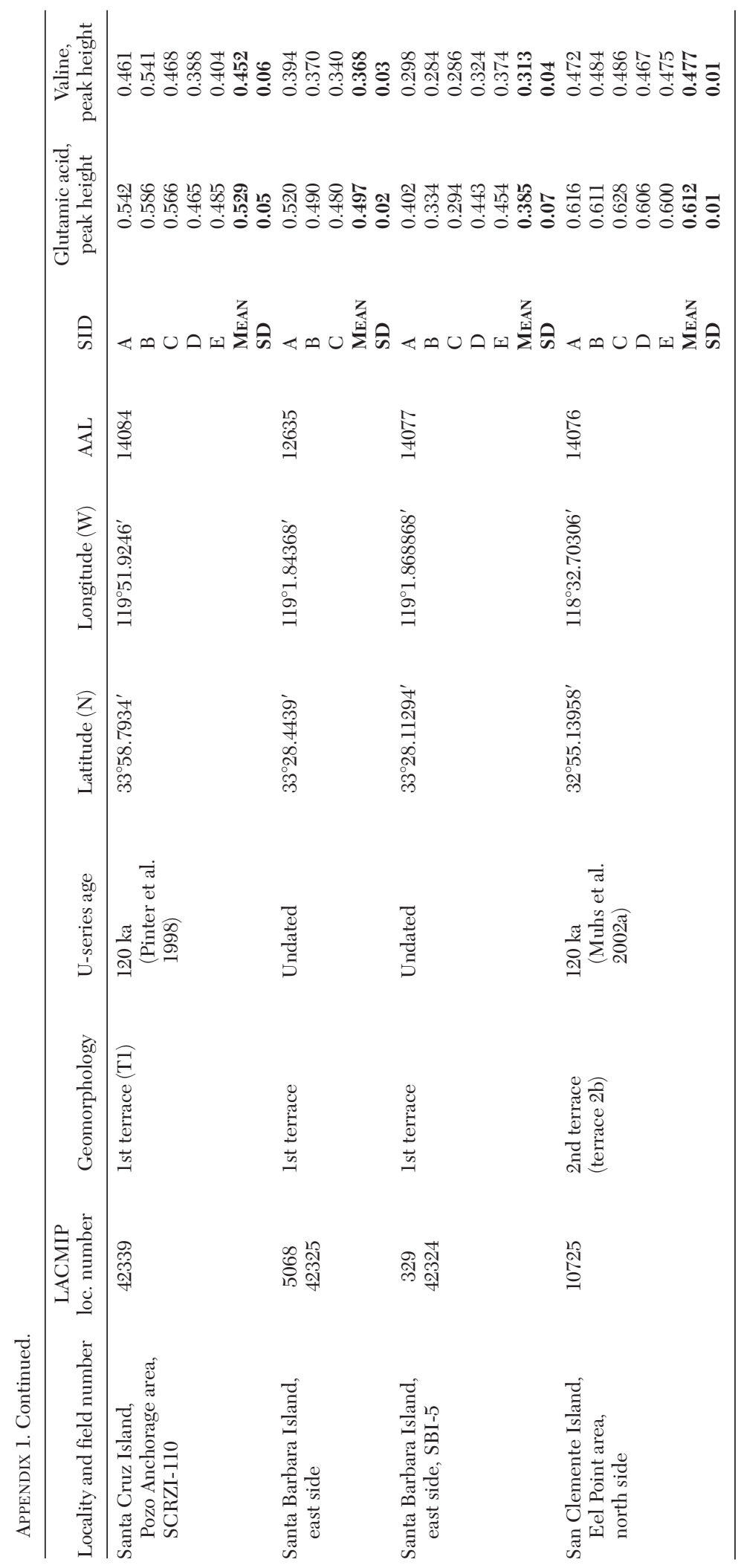




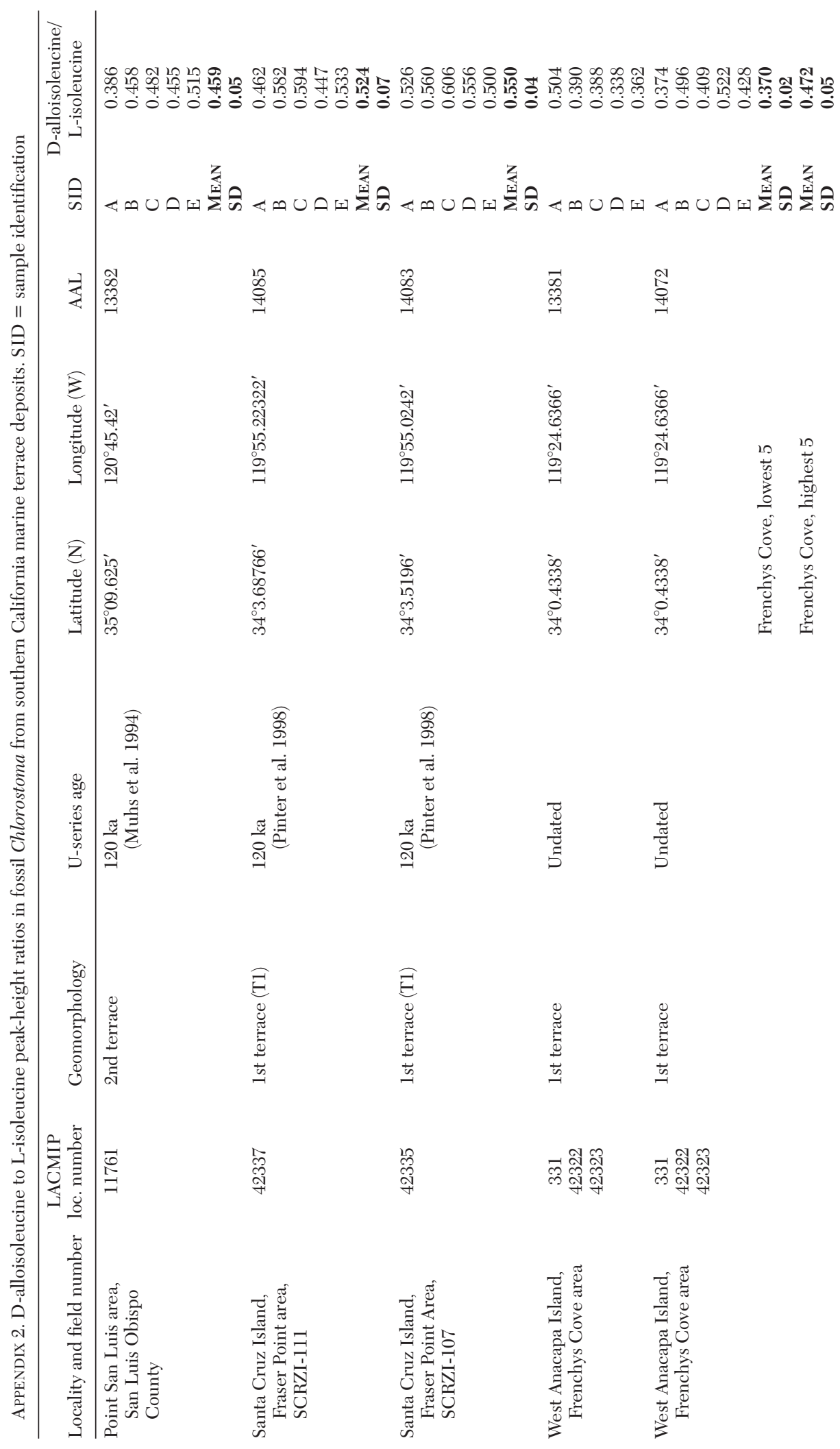




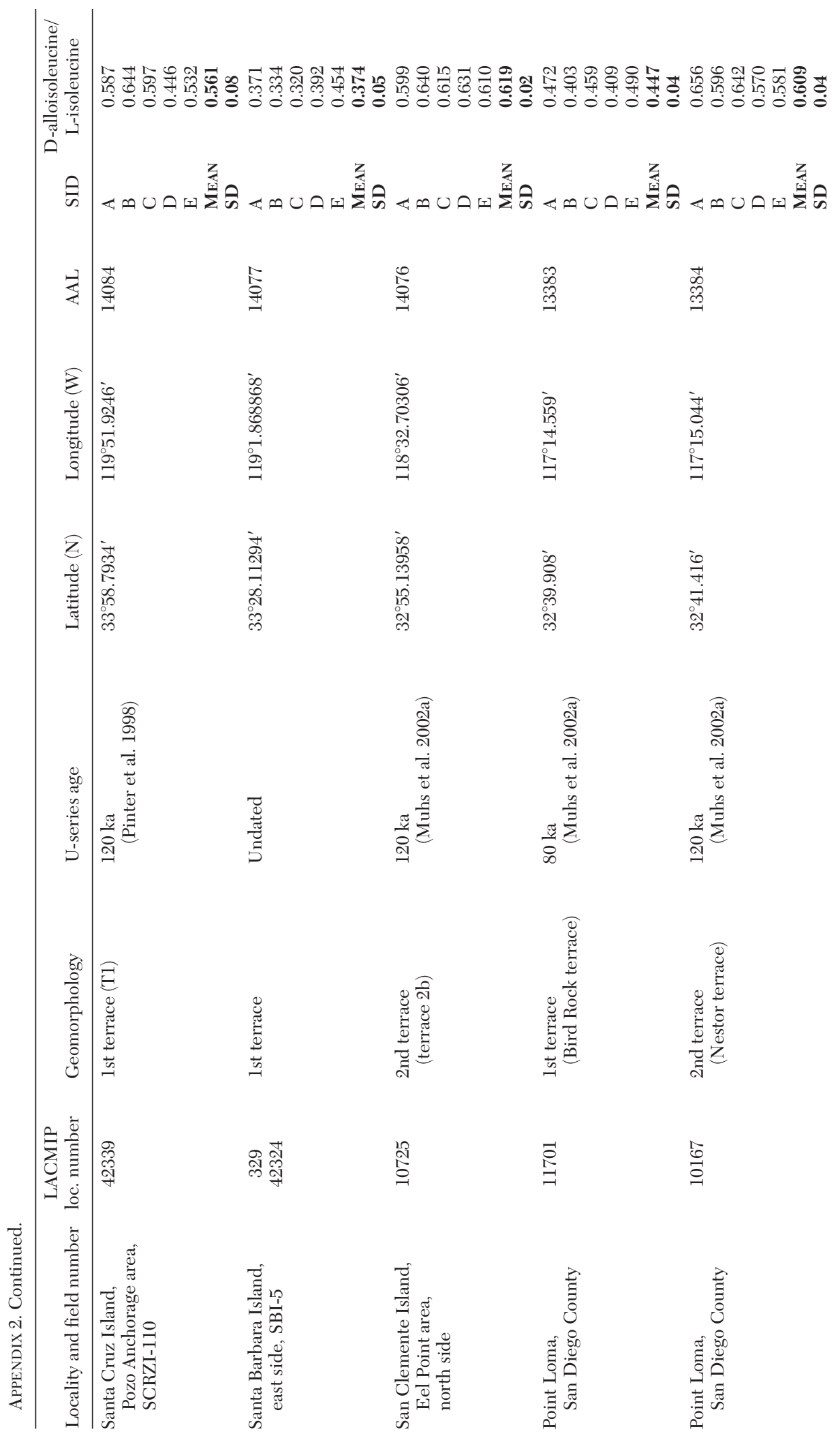




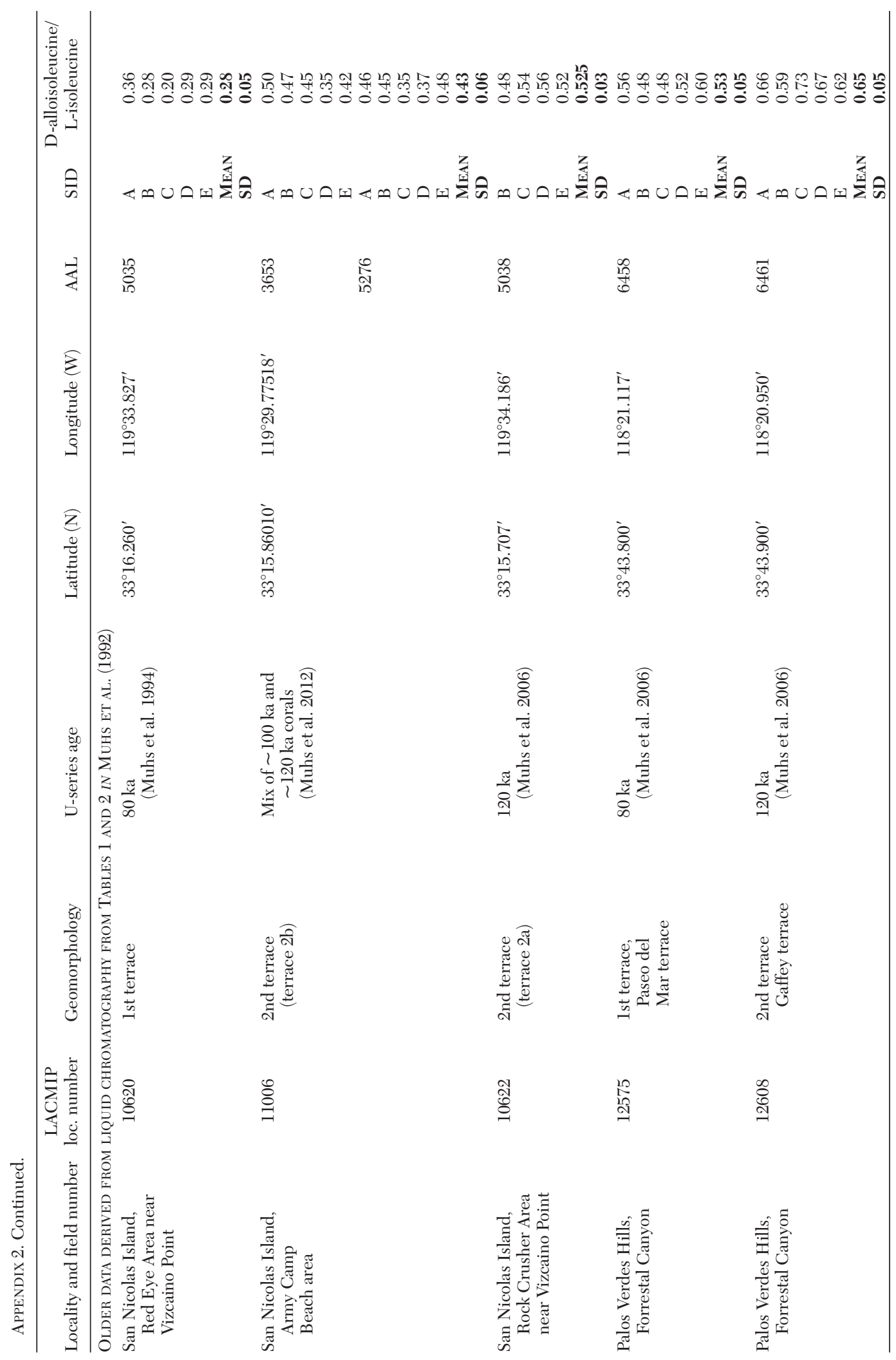




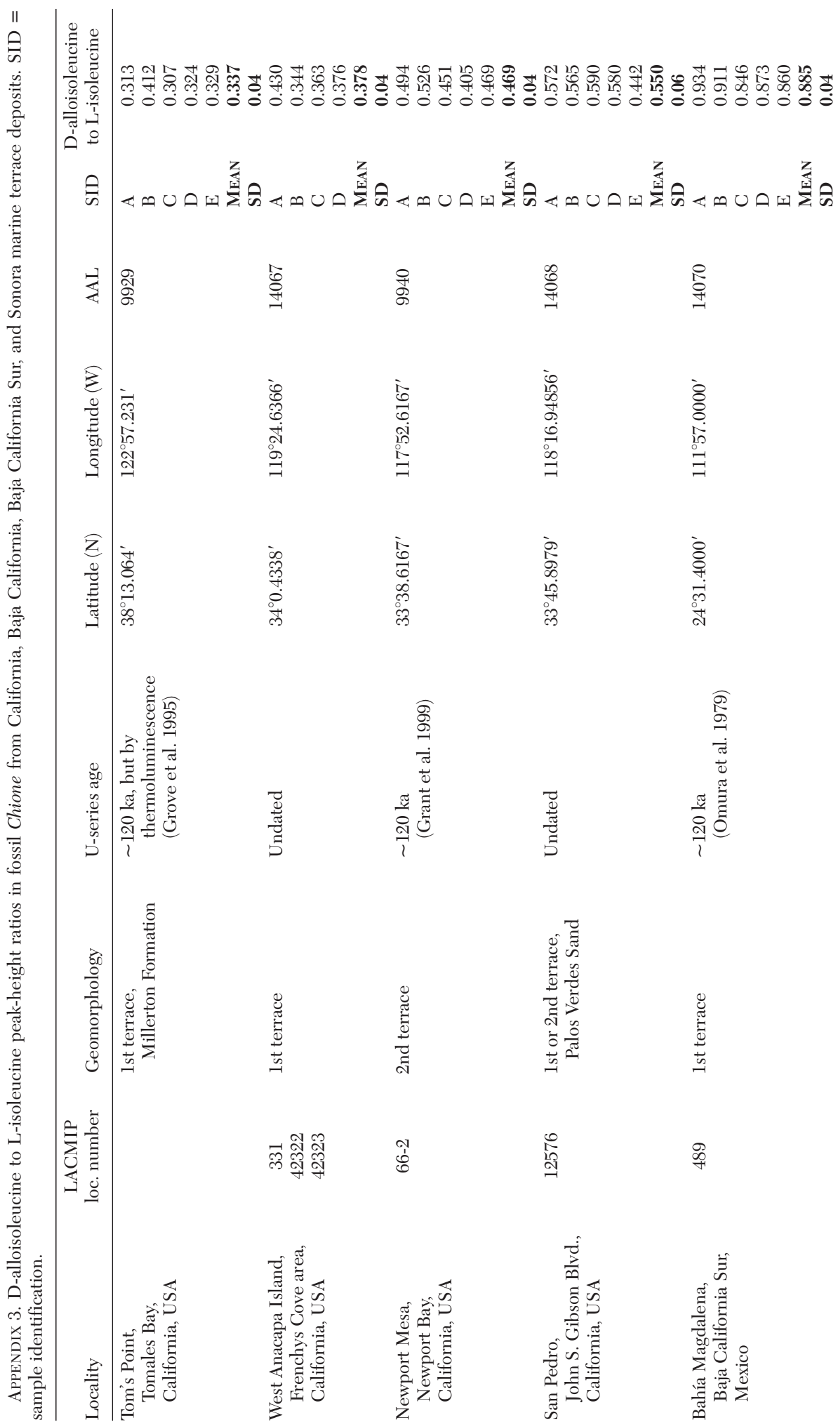



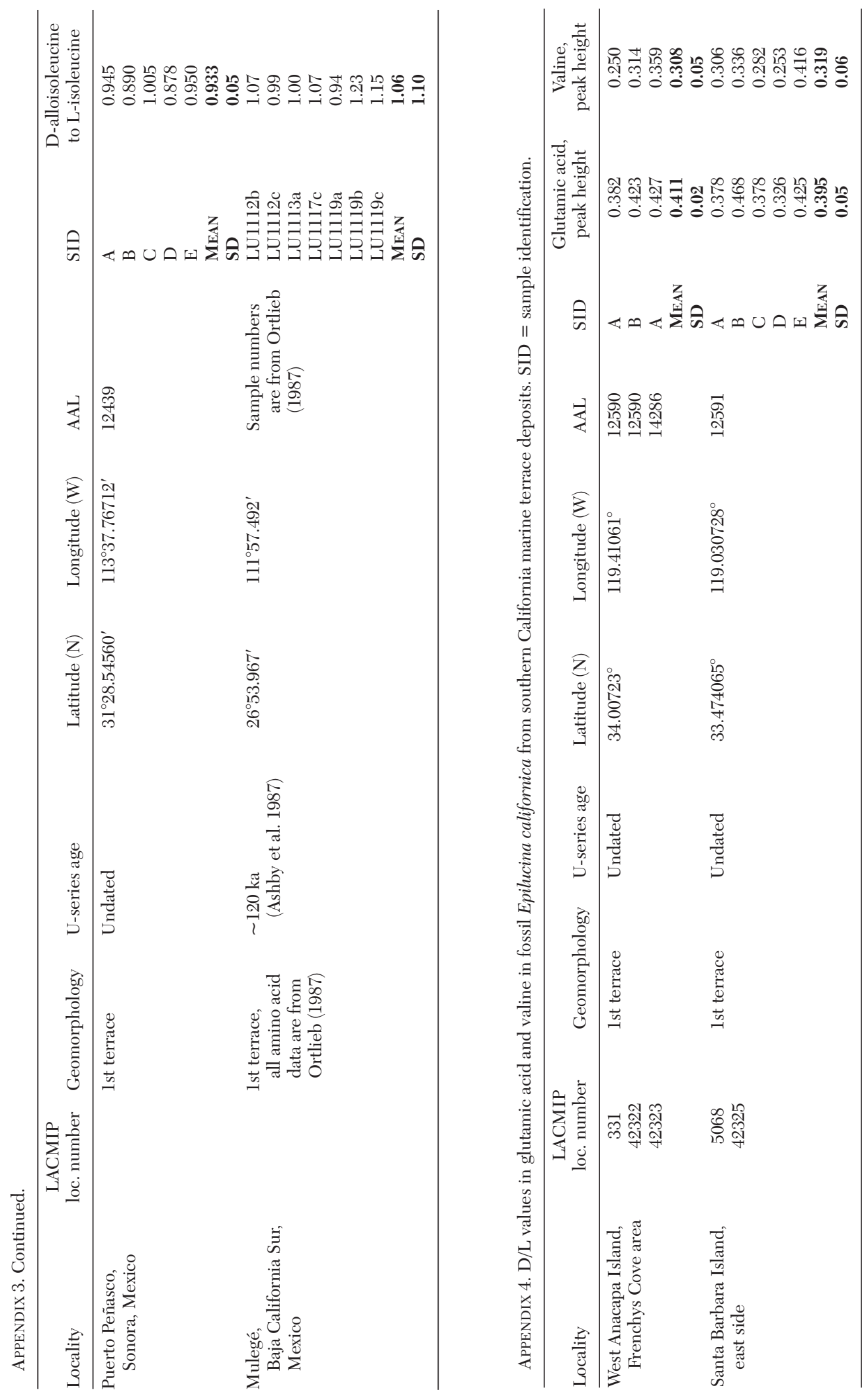